\title{
DIVERSIDAD EN LA DISTANCIA. IMÁGENES ROMANAS DE DIVINIDADES EN EL OCCIDENTE HISPANO
}

\section{Diversity in the distance. Roman divine imagery in the hispanic west}

\author{
THOMAS G. SCHATTNER \\ Instituto Arqueológico Alemán de Madrid
}

Recibido: 08/10/2018

Revisado: 25/03/2019
Aceptado: 29/05/2019

Publicado: 05/07/2019

\section{RESUMEN}

La recopilación de las imágenes de las divinidades del occidente hispánico de índole indígena ofrecen un panorama heterogéneo. Al lado de representaciones como el Endovélico o los demonios de Río Tinto, también se encuentra el dios herrero de Vilar de Perdizes o las creaciones singulares como el así llamado Vestio Alonieco. Con ello queda manifestado que el impulso mediterráneo para la creación de imágenes de divinidades fue acogido de manera distinta y llevó a soluciones diferentes. Su distancia hacia el modelo de la urbs queda pertinente. Pero los monumentos documentan asimismo los inicios de un desarrollo propio en Hispania, que, sin embargo, no acaba imponiéndose a las imágenes de índole greco-romano y por tanto no conduce a un canon propio del occidente indo-europeo hispánico. El ejemplo de Aelio Fronto de Munigua muestra que la iniciativa para la creación de esas imágenes de índole indígena provenía del ámbito privado. Esa iniciativa se ha podido caracterizar dependiendo de la posición social, del grado de cultura, de su procedencia -si es de la capital Augusta Emerita o de la provincia profunda- como muy heterogénea.

\section{Palabras Clave}

Divinidades indígenas; Occidente hispanico.

\section{SumMARY}

The compilation of the images of the native-influenced gods of the Hispanic West leads to a heterogeneous picture. Besides the images that are clearly based on Greco-Roman models such as the Endovellicus or the demons from Rio Tinto there are others that stand in the Celtic-Roman tradition such as the blacksmith-god of Vilar de Perdizes or autochthonous creations such as the so-called Vestius Aloniecus. Thus, the Mediterranean impetus for the creation of divine images was adopted in different ways and led to different solutions. Their distance to the Roman model is evident. Nevertheless, the studied monuments do indeed document the beginnings of an independent development in Hispania, which in a long-term perspective did not prevail against the background of the Roman models, however, and consequently did not lead to a common canon of divine imagery in the Indo-European West of Hispania. The example of Aelius Fronto in Munigua shows clearly that the initiative for the installation of indigenous gods came only by order of the private sphere. Also for this reason it proves to be quite heterogeneous by nature due to the respective social position, level of education and origin - from the provincial capital Augusta Emerita or from the hinterland.

\section{KEY WORDS}

Native-influenced; Gods; Western Hispania.

thomas.schattner@dainst.de 


\section{PreÁmbulo}

Como muy bien ilustra en el catálogo actualizado el sugerente subtítulo "A arte do quotidiano», de Luis Jorge Gonçalves ${ }^{1}$, es cierto que en la estatuaria romana del Occidente hispano están representados todos los géneros: esculturas de bulto redondo y relieves, sarcófagos y escultura arquitectónica ${ }^{2}$. No obstante, su número es reducido y en la mayoría de los casos las piezas están mal conservadas; a menudo son de pequeño formato y no siempre de mármol. Dentro de la categoría de bulto redondo hay retratos, estatuas honoríficas, esculturas de animales y figuras ideales. Tampoco faltan esculturas de los antiguos dioses grecorromanos, la mayoría de Venus, pero también de Asclepio, Cupido y Eros, Harpócrates y Apolo, Minerva, Marte y Dioniso, Ménades, Sileno, Fortuna y Hércules. La iconografía responde al canon grecorromano habitual. Como ejemplo se remite a la musa Melpómene que se conserva en el teatro de Olisipo (Lisboa) (figura 1). En cuanto productos típicos del arte romano, se colocaban casi arbitrariamente tanto en templos y teatros como en santuarios y villas ${ }^{3}$. Estas obras documentan la existencia de imágenes de las divinidades grecorromanas al estilo de Roma. Desde la época julio-claudia, el tipo y la forma pertenecen a la decoración habitual de las ciudades romanas, respondiendo al estándar tal como se conoce en las provincias del imperio romano. Las referencias a importaciones son escasas; tan solo están documentadas en Augusta Emerita, la capital de la provincia de Lusitania ${ }^{4}$. La gran mayoría de las imágenes de deidades que se han conservado se esculpieron in situ siguiendo la iconografía romana convencional. Un mapa de distribución de los hallazgos mostraría

1 Gonçalves, 2007; resumen anterior en CSIR Portugal 1990. - De un modo general agradezco a mis colegas y amigos Michael Blech (Bad Krozingen) y Aquilino Delgado Domínguez (Río Tinto) sus consejos y sugerencias.

2 En el presente artículo se entiende por occidente hispano sobre todo la parte occidental de la Península ibérica, que hoy ocupan Portugal y Galicia. Este territorio pertenece a la ampliación del oeste que la indogermanística ha realizado basándose en criterios lingüísticos, $\mathrm{v}$. al respecto Untermann, 1961 y Untermann, 1975, 77 mapa 4. Si los criterios lingüísticos se sustituyen por criterios arqueológicos, se obtiene un cuadro diferente, v. Schattner, 2015.

3 Kunze, 2008, 106 s.

4 Trillmich, 1990, 316, lám. 29. En Augusta Emeri$t a$ se ha documentado la existencia de un taller que trabajó también en la construcción de grandes obras romanas de la casa imperial en Leptis Magna, Cerveteri, Baiae, etc., v. Trillmich, 1994, 85.

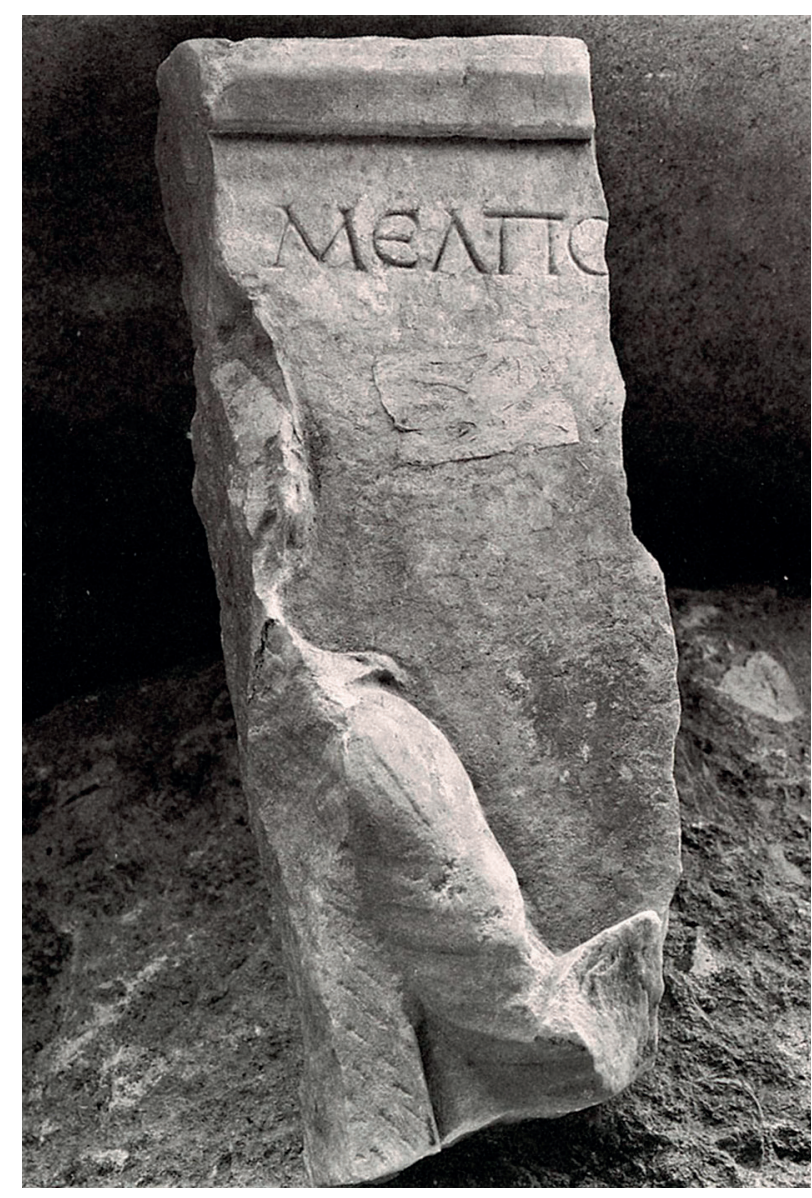

Fig. 1. Lisboa, teatro romano. Relieve de la musa Melpómene. (Fig. 1 Inst.-Neg. DAI Madrid R 171-68-4 (Friedrich))

notablemente menor al norte. De hecho, el valle fluvial puede considerarse una frontera cultural ${ }^{5}$. Según la interpretación usual, nos encontramos ante un arte romano-provincial, entendido como un arte que se practicaba en las provincias del imperio sobre la base de modelos de Roma y sus manifestaciones iconográficas, pero que al mismo tiempo tomaba en consideración y ponía en valor el propio concepto de lo provincial tanto en el ámbito público como privado ${ }^{6}$.

Junto a estas creaciones del arte provincial romano, el Occidente hispano produjo también otras esculturas exentas o en relieve que formalmente podrían adscribirse sin más al canon grecorromano.

5 Schattner, 2015.

6 Definición según Balil Illana, 1960, 108, de acuerdo con Vedder, 2001, 11; Fischer, 2001; Fischer, 2010. Sobre estatuas importadas o griegas en Hispania en general, v. Rodà, 1990 y Rodríguez Oliva, 1996, 15. 
No obstante, por su iconografía, sus inscripciones y/o el contexto arqueológico pueden calificarse, con motivos fundados, como imágenes de divinidades $\mathrm{y}$, atendiendo a su datación, romanas, a pesar de que con frecuencia tienen nombres locales. El número de obras de estas características es escaso ${ }^{7}$. La investigación está de acuerdo en que, en este caso, la creatividad artística local se vio sumida en un conflicto provocado por la presión de la escultura romana que desembocó en soluciones propias. Atendiendo a las características que esporádicamente se intuyen como foráneas, estas obras destacan por su carácter específicamente autóctono. Con todo, y de acuerdo con la definición precedente, estas esculturas deben considerarse también romano-provinciales, ya que la definición debe interpretarse ante todo de manera cronológica, lo que en el contexto que nos ocupa afecta a la estatuaria creada durante el periodo de tiempo en el que Roma estuvo presente en las provincias, incluyendo por tanto no solo en desviaciones estilísticas, sino también temáticas $^{8}$. En el presente artículo se estudiarán en detalle las imágenes de divinidades que se diferencian de las citadas al principio en que no siguen necesariamente modelos romanos, sino que reflejan ideas regionales propias, y en las que las diferencias en la representación quizá obedezcan a una conciencia prerromana y a una tradición más antigua. El enfoque elegido es la identificación del problema con ayuda de ejemplos prácticos capaces de poner de manifiesto, de un lado, la cercanía y, de otro lado, tanto la distancia en cuanto al contenido como la distancia formal frente al arte romano.

La presencia del arte romano provincial en los dos grupos de monumentos citados ${ }^{9}$, es un fenómeno que se da también en otras provincias del Imperio romano, por ejemplo en Germania. La tendencia general apunta a que la corriente basada en modelos romanos acabó imponiéndose a lo largo del tiempo.

7 Bouza Brey, 1944, 206; Cerrillo y Cruz, 1993, 170. El número de ejemplos comentados en este artículo se acerca bastante a los monumentos que se conservan en la actualidad. J. de Alarcão ha relacionado el escaso número con la afirmación tan a menudo repetida de Estrabón de que los galaicos eran ateos (III, 4,16 ) y por eso no tenían templos ni dioses con figura humana (Alarcão, 1974, 91).

8 León Alonso, 1981, 347; Cerrillo y Cruz, 1993, 163; Rodríguez Oliva, 1996; 14; Rodríguez Oliva, 1998, 323.

9 Así opinó ya Balil Illana, 1960, 107-119; León Alonso, 1981, 347 ("dualidad de corrientes artísticas»); Rodríguez Oliva, 1996, 14; y Rodríguez Oliva, 1998, 323 («lenguaje artístico bilingüe»).
Ambas corrientes coexistieron en la época imperial temprana ${ }^{10}$, si bien en Hispania se produjo un desfase cronológico según la parte del territorio de que se tratara, debido al distinto grado de romanización artística, concepto que en este caso debe entenderse en sentido estricto ${ }^{11}$.

Al analizar cada una de las obras, intentaremos averiguar los motivos que llevaron a realizar un monumento en un lenguaje formal $\mathrm{u}$ otro. Asimismo, atendiendo a las peculiaridades de la obra, se estudiará la cercanía formal con alguno de los círculos artísticos prerromanos $\mathrm{y}$, por último, se abordará la relación con la divinidad y el fundamento de la datación.

En lo que atañe al planteamiento, el Occidente hispano al norte del Tajo constituye un campo de investigación idóneo, ya que entró en estrecho contacto directo con la cultura romana y sus imágenes bastante tarde, una vez finalizadas las guerras cántabras (26-19 a. C.) $)^{12}$. Por este motivo, en Occidente se mantuvieron las tradiciones autóctonas de forma notablemente más clara hasta la época imperial ${ }^{13}$. Por el contrario, en el este hispano, que entró enseguida en contacto con el mundo romano, siendo una de sus manifestaciones la adopción del latín como lengua hablada y escrita ${ }^{14}$, el proceso de romanización comenzó muy pronto. De ahí que los habitantes indígenas de esta zona utilizaran nombres de dioses romanos cuando algún tiempo después empezaron a escribirlos en los monumentos, casi siempre aras funerarias o votivas. De hecho, apenas se conoce algún nombre de los antiguos dioses ibéricos ${ }^{15}$. En el oeste, en cambio, los nombres de las divinidades locales seguían utilizándose cuando en el curso del siglo I d. C. -siguiendo la moda roma-

10 Cardozo, 1973, 158, en cambio, parte de un orden cronológico y defiende que la escultura de Roma reemplazó a una escultura más antigua con rasgos indígenas.

11 Por ejemplo, en la Bética en la época republicana tardía: León Alonso, 1981, 347; Rodríguez Oliva, 1996, 14. O en Gallaecia ya entrada la época imperial, v. Acuña Castroviejo y Rodríguez García, 2000, 197.

12 Resumen de las distintas tradiciones prerromanas en la plástica y la escultura de Occidente en Cerrillo y Cruz 1993, 160-164.

13 Schattner 2013a, 393 s.

14 Resumen en Beltrán Lloris, 1995 y Beltrán Lloris 2012.

15 Dea Caelestis: Rodríguez Oliva, 1996, 17 s. Fig. 3; Rodríguez Oliva, 1998, 322; González Alcalde, 1997, 332; Betatun: Corzo Pérez, Pastor Muñoz y Stylow 2007. Sobre los nombres de los dioses ibéricos, recientemente Vidal, 2016. 
na ${ }^{16}$ - se impuso cada vez más la tendencia a rotular los monumentos con inscripciones como forma de expresión ${ }^{17}$, lo que explica que se conservan centenares. Junto a los nombres de los dioses, en algunos monumentos se reproducían también escenas que, de acuerdo con el uso de la escritura, cronológicamente pertenecen a la época imperial, ya que dicho uso marca un terminus post quem en el Occidente hispano, sobre todo en el noroeste ${ }^{18}$. Esta datación deja claro que las imágenes en cuestión pertenecen a divinidades de la época romana.

El problema ha sido estudiado de diversa forma desde el punto de vista regional. Precisamente, los monumentos occidentales han sido descritos aplicando este criterio ${ }^{19}$. Los ejemplos que constituyen el centro del presente estudio proceden de Louri- cripciones de los monumentos estudiados ${ }^{20}$. En la tabla 1 se recogen los monumentos mencionados. La selección pone de manifiesto tanto la difusión geográfica del fenómeno en la totalidad del Occidente hispano (figura 2), como la extensión de las posibilidades de combinación en lo que atañe a los nombres de las divinidades y la correspondiente representación formal o motívica (tabla 1). En ella se refleja claramente que para la creación de la imagen de cada una de las deidades existía otra combinación posible, lo que, a su vez, daba lugar a un paisaje artístico diferente. Como consecuencia de todo ello, las representaciones de las divinidades del Occidente hispano ofrecen una imagen en la que la distancia respecto de la idea de Roma varía más o menos en unos casos que en otros.

\begin{tabular}{l|c|l|l}
\hline $\begin{array}{l}\text { NOMBRE } \rightarrow \\
\text { FORMA } \rightarrow \text { PAISAJE ARTísTICO }\end{array}$ & $\begin{array}{l}\text { NOMBRE INDÍGENA DE LA } \\
\text { DEIDAD }\end{array}$ & $\begin{array}{l}\text { NoMBRE DE } \\
\text { LA DEIDAD EN } \\
\text { LATÍN }\end{array}$ & $\begin{array}{l}\text { NoMBRE DE LA DEIDAD } \\
\text { DESCONOCIDO }\end{array}$ \\
\hline indígena ‘galaico` & Vestius Aloniecus & Dis Pater & Dios herrero (¿Sucellus?) \\
\hline indígena ibero-celta-romano & & & Demonios \\
\hline imagen grecorromana & Endovellicus & & \\
\hline
\end{tabular}

Tab. 1. Posibilidades de combinación de nombres y formas

zán/Vestius Aloniecus, Vilar de Perdizes/dios herrero de nombre desconocido, São Miguel da Mota/ Endovellicus, Munigua/Dis Pater y Río Tinto/ demonios sin nombre (figura 2). El hecho de que se trate de dioses masculinos confirma la idea de que en el Occidente hispano predominan con mucho las divinidades masculinas, tal como reflejan las ins-

16 De hecho, la cultura romana era ante todo «une civilisation d'épigraphie»: Robert, 1961, 454 y MacMullen 1982, 233-246.

17 Schattner, 2019.

18 En el Occidente hispano, la escritura no se introdujo hasta la época imperial, diferenciándose un primer impulso en la época de Augusto, que tiene su reflejo en inscripciones oficiales de Roma, y una segunda oleada en época flavia, cuya mejor expresión se encuentra tanto en monumentos privados como en aras funerarias y votivas, cf. Díaz y Díaz, 1983, 285 s.; Pereira Menaut, 1995, 293; y Schattner, 2019.

19 Península ibérica: Balil Illana, 1960, 120-131; Balil Illana, 1978; Balil Illana, 1979a; Balil Illana, 1979b; Balil Illana, 1981; Balil Illana, 1982; Balil Illana, 1983. Sur de España/ Bética: León Alonso, 1981; Rodríguez Oliva, 1996. Extremadura: Cerrillo y Cruz 1993. Lusitania meridional: Cardozo, 1973. Gallaecia: Acuña Castroviejo, 1974; Balil Illana, 1974; y Calo Lourido, 1994.
De este modo, no solo tenemos ante los ojos la asimilación o, en su caso, el grado de integración de los modelos grecorromanos habituales, sino también los de origen galaico, ibérico-romanos y quizá incluso celtas ${ }^{21}$. Mientras que en los relieves de Lourizán y Vilar de Perdizes se desconoce el contexto del hallazgo, no ocurre lo mismo con las imágenes exentas de São Miguel da Mota, Munigua y Río Tinto, cuyo contexto se conoce muy bien e incluso puede des-

20 En el este hispano la situación es la contraria, cf. Gusi Jener 1997, 201; Schattner, 2013 a, 393. En el noroeste hispano se conocen las siguientes imágenes de divinidades femeninas: estatuilla de una diosa de la fertilidad (Rodríguez Colmenero 1991a, 157 y Rodríguez Colmenero 1993, 440 s.), la llamada Venus de Sendim (Rodríguez Colmenero 1993, 442; Silva 2007, 425 s. n. ${ }^{\circ} 584$ lám. 126,2; y Rodríguez Colmenero, 1991b, 45 Fig. 53), la llamada Venus de Briteiros (Cardozo, 1971, 143 n. 84 y Rodríguez Colmenero, 1993, 444) y quizá una de las estatuas sedentes del entorno de Orense (Rodríguez Colmenero, 1977, 325 s; y Rodríguez Colmenero, 1993, 446-449).

21 Sucellus es celta, v. LIMC VII 2 (1994) 820 (Nagy). En cuanto a esculturas exentas de caballos solos en santuarios se conocen ejemplos de yacimientos celtas; v. abajo el capítulo sobre Dis Pater. 


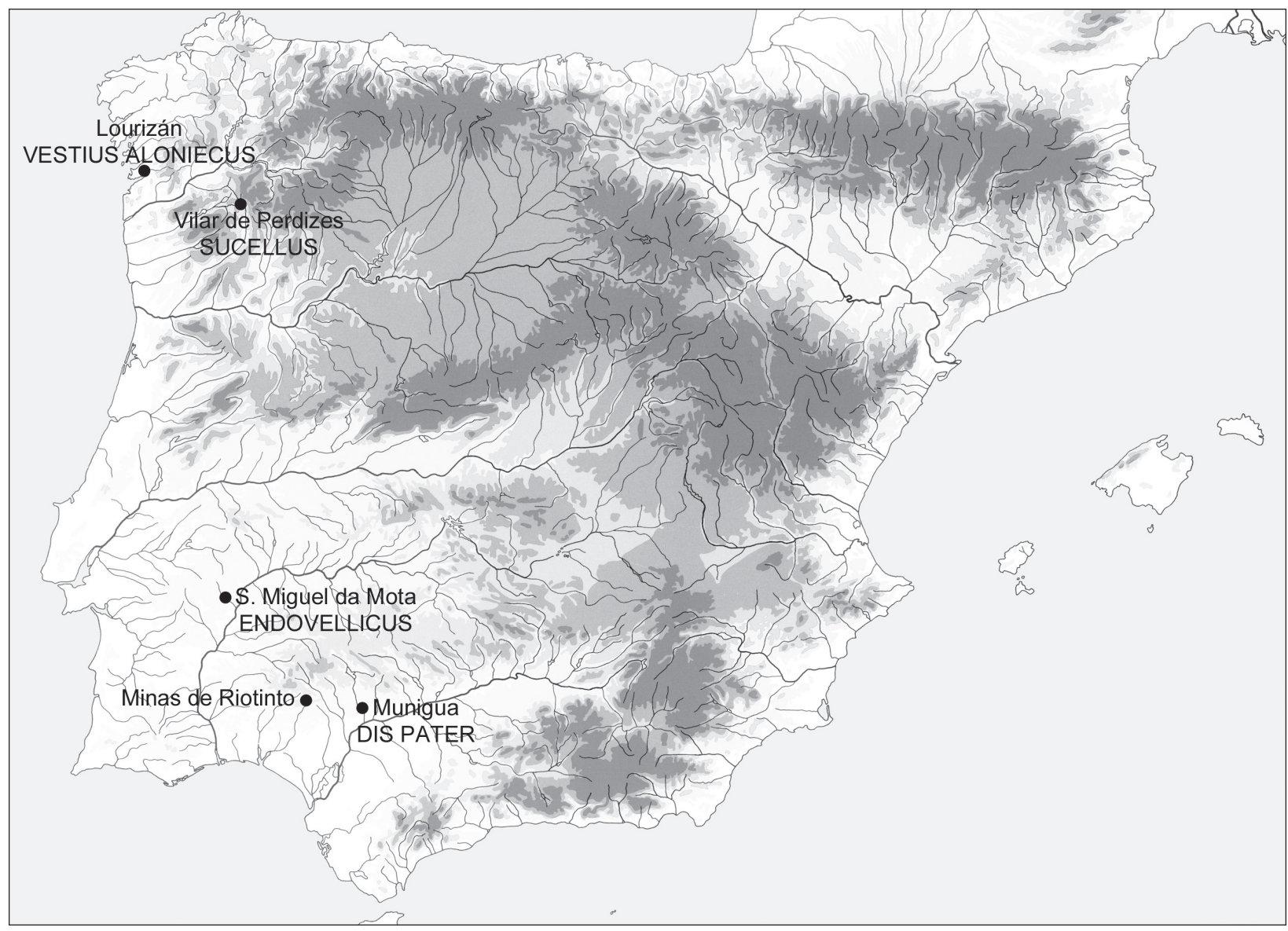

Fig. 2. Localización de los monumentos estudiados en el presente artículo. (Fig. 2 DAI Madrid, montaje E. Puch Ramírez)

cribirse en detalle. Con la excepción del Sucellus de Vilar de Perdizes, cuya imagen responde a la tradición iconográfica habitual, muy difundida, por otra parte, en las provincias septentrionales del imperio romano, en los demás casos se trata probablemente de imágenes singulares, es decir únicas, de las divinidades citadas. En el curso del análisis de los ejemplos se demostrará si procede o no utilizar el concepto de imagen de culto. De momento, nos ocuparemos de los aspectos formales y dejaremos para más adelante las cuestiones conceptuales.

\section{ICONOGRAFÍA}

Vestius Aloniecus de Lourizán (figura 3a y b) El relieve del llamado Vestius Aloniecus procede de Lourizán, provincia de Pontevedra (Galicia), y se descubrió reutilizado en diferentes construcciones, fuera de su contexto original22, por lo que

22 Bouza Brey, 1944, 204; Calo Lourido, 1991; Alfayé cabe clasificarlo como expolio o hallazgo disperso. En las inmediaciones se encontraron tres aras votivas; dos de ellas contenían sendas inscripciones de la misma donante, Severa ${ }^{23}$, y el nombre de Vestius Aloniecus $^{24}$, divinidad desconocida hasta ese momento, con el que desde entonces y hasta hoy en día se identifica el relieve con la imagen del dios ${ }^{25}$.

Villa, 2013, 193-195. La bibliografía más antigua en Alfayé Villa, 2013, 194, nota 10.

23 Tranoy, 1977, 225 afirma, citando ejemplos, que en Galicia no era extraño que con cierta periodicidad un mismo donante dedicara dos o más altares de tamaño y forma similares. Blanco Freijeiro, 1962, 41, destaca la frecuencia del nombre en las inscripciones del siglo III d. C.

24 Sobre las inscripciones CIRG II, 107; IRG III, 27; AE 1950, 22; CIRG II, 108; IRG III, 28; AE 1950, 23; Blázquez Martínez, 1970, 67 s. Fig. 21. 22.

HEsp http://eda-bea.es/pub/list. php?refpage $=\% 2$ Fpub\%2Fsearch_select. php\&quicksearch=Vestio+Alonieco (consulta del 11.8.2017).

25 Bouza Brey, 1944, 201-206, lám. 35-37; Carballo 1948, 18 s. Fig. 2; López Cuevillas, 1951, 193; López Cue- 

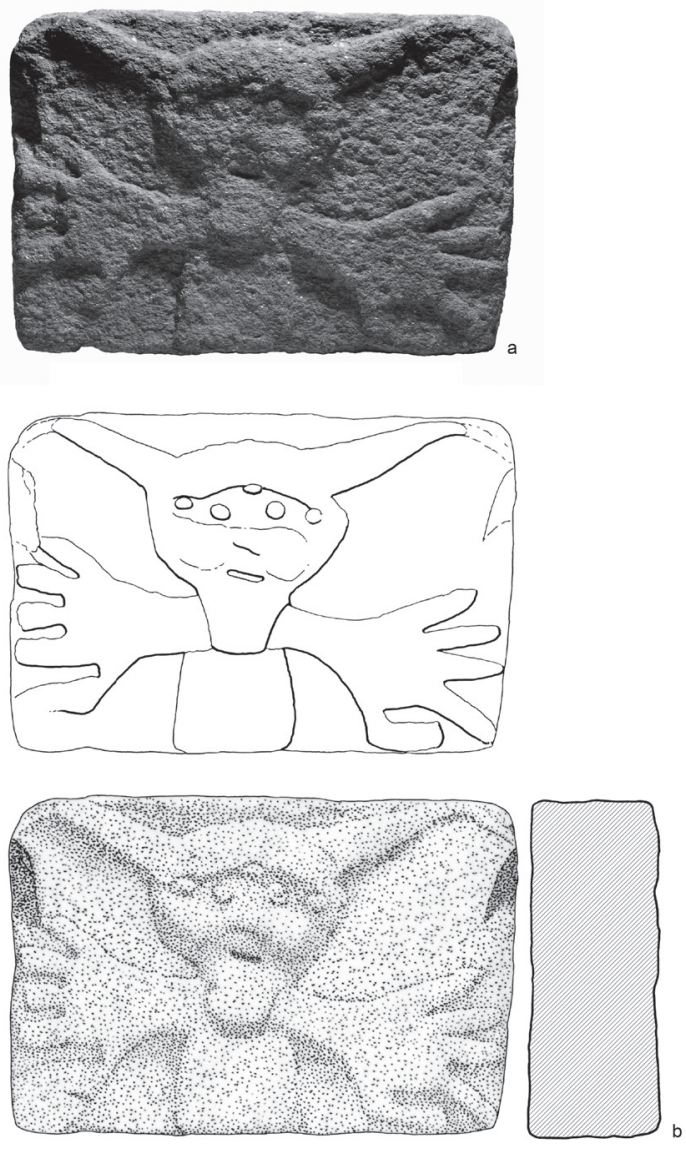

$50 \mathrm{~cm}$

Fig. 3 a. b. Lourizán. Friso con la imagen del llamado Vestius Aloniecus. (Fig. 3 a Patterson b D-DAI-MADA-63-Z-3-2017-FER)

No obstante, la vinculación de la inscripción con la imagen no es segura al cien por $\operatorname{cien}^{26}$, por lo que atendiendo a motivos metodológicos se sitúa bajo reserva. Según parece, la investigación acepta en general la datación en el siglo II d. C, que es la que se menciona en la primera publicación ${ }^{27}$; la calidad de ejecución del relieve no es muy buena.

villas, 1953, 371; Blázquez Martínez, 1962, 101; Blázquez Martínez, 1975, 181 Fig. D en pág. 83; López Monteagudo, 1977, 191 s.; López Cuevillas, 1979, 473; Tranoy, 1981, 290 s.; Rodríguez Colmenero, 1993, 445; Calo Lourido, 1993/94, 97; Calo Lourido, 1994, 305-309 nº 43; Araújo, 1999, 250 Fig. 1.

26 Calo Lourido, 1994, 743.

27 Bouza Brey, 1944, 206. Tranoy, 1981, 291, se inclina por una datación anterior en el siglo II/I a. C., mientras Blázquez Martínez, 1975, 182, la sitúa en el siglo III/III d. C.
El relieve muestra el torso de una figura masculina (figura 3 a. b) con los brazos y las manos extendidos lateralmente y los pulgares mirando hacia abajo, de forma que el dorso de las manos está vuelto hacia el espectador ${ }^{28}$. La figura tiene barba y una densa cabellera, de la que a la altura de la frente sobresalen dos protuberancias corniformes que se van afilando hacia los extremos. Asimismo, tiene la boca muy abierta. Desde un punto de vista puramente teórico podría pensarse en la posibilidad de que el relieve tuviera una parte inferior y la figura se mostrara de cuerpo entero o donde figurara una inscripción. Por motivos técnicos puede excluirse semejante posibilidad ${ }^{29}$. Tal como revela la autopsia, el estado del acabado de la superficie es el mismo tanto en la parte inferior y en los demás lados como en la cara visible, es decir, la parte inferior no fue alisada expresamente ${ }^{30}$. Por ello, no procede sacar otras conclusiones. Las medidas sugieren la identificación con un friso (tabla 2) 31 , en analogía con el friso de Frende (Baião, Portugal), del que se han conservado tres planchas ${ }^{32}$. La observación de estas piezas permite sacar la conclusión de que ambos frisos debieron pertenecer a monumentos de tamaño similar $^{33}$. Por otra parte, esta adscripción a un friso es tan sólida, que la hipótesis que afirma que el relieve de Lourizán sea un monumento independiente y completo no parece plausible. Entre otras cosas, falta el marco habitual, construido, por ejemplo, a base de perfiles, como tienen en general los monumentos de piedra exentos, como estelas o lápidas funerarias ${ }^{34}$. En el friso del que presuntamente for-

28 López Cuevillas, 1953, 371 ("brazos...retorcidos"); Blázquez Martínez, 1957, 42 ("palmas de las manos vueltas").

29 Construcciones semejantes se conocen, por ejemplo, de las estatuas sedentes exentas en las que el tronco se ha esculpido en un bloque y la parte inferior del cuerpo, en otro bloque; v., p. ej., la estatua sedente de Livia en el Museo Arqueológico Nacional de Madrid, v. Ruiz-Nicoli, 2009, 304, lám. 32.

30 En este punto deseo expresar mi gratitud al director del Museo de Pontevedra, Carlos Valle, y también al conservador Antonio de la Peña Santos por haber dado su consentimiento para ver, dibujar y fotografiar la pieza.

31 Las medidas han sido tomadas para Lourizán de Bouza Brey, 1944, 204; para Frende de CSIR Portugal 52 n. ${ }^{\circ} 145$.

32 CSIR Portugal 52, $\mathrm{n}^{\circ}$ 145; Gonçalves, 2007, 447-450 $\mathrm{n}^{0} 231$; recientemente, Schattner, 2012, 411 s., Fig. 5.

$33 \mathrm{La}$ posibilidad de que pertenezcan al mismo monumento puede excluirse dada la distancia de más de $250 \mathrm{~km}$ entre Frende y Lourizán.

34 Los catálogos del CSIR Portugal o Gonçalves, 2007, 
maba parte el relieve, éste ocuparía con gran certeza un puesto central. Prueba de ello es la imagen frontal, a cuyos lados se situarían probablemente otras escenas. En cualquier caso, en el mencionado relieve de Frende, las figuras que representan un baile, una "escena de combate" 35 y una procesión de animales se muestran de perfil; tan solo la figura sentada en el suelo tiene el torso girado de frente. Estamos ante el motivo de Sileno ebrio levantado por sus compañeros, es decir ante una escena mitológica ${ }^{36}$.

Si se tratara de un friso, ¿dónde estaría situado? En el noroeste hispano, los edificios decorados con esculturas son muy escasos. No obstante, en el Monte Mozinho, próximo a la ciudad de Penafiel (Portugal), existió una pequeña construcción, de la que solo se conservan los cimientos de planta rectangular de $3 \times 2,6 \mathrm{~m}^{37}$, que evidentemente tuvo que estar profusamente decorada con esculturas $^{38}$. El edificio, construido enteramente en granito local, está datado en el siglo II d. C. ${ }^{39}$ y en él se han encontrado tres cabezas de bulto redondo, fragmentos de un cuerpo (mano y pie), un torso masculino desnudo, varios fragmentos grandes de la estatua de un caballo (entre ellos, la cabeza y un casco delantero) con su pedestal y el arranque de las patas traseras, así como un relieve de dos caras (pescador/figura femenina con túnica, medidas en tabla 2), una cabeza en relieve, distintos elementos arquitectónicos y fragmentos de columnas acanaladas $^{40}$. De momento no se ha publicado todavía

así lo demuestran.

35 Hasta ahora, la escena se ha interpretado como una lucha. Tranoy, 1981, 354, presumió un combate en el contexto de juegos funerarios; De Souza, en CSIR Portugal $52 \mathrm{n}^{\mathrm{o}} 145$, pensó en una lucha entre gladiadores. De Matos 1995,86 s. $\mathrm{n}^{\circ} 39$, en una gigantomaquia, lo mismo Ribeiro, 2002a, 375, n ${ }^{\circ} 23$; Gonçalves, 2007, 450, $\mathrm{n}^{\mathrm{o}} 231$, en un combate ritual.

36 Véase el paralelismo directo con un ejemplar descubierto en Juliobona/Lillebonne, localidad situada al norte de la Galia (Espérandieu, 1911, 198 s., nº 3115).

$37 \mathrm{La}$ excavación data de 1943 y fue realizada por E. Ferreira de Sousa. Sin embargo, de la excavación solo existen informes preliminares, la publicación definitiva nunca ha visto la luz (Soeiro, 1984, 259). En 1974 se realizó una nueva excavación exactamente en el mismo lugar y, hasta ahora, ha sido la más fructífera en cuanto a hallazgos, v. Almeida, 1974, 6. 9.

38 Soeiro, 1998, 15.

39 Almeida, 1974, 29.

40 Almeida, 1974, 30-34; Soeiro, 1984, 262; Carvalho, 1993/94, 75 s. n. ${ }^{\circ} 22-24$; Soeiro, 1998, 29; Kobusch, 2014, 185. ninguna reconstrucción científica del edificio que incluya los elementos escultóricos. De otra parte, cabe plantearse la pregunta de si todas las esculturas pertenecen realmente a dicho edificio y cuál sería su emplazamiento ${ }^{41}$, en el interior o en su entorno inmediato. Esta pregunta incide a su vez en el problema de que en el castro de Monte Mozinho no se han identificado hasta ahora otros edificios que hubieran podido ofrecer un marco arquitectónico adecuado para colocar las esculturas ${ }^{42}$. De ahí que la función de la construcción rectangular $\mathrm{CVII}^{43}$, que anteriormente se consideraba un templo por su emplazamiento elevado (podio), ahora se ponga en duda ${ }^{44}$. Tampoco está claro el uso dado al edificio pequeño que ocupa nuestra atención. En un primer momento se interpretó como una construcción funeraria, de la que existe una reconstrucción esquemática ${ }^{45}$, pero posteriormente ese uso se puso en tela de juicio porque en las inmediaciones se descubrieron viviendas de distintas épocas ${ }^{46}$, y la coexistencia de zonas residenciales y tumbas era, en general, incompatible ${ }^{47}$. Por esta razón, en la actualidad se habla de un monumento para la glorificación de la soberanía romana ${ }^{48}$, es decir, de un monumento de carácter principalmente político, que por extraña lógica estaría fuera de la ciudad, delante de la puerta de acceso principal ${ }^{49}$. En cuanto a la pregunta planteada con anterioridad, la pequeña construcción del Monte Mozinho -en la reconstrucción de que se trate- demuestra la existencia de edificios en el noroeste hispano que podrían haber estado deco-

41 Kobusch, 2014, 185. Como argumento en su favor, Almeida, 1974, 30, remite al granito usado tanto en el edificio como en las esculturas, que es idéntico en ambos casos. 42 Soeiro, 1984, 266.

43 Almeida, 1980.

44 Soeiro, 1998, 38.

45 Almeida, 1974, 31, Fig. 11; Soeiro, 1984, 266, Fig. 125; Alarcão, 1988, 27, n 466; Kobusch, 2014, 48, 184 cat. 10 supl. 9.

46 Almeida, 1974, 6. 9. Según esta teoría, el edificio se construyó encima de viviendas más antiguas. Los edificios de los alrededores visibles en el plano pertenecen, sin embargo, a la época tardoantigua, v. Soeiro, 1984, 261.

47 Soeiro 1998, 27; Kobusch, 2014, 185, se muestra también escéptico.

48 Soeiro 1998, 29: “...monumento dedicado à gloria e poder de Roma”.

49 El edificio es tan interesante como enigmático, los problemas que plantea merecen un estudio exhaustivo que deberá hacerse en otro momento. 


\begin{tabular}{l|l|l|l}
\hline & $\begin{array}{l}\text { Longitud } \\
\text { cm }\end{array}$ & $\begin{array}{l}\text { Altura } \\
\text { cm }\end{array}$ & $\begin{array}{l}\text { Fondo/grosor del panel } \\
\text { cm }\end{array}$ \\
\hline Frende & 68 a 78 & 45 a 48 & 22 a 27 \\
\hline Lourizán & 66 & 45 & 16 \\
\hline Monte Mozinho & $?$ (roto) & $>64$ & $?$ \\
\hline
\end{tabular}

Tab. 2. Comparación de las medidas de los paneles de los frisos de Frende, Lourizán y Monte Mozinho

rados con relieves como el de Lourizán ${ }^{50}$. También en el caso del friso de Frende, descubierto en el contexto de una necrópolis tardoantigua, se pensó en un monumento funerario, pero quizá se trate de un templo ${ }^{51}$.

Fijémonos en la escena representada. Los relieves con figuras de medio cuerpo son muy escasos en el arte hispano noroccidental, conociéndose muy pocos ejemplares. En primer lugar cabe citar el nicho coronado por un frontón excavado en la pared rocosa de Fonte do Ídolo/necrópolis de Bracara Augusta (Portugal) ${ }^{52}$. Este relieve se encuentra dentro de la tradición de las lápidas funerarias de nicho romanas con retrato, cuyo exponente hispano más representativo se encuentra en la ciudad de Augusta Emerita, capital de la Lusitania, lo que ha sido observado y aceptado con razón desde hace bastante tiempo ${ }^{53}$. En el ámbito de los monumentos romanos de la península, las lápidas emeritenses ocupan una posición singular, ya que, como es sabido, dependían directamente de modelos romanos $^{54}$. En este sentido, la representación de figuras de medio cuerpo, en cuanto motivo, podría estar relacionada con Augusta Emerita, la capital de la provincia, pero también con Roma y, con ello, con el arte romano.

El hecho de que en los nichos de las lápidas emeritenses se represente siempre al difunto $y$, a tenor

50 En la reconstrucción, Almeida, 1974, 32, y Carvalho 1993/94, 82, plantean el citado relieve de Monte Mozinho (pescador/estatua femenina con túnica) como parte de una balaustrada basándose en la altura (v. tabla 2).

51 Resumen actualizado del estado de la investigación en Gonçalves, 2007, 447-450, nº 231.

52 Resumen en Blech, 1993, 362 s.; Gonçalves, 2007, 400-407 n. 199; Garrido Elena, Mar y Martins 2008, 2025, Fig. 14. 16-19. 23. Otras imágenes de medio cuerpo en una estela (¿funeraria?): Gonçalves, 2007, 424, $\mathrm{n}^{\circ} 212$ procedente de Rigueiro dos Mouros/Montalegre (Portugal).

53 Tranoy, 1981; Garrido Elena, Mar y Martins 2008, 57. Otras representaciones, p. ej. de Tajo Montero, v. Blech, 1981; Alonso Rodríguez et al., 2014.

54 Vedder, 2001, 11; Trillmich, 2001, 21. del número de ejemplares conservados procedentes de la capital de la provincia, por analogía debería considerarse argumento suficiente para reconocer en la figura esculpida en la roca de Fonte do Ídolo al difunto en cuestión, en este caso, el donante Celicus Fronto, cuyo nombre aparece en una inscripción ${ }^{55}$. La escena representada en el tímpano del frontón en este caso, una paloma y un martillo- resulta, sin embargo, inusual en el contexto provincial. En las lápidas emeritenses el tímpano suele ser a menudo demasiado pequeño, por lo que, en general, se deja vacío o si hay espacio suficiente, se decora con un rosetón o un elemento similar ${ }^{56}$. En Italia y, sobre todo en Roma, el tímpano es notablemente mayor, por lo que la decoración escultórica es más frecuente ${ }^{57}$.

En cuanto a la interpretación tanto del nicho como del retrato, Jorge de Alarcão ha aportado una idea $^{58}$, recogida y desarrollada por Alain Tranoy ${ }^{59}$. Su hipótesis generó una dinámica propia y tuvo también sus seguidores. La idea se basa en una separación conceptual arbitraria del personaje representado en el nicho y las esculturas del tímpano ${ }^{60}$. De acuerdo con su teoría, Tranoy reconoce en la figura humana al donante, mientras que la paloma y el martillo del tímpano los considera atributos no

55 Descifrado por primera vez por Blázquez Martínez, 1962, 196. Coinciden Tranoy, 1981, 283; da Silva, 1986, 297; CSIR Portugal, 1990, 68; y Carvalho, 1992, 132. En contra de ello y en favor de la representación de una divinidad se han manifestado Vasconcellos, 1905, 259; Alarcão, 1974, 94; Alarcão, 1988, 96; Rodríguez Colmenero, 2002, 27; Olivares Pedreño, 2002, 221 y recientemente Garrido Elena, Mar y Martins 2008, 57. Una reciente exposición recopilatoria de la historia de la investigación en Gonçalves, 2007, 400-407, nº 199; Garrido Elena, Mar y Martins, 2008, 29-38.

$56 \mathrm{El}$ ara votiva de Valeria Avita, Vedder, 2001, 121, $\mathrm{n}^{\mathrm{Q}}$ cat. 2, lám. 25, decorado con una cabeza de carnero como símbolo de los taurobolios, constituye una excepción.

57 Recopilación de los monumentos en Kleiner, 1987.

58 Alarcão, 1988, 96.

59 Tranoy, 1981, 283-285.

60 Olivares Pedreño, 2002, 222-227; Garrido Elena, Mar y Martins, 2008, 37. 
del personaje representado en el relieve, sino de la diosa Nabia, documentada epigráficamente en un pequeño ara descubierto en las inmediaciones ${ }^{61}$. Esta teoría dio lugar a un intrincado entramado de ideas que se fue complicando cada vez más hasta desembocar en correlaciones y transversalidades aparentemente confusas entre las inscripciones y las imágenes de las figuras representadas ${ }^{62}$.

En este contexto cabe recordar que en las lápidas de Roma, la persona representada en el nicho era siempre el difunto. En el tímpano rara vez se representaban objetos identificables como atributos. Con todo, esta descripción es válida solamente para un reducido número de monumentos. Mucho más frecuente es el modelo en el que el frente está ocupado en su totalidad por la inscripción, por lo que no queda espacio para la figura del difunto, al que se representa en el tímpano en forma de prótomo, bien de medio cuerpo o de cuerpo entero ${ }^{63}$. Heráldicamente, dos palomas a ambos lados de un trípode con carácter de atributo aparecen solamente en el tímpano del ara de Lucius Postumus Iulianus ${ }^{64}$. Esta singularidad es claramente un indicio de la construcción del altar según un proyecto individual. En estos casos, las figuras u objetos guardan claramente relación con características o particularidades del difunto ${ }^{65}$. En el caso del ara de Lucius Postumus Iulianus, los pájaros debieron tener mucha importancia para él, ya que aparecen representados de forma distinta con mucha frecuencia; según la descripción del catálogo, el motivo de los pájaros aparece en no menos de 13 ocasiones $^{66}$. Incluso cuando se representan atributos relacionados habitualmente con divinidades, éstos aluden a alguna relación del difunto con la divinidad de que se trate. Así, el carcaj y el arco, de un lado, y la cornucopia, la antorcha, el remo y la rueda, de otro lado, son atributos de Diana y Fortuna, respectivamente, dos diosas a cuyos atributos -en este caso indicados mediante los objetos citados- se remiten la difunta Cornelia Tyche y su hija Iulia ${ }^{67}$. No obstante, los atributos no convierten a las representadas en diosas.

61 Recientemente Garrido Elena, Mar y Martins 2008, 25 s., Fig. 22.

62 Exposición resumida en Garrido Elena, Mar y Martins 2008, 33-38.

63 P. ej. Kleiner, 1987, lám. 60, nº 105. 106; lám. 62, nº 111; lám. 63, nº 112.

64 Kleiner, 1987, 175-177, nº 53, lám. 33,2.

65 Kleiner, 1987, $29 \mathrm{s.}$

66 Kleiner, 1987, 176.

67 Kleiner, 1987, 253-256 n. 113 lám. 63,3.
En lo que atañe al relieve del nicho de Fonte do Ídolo, las explicaciones anteriores significan que las aves y el martillo del tímpano hacen referencia únicamente a Celicus Fronto, el donante ${ }^{68}$. La interpretación específica de la paloma escapa a nuestro conocimiento. El motivo en sí aparece también en lápidas romanas, como ha quedado indicado. El martillo remite a Celicus Fronto en cuanto constructor y donante, tal como reza la inscripción: CELICVS FECIT ${ }^{69}$, como ya supuso Vasconcellos ${ }^{70}$.

Otra figura de medio cuerpo es la conocida como Herma de Seixabre ${ }^{71}$, si bien no sirve directamente como elemento de comparación de escultura de bulto redondo, ya que es de tipo Jano y, por tanto, pertenece a otro género escultórico.

Tomando en consideración las reflexiones precedentes, en el caso del relieve con la figura de Vestius Aloniecus (figura $3 \mathrm{a} . \mathrm{b}$ ) podemos decir lo siguiente a modo de resultado intermedio:

- la imagen de medio cuerpo puede haber sido tomada directa o indirectamente del arte funerario hispano, en concreto del emeritense. Entre los hallazgos arqueológicos no hay ninguna fuente gráfica, por ejemplo, frisos arquitectónicos, que pudieran haber servido de modelos.

- en el acto de la recepción debió producirse una reinterpretación en el sentido de que el busto no representaba ya a la persona fallecida, sino a una divinidad.

- en la composición formal de la imagen de la deidad se aplicaron ideas locales propias, tal como se demostrará en lo que sigue.

Ahora bien, ¿de qué dios se trata? La investigación ha centrado la atención desde el primer momento en las dos prolongaciones puntiagudas que se han interpretado como cuernos ${ }^{72}$, lo que le ha

68 Como muy acertadamente ha observado Blech, 1993, 362 , la figura de pie representa a una mujer, que atendiendo al cuerno de la abundancia solo puede tratarse de Fortuna. Siguiendo a Colmenero, 2002, 27 (más bibliografía), esta figura se relaciona con el altar de Nabia. De ser así, el dios Tongoenabiagus carecería de imagen.

69 Garrido Elena, Mar y Martins 2008, 22, inscripción $\mathrm{n}^{\mathrm{0}} 2$. Sus sucesores destacan la actividad constructora:....RENOVARVNT, v. Garrido Elena, Mar y Martins 2008, 24, inscripción $\mathrm{n}^{\mathrm{0}} 6$.

70 Vasconcellos, 1905, 261.

71 González Ruibal, 2003, 163, Fig. 6. A este contexto pertenece sin duda el llamado "monumento antropomorfo" de Pueblanueva/Toledo, v. Abascal y Alföldy 2015, 145, Fig. 134, que, sin embargo, no está datado.

72 Blanco Freijeiro, 1949, 429-431. 
llevado a equiparar la figura con diversos dioses del panteón grecorromano, en concreto, con Ares $^{73}$ y con Cernunnos ${ }^{74}$. También, al revisar las imágenes de los dioses provinciales romanos se aprecia que, en algunos casos, las alas del pétaso de Mercurio parecen cuernos ${ }^{75}$, pensándose también en un Mercurio psicopompo ${ }^{76}$. Sin embargo, los cuernos no son la única característica destacable del llamado Vestius Aloniecus. A ellos se añaden la boca abierta y los brazos extendidos con los dedos de las manos separados. La combinación de las prolongaciones corniformes y el gesto que provoca la boca abierta aparece también en el capitel de una pilastra de Lausana (Suiza) que se interpreta como un demonio (¿sátiro?,¿Pan? ${ }^{77}$. Los brazos extendidos lateralmente con los dedos de las manos separados se dan asimismo en las imágenes de Perseo-Andrómeda ${ }^{78}$ y en relieves metrológicos. Pero estos dos paralelismos no se sostienen. En estos últimos, el motivo aparece solamente en ejemplares griegos ${ }^{79}$, mientras que en el otro ejemplo, la feminidad de Andrómeda y su representación encadenada hablan en contra de la citada relación ${ }^{80}$. Tampoco convence el ejemplo aportado a la discusión por F. Benoît ${ }^{81}$, esto es, la figura representada en un ladrillo tardoantiguo de Roussas (Drôme) ${ }^{82}$ : de un lado, porque se trata de un jinete, que, en cuanto motivo, pertenece al círculo de las representaciones de Epona y, por otro, porque solo tiene una mano extendida, tratándose por tanto de un gesto deíctico con un significado distinto.

Ninguna de las explicaciones aportadas hasta ahora se ha detenido en las manos giradas con los pulgares señalando hacia abajo, que siguen sien-

73 Blanco Freijeiro, 1957, 516.

74 Blázquez Martínez, 1957, 42; Tranoy, 1981, 291.

75 Ejemplos: Espérandieu, Recueil VII (1918), $198 \mathrm{n}^{\mathrm{Q}}$ 5591; VIII 2 (1922), 86 s., nº 6009 (de Unterhambach). Sobre las transformaciones de Mercurio en el contexto provincial romano de la Galia v. Boucher, 1983, sobre todo 427, Fig. 16, y Marco Simón, 2003, 129, Fig. 5.

76 Benoît, 1959, 165, nota 134; Calo Lourido, 1991, 114; Calo Lourido, 1993/94, 97; Calo Lourido, 1994, $743 \mathrm{~s}$.

77 Espérandieu, Recueil VII (1918), 84, n² 5384; CSIR Suiza, 2002, 68 s., $\mathrm{n}^{\mathrm{Q}} 40$ lám. 36 y frontispicio.

78 En el contexto provincial romano de la Galia s. Espérandieu, Recueil I (1907) 22, $\mathrm{n}^{\circ} 17$ de Brigantio/Briançon.

79 Griego Wesenberg, 1975/76; Romano Ioppolo, 1967, 90, Fig. 1.

80 LIMC I, 1 (Zúrich y Múnich 1981), 776-780 (Schauenburg).

81 Benoit, 1959, 165, nota 134.

82 Benoît, 1954, 27-29, lám. 1,2. do un enigma. La sin duda caricaturesca figura evoca un demonio, lo que unido a la calidad de la ejecución hace innecesaria extender la búsqueda a ámbitos elaborados del arte romano, tales como imágenes teomorfas de gobernantes ${ }^{83} \mathrm{o}$ a otras representaciones de deidades, como Sol ${ }^{84}$. Mucho más prometedora parece en cambio la revisión de las esculturas ibéricas. El llamativo tamaño de las manos del llamado Vestius apunta en esa dirección, pues esa es precisamente una característica de las estatuillas ibéricas ${ }^{85}$. Los brazos y las manos extendidos aparecen allí en conexión con las representaciones de Potnia hippon; la diosa extiende los brazos (en ángulo) y las manos hacia los dos caballos ${ }^{86}$. Una estatuilla de bronce de Sagunto presenta también los cuernos típicos de las imágenes de los sátiros ${ }^{87}$, apuntando así a un sincretismo romano-ibérico que habría podido influir asimismo en la creación de la figura de Vestius, si bien tampoco en este caso existe un paralelismo convincente.

A modo de resumen cabe decir que la investigación ha puesto de manifiesto analogías y paralelismos puntuales que, cada uno por sí mismo, explican, más o menos, algunos detalles del llamado Vestius Aloniecus y permiten adscribirlo al arte romano provincial o, en su caso, ibérico. Sin embargo, la coincidencia no es total y en ello radica la importancia del relieve, en el que el escultor puso todo su empeño en representar una deidad, pero sin recurrir a modelos preexistentes. Algunas fórmulas y motivos se toman de la iconografía romana o ibérica, tanto lejana como cercana, se combinan y, en el caso concreto de la representación del llamado Vestius Aloniecus, se dotan de nuevo contenido. De este modo surgen elementos innovadores, como el dorso de las manos que se muestra al observador con los pulgares hacia abajo. Se trata sin duda de un proceso complejo que presupone conocimientos y

83 Resumen en Bergmann, 1998.

84 Atendiendo a las dos prolongaciones podría pensarse en interpretar la figura representada como el dios Sol, pues precisamente a Sol Invictus se le representa a menudo con los brazos y las manos extendidos. Así aparece, por ejemplo, en una estatuilla del siglo II/III d. C. que se conserva en Ginebra, v. LIMC IV 1, $600 \mathrm{n}^{\circ} 116$ (Letta).

85 Cf. las ilustraciones de Nicolini, 1977 y García-Bellido, 2002/03, 227-240.

86 Maestro Zaldivar, 1989, 231 (Fig.). Muy similar también la represenación orante de una divinidad en un vaso ibérico de Puerta de San José/Cartagena, v. Belén-Escacena 2002, 165, fig. 2.

87 Fernández Uriel, 1998, 64 (Fig.). 
destrezas, lo que sorprende aún más ante la escasa calidad de la ejecución. Tal como muestra la estela funeraria del Auculus de Coria que se conserva en el Museo de Cáceres ${ }^{88}$, también en la escultura funeraria del Occidente hispano surgieron nuevas formas en las que los brazos y las manos extendidos se utilizaban como medio de expresión. En dicha escultura sujetan por detrás la cabeza en relieve (del difunto), produciendo la impresión de un abrazo. Estas imágenes no tienen parangón ni más explicación y su carácter es eminentemente local. Vestius Aloniecus es un dios local, que, de acuerdo con ambas inscripciones, solo era venerado en este lugar de Lourizán.

Dios herrero de Vilar de Perdizes (figura 4)

En un relieve de Vilar de Perdizes (Montalegre/ Portugal) que se ha presentado recientemente se representa también la figura de una divinidad masculina, aparentemente desnuda, con un martillo como atributo $^{89}$. El relieve es muy plano. La figura está de pie con los brazos colgando y el órgano sexual sobredimensionado. En la mano derecha porta un martillo; no es posible reconocer si con la izquierda sostenía otro objeto (¿tenazas?). Esta figura es la única entre las divinidades aquí estudiadas que se representa con un atributo, que contribuye a identificarle en un primer momento como el Sucellus hispano o Vulcanus; en cualquier caso, como un dios herrero ${ }^{90}$. Cicerón comentó ya la posibilidad de confundir las figuras de estas dos deidades, pues, según escribió, Vulcanus recibe un nombre diferente en cada país ${ }^{91}$. Este comentario se ve corroborado por el hecho de que, en Hispania, a Sucellus se le identifica habitualmente por otros atributos (ascia/ hacha de carpintero, maza, hacha doble) diferentes del martillo habitual ${ }^{92}$. Con todo, ni Sucellus ni Vulcanus se representan a menudo en Hispania, al contrario de lo que sucede en las provincias septentrionales del Imperio y en Italia, donde su

88 Cerrillo y Cruz 166 s., nº 5 lám. 4,1.

89 Silva, 2007, 425, nº 583, lám. 126,1. El dibujo parece no representar la escultura con fidelidad. Por ejemplo, en él se insinúa una túnica que no se menciona en la descripción. En el original tampoco se identifica como tal la eyaculación que figura en la descripción y en el dibujo.

90 V. Blázquez Martínez, 1975, 189 s., v. Vulcano.

91 Cic., De nat. deor., I, 84, v. también Brommer, 1971, 147; Blanco Freijeiro, 1975, 266.

92 LIMC VII, 1 (Zúrich und Múnich 1994) 820 s., B2 (Nagy).

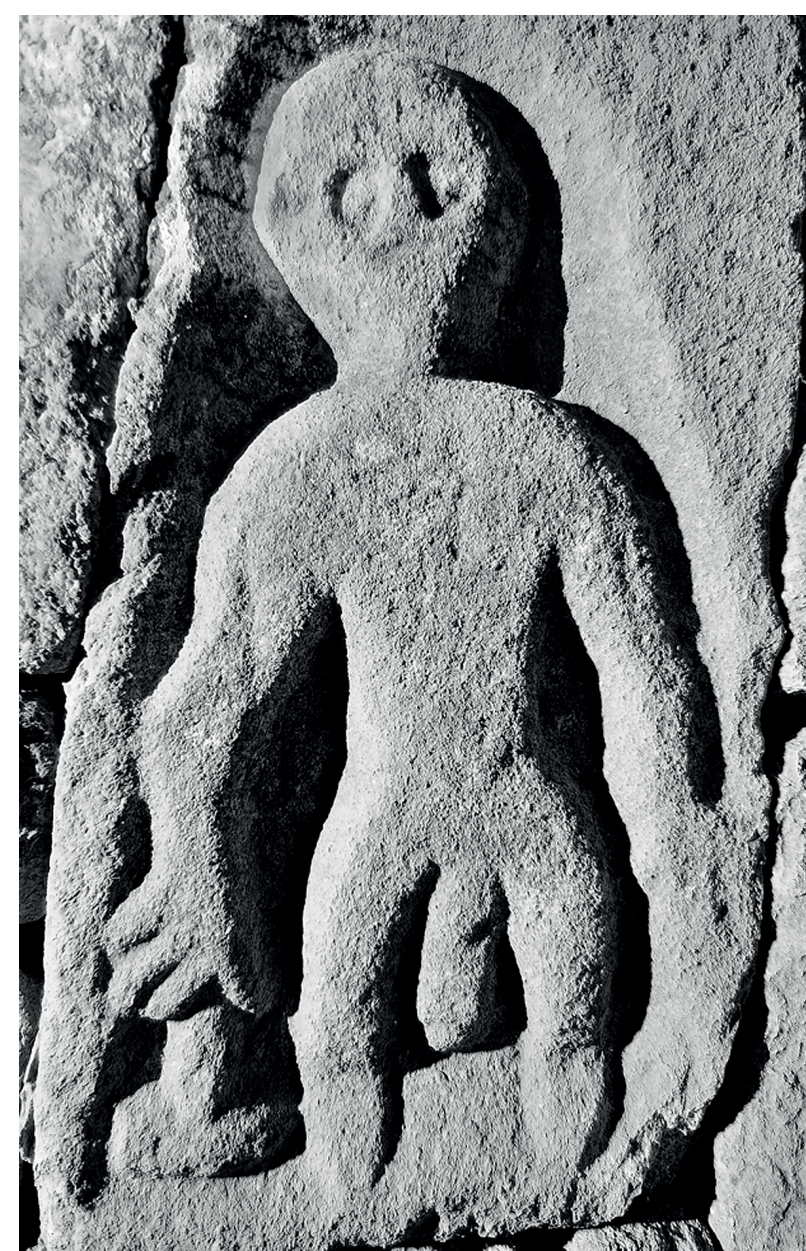

Fig. 4. Vilar de Perdizes. Dios herrero. (Fig. 4 Cedida amablemente por Armando Coelho da Silva Ferreira.

difusión es notablemente mayor ${ }^{93}$. La representación de un dios herrero en el contexto hispano en general e hispano-noroccidental en particular no resulta sorprendente ante la proverbial riqueza metalífera y el conocimiento general del arte de la herrería por parte de la población ${ }^{94}$. En el noroeste de Hispania está documentada la difusión del metal en prácticamente todos los castros ya desde la Edad

93 Vulcanus: Brommer, 1971, 147. El LIMC recoge pocos ejemplares: LIMC VIII 1 (Zúrich y Düsseldorf 1997) 287, n⿳0 34 (moneda), 290, n 73 (puteal de mármol del comercio de arte), $292 \mathrm{n}^{\circ} 93$ (moneda); v. al respecto y sobre otras piezas Brommer, 1971; Blanco, 1975. Sucellus: LIMC VII 1 (Zúrich y Múnich 1994), 820 s., nº 8.9 (estatuillas de bronce). Sobre otras piezas que se han considerado posibles imágenes v. resumen en Blázquez Martínez, 1975, 169 s., v. Sucellus.

94 Fuentes en Blázquez Martínez, 1975, 189 s., v. Vulcano. 
del Bronce, tal como ponen de manifiesto los hallazgos correspondientes (hornos) en combinación con el descubrimiento de objetos esperables en ese contexto, tales como crisoles, formas negativas o las herramientas pertinentes ${ }^{95}$. Tanto por el carácter doméstico del culto a Vulcano -muy difundido en el ámbito privado-, como por lo que nos enseñan las numerosas estatuillas de bronce procedentes sin duda de otros tantos lararia ${ }^{96}$, se habría podido esperar un número mayor de representaciones del dios.

En una lectio romana de la imagen de Vilar de Perdizes se atribuiría la desnudez heroica y el tamaño de la figura, que ocupa todo el relieve, a las representaciones de los dioses romanos ${ }^{97}$. Sin embargo, en una lectio ibérica, la comparación del tamaño exagerado del órgano sexual con estatuillas de bronce votivas, asimismo desnudas, de la cultura ibérica permitiría una interpretación en esa dirección ${ }^{98}$, pues también en el arte ibérico la desnudez tiene un sentido heroico y el órgano sexual se muestra sobredimensionado. El significado general del sexo constituye el nexo de unión. En lo que atañe al contexto, las interpretaciones indígenas pueden ser diferentes, pensándose en primer lugar en ceremonias de consagración o peticiones de fertilidad y bienestar. En cualquier caso, al destacarse el órgano sexual ${ }^{99}$, que se sitúa en el centro de la ceremonia correspondiente, se pretende despertar el interés de la divinidad. En esta lectura la desnudez se interpreta también como la clave para entender el mundo conceptual del culto, de los rituales, de las ofrendas votivas y de la divinidad ${ }^{100}$.

En el caso de Sucellus, el diccionario LIMC

95 P. ej. Vázquez Varela, 1996, 41 (“a metalurxia está omnipresente...”); resumen general en Rodríguez Colmenero, $1977,197-214$.

96 LIMC VIII 1 (Zúrich y Düsseldorf 1997), 292 (Simon).

97 Atendiendo al atributo, no cabe la remisión a la escultura de género ("Genreplastik"), en la que quizá pudiera pensarse desde un punto de vista puramente teórico, ya que la desnudez y un órgano sexual sobredimensionado también desempeñan un papel en dicho género, v. Laubscher, 1982, 59.

98 Muchos ejemplares en los catálogos especializados de Álvarez-Ossorio, 1941 (p. ej. n 204. 206-207, 214. 215, 220 , 325-329) y Nicolini, 1977 (p. ej. $54 \mathrm{n}^{0} 9,56 \mathrm{n}^{0} 10,68 \mathrm{n}^{0} 15$, $116 \mathrm{n}^{\circ} 39,220$ n. ${ }^{\circ} 86$ ).

99 Sobre una lista de la glorificación del falo en santuarios ibéricos v. Prados Torreira, 1991, 318 n 17-22.

100 Rueda Galán, 2011, 126 (con un ejemplo particularmente bueno en Fig. 55 arriba en el centro). cita 18 ejemplos, de los que tan solo tres muestran al dios desnudo ${ }^{101}$. La iconografía se remonta claramente a los modelos grecorromanos; el cuerpo se representa realizando un movimiento que se expresa, de un lado, diferenciando la pierna de apoyo de la pierna libre y, de otro lado, en el giro de la cabeza. En contraposición al relieve de Vilar de Perdizes, en el que la figura sostiene el martillo con la mano derecha, pero no lo levanta, en los otros ejemplares mencionados, los personajes sujetan el martillo con la mano izquierda y lo llevan sobre el hombro. Tan solo en algunas imágenes de Vulcano de finales de la época imperial se representa el martillo en posición baja ${ }^{102}$. En las imágenes comparables de las provincias del noroeste, Gerhard Bauchhenß ha identificado solo esporádicamente rasgos autóctonos de la divinidad, por lo demás predomina la iconografía itálica/romana general ${ }^{103}$.

Desde el punto de vista de la refinada escultura romana, la imagen estática del dios desnudo representado de frente de Vilar de Perdizes produce un efecto directo y manifiestamente interesante, hasta el punto de parecer casi original o, al menos, tan innovador y sorprendente, que la tosca y descuidada ejecución resulta refrescante. Sin duda alguna, al escultor ha de buscársele en el entorno indígena local. El cuerpo se extiende hasta ocupar prácticamente toda la superficie, omitiéndose los detalles. Es evidente que el movimiento del cuerpo tenía menos interés que la desnudez, que al igual que en las mencionadas estatuillas de bronce ibéricas constituye el elemento y el tema central. No obstante, en dichas estatuillas se representa en general a los oferentes humanos con sus ofrendas. En conjunto, el dios herrero de Vilar de Perdizes no parece una divinidad, sino más bien un demonio de la forja que se ha apropiado del rincón sagrado de la herrería. Tanto su enorme falo colgante -en lugar de erecto, como aparece a menudo en el arte ibérico- como su desnudez evocan más bien la imagen de una persona de clase baja que la de un dios poderoso. Dos detalles poco claros para terminar: la figura parece estar circuncidada y en la mano derecha parece que le falta un dedo.

A modo de resultado intermedio cabe decir que

101 LIMC VII (Zúrich y Múnich 1994), 820 s., nº 1. 2. 17 (Nágy).

102 LIMC VIII 1 (Zúrich y Düsseldorf 1997), $284 \mathrm{n}^{\circ} 4-7$ (monedas); $294 \mathrm{n}^{\mathrm{Q}} 102$ (piedra de los cuatro dioses).

103 LIMC VIII 1 (Zúrich y Düsseldorf 1997), 293 (Bauchhenß). 
en los componentes de las imágenes de Lourizán y Vilar de Perdizes se identifican ambivalencias que no es fácil atribuir a una tradición iconográfica ya sea romana, ibérica o indígena. Si bien la ejecución parece un tanto tosca en ambos casos, las imágenes reflejan iniciativas propias de los escultores del noroeste hispano que les confieren un carácter original, motívico y artísticamente convincente. Con relación al tema del que estamos tratando, la situación es la siguiente: la representación de imágenes de divinidades propias se lleva a cabo con los medios autóctonos ("galaicos") disponibles, recurriendo eventualmente a los elementos del arte romano e ibérico que podían servir de modelo para determinados componentes iconográficos.

\section{Deus Endovellicus (figura 5 y 6)}

Una solución totalmente distinta es la que presenta la cabeza masculina de mármol descubierta en el santuario del dios Endovélico en São Miguel da Mota/Alandroal (Portugal) ${ }^{104}$. Sin duda, se trata de un retrato ideal. La cabeza es de tamaño natural. Una densa cabellera enmarca el rostro liso, está estructurada en mechones que forman una variedad de dibujos en torno al cráneo y terminan en bucles. En la frente llama la atención el característico flequillo que se conoce de la iconografía de Octaviano, lo que ha llevado a datar la imagen en el siglo I d. C., datación que nadie ha refutado hasta ahora ${ }^{105}$. Sin embargo, el estudio de los rizos de la barba, curvados al estilo arcaico (figura 5b. 6a), su disposición y su forma apuntan a una fecha posterior, que no encontraría un paralelismo hasta bien entrado el siglo II d. C. En este contexto cabe remitirir ${ }^{106}$ a un retrato

104 En la generación actual ha vuelto a suscitarse precisamente el debate sobre la cabeza (bibliografía reciente LIMC III 1 (Zúrich/Múnich 1986), 726 n 1; CSIR Portugal, 1990, 33 nº 78; Blech, 1993 b, 396 s,. lám. 197; De Matos, 1995, 134 s., nº 61; Koppel, 1999, 308; Ribeiro, 2002 b, 381 $\mathrm{n}^{\circ}$ 31; Ribeiro, 2005; Gonçalves, 2007, 307 s. n 131; Schattner, Guerra y Fabião, 2009; Gonçalves, 2013, 24 n 131; Fabião, Guerra y Schattner 2013, 86-95), tanto la exposición final como la fundamentación de la datación se realizan en el marco de la publicación del santuario de Endovélico (Guerra, Fabião y Schattner, en prensa), por lo que ante la inminente publicación no es necesario explayarse aquí más de lo necesario.

105 Recopilación de las dataciones realizadas hasta la fecha en Gonçalves, 2007, 308.

106 Fabião, Guerra y Schattner, 2013a, 88. Mi agradecimiento a Stefan Lehmann/Halle y Dieter Salzmann/Münster por su disponibilidad para el debate y sugerencias.
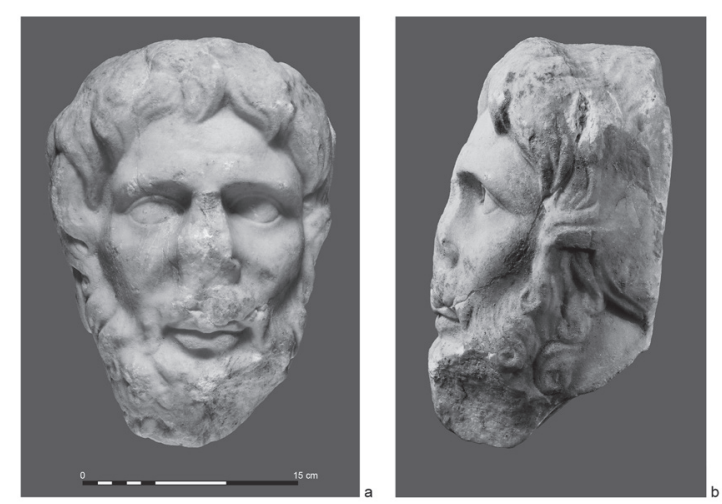

Fig. 5. São Miguel da Mota. Cabeza de Endovélico, a frente, b lado. (Fig. 5D-DAI-MAD-MLA-DG-024-2016-029)
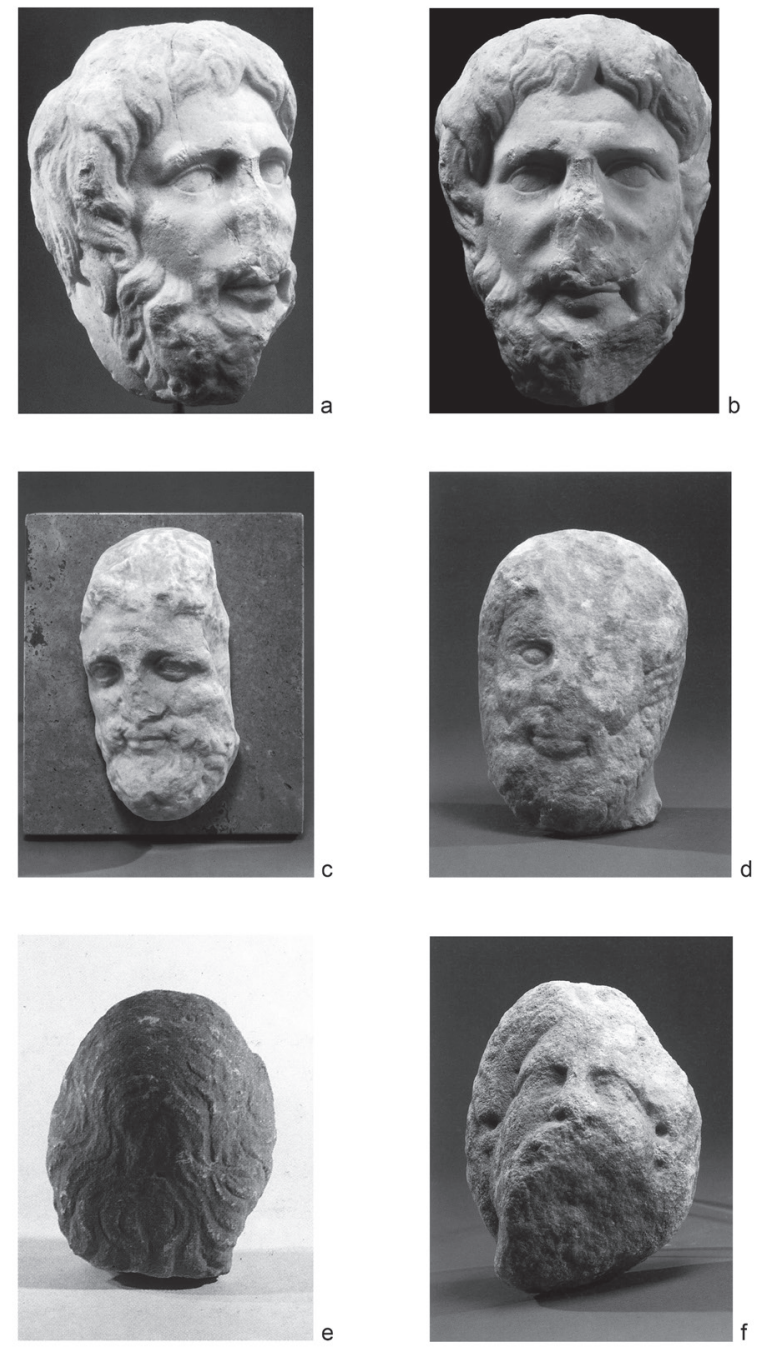

Fig. 6. São Miguel da Mota. Cabezas votivas de Endovélico. (Fig. 6 Cabeza de Endovélico, alado, b frente, c-f cabezas votivas) 
hallado en Tesalónica ${ }^{107}$, que muestra a un "ciudadano ataviado con toga de filósofo", perteneciente a la época antonina ${ }^{108}$. Vista de frente, la cabeza de Endovélico presenta una forma más antigua que vista de perfil. Es posible que, al realizar la vista de frente, para reproducir el flequillo y la distribución de los bucles sobre la frente, el escultor se inspirara en modelos antiguos, mientras que para representar la barba, que destaca sobre todo en la vista de perfil, recurriera a modelos coetáneos. Asimismo es evidente que para realizar el retrato no se basó en ninguna divinidad paternal ("Vatergottheiten")109, sino en retratos de poetas, filósofos o héroes ${ }^{110} \mathrm{o}$ en su caso en imágenes similares de ciudadanos distinguidos, que Paul Zanker ha denominado "bustos cultos”, a los que pertenece el busto de Tesalónica citado más arriba como paralelismo ${ }^{111}$. Zanker se refiere a bustos de ciudadanos que, al asimilarlos a los retratos de los filósofos, ponen de manifiesto su intelectualidad y afinidad con la cultura griega, un fenómeno que fue ganando adeptos desde Adriano y la implantación de la barba como resultado de la nueva orientación cultural -es decir, filohelénicadel programa de gobierno de este emperador ${ }^{112}$. Los "bustos cultos" como los mencionados abundaban en el Imperio romano ${ }^{113}$. Teniendo en cuenta que en Augusta Emerita, la capital del Occidente hispano, había talleres que trabajaban también para la dinastía imperial ${ }^{114}$, puede presumirse que desde los primeros tiempos de la época imperial se disponía in situ de los conocimientos técnicos y conceptuales necesarios para realizar tales bustos, a pesar de que hasta ahora no se conoce ninguno procedente de Augusta Emerita ${ }^{115}$.

Al faltar imágenes más antiguas de Endovélico, el citado retrato ideal puede considerarse sin duda una creación nueva. El fenómeno de este empeño innovador no es desconocido. Desde la época helenística, los escultores se tuvieron que enfrentar con frecuencia al reto de realizar retratos retrospectivos de poetas y filósofos del pasado sin tener posibili-

107 Bakalakis, 1973, 682, Fig. 9.

108 Zanker, 199, 217, Fig. 123.

109 Recopilación de las esculturas en Thiemann, 1959.

110 Schattner, Guerra y Fabião, 2009.

111 Zanker, 1995, 216.

112 Zanker, 1995, 190-251.

113 Zanker, 1995, 216.

114 V. arriba nota 4.

115 Recopilación de los retratos de la capital lusitana: Nogales Basarrate, 1997. dad de recurrir a modelos iconográficos. A título de ejemplo cabe citar los retratos del poeta épico Paniasis, del poeta Hiponacte (?), del médico Hipócrates y del filósofo Anaximandro ${ }^{116}$. Del santuario de Endovélico proceden también otras cabezas masculinas con barba que desde el punto de vista formal pueden incluirse en el mismo grupo. Una es asimismo de tamaño natural, la otra, bastante más pequeña (figura $6 \mathrm{c}-\mathrm{f}$ ). Son muy similares a la cabeza que aquí presentamos, las características principales, como la presentación facial, la disposición del cabello y los rasgos fisionómicos generales coinciden plenamente, al igual que otros detalles más llamativos, como los ojos juntos y profundos y la boca cerrada. Las cabezas poseen un aire de familia que las une, las diferencias afectan solamente a la calidad de la ejecución. La calidad de las cabezas citadas en último lugar (figura 6 c-f) es claramente inferior a la del ejemplar conocido y descrito al comienzo de este capítulo (figura 5 a. b. 6 a.b.), por lo que su datación resulta difícil. Las dataciones realizadas en el pasado, que las sitúan en el siglo I d. C., se han hecho siempre sobre la base de la cabeza de mayor calidad y datable con seguridad (figura 5. 6 a. b) ${ }^{117}$. Metodológicamente, esta vía parece correcta.

En cuanto a la interpretación de la cabeza, todos los autores han seguido a José Leite de Vasconcellos, quien ya en 1905 vió en ella la representación de un dios ${ }^{118}$. Al margen de ello, Scarlat Lambrino aportó un argumento interesante en relación con su interpretación y su datación: como en el siglo I d. C. la barba y una cabellera tan abundante no eran habituales entre los romanos, la imagen no puede corresponder a un ser mortal, sino a una divinidad, y dado el lugar del hallazgo en el santuario de Endovélico, no puede tratarse de ningún otro dios, salvo Endovélico ${ }^{119}$. Se trata sin duda de una petitio principii bastante obvia: si el rostro presenta rasgos ideales y la pieza fue hallada en el santuario, solo puede ser la representación de una deidad. Como, además, en ese santuario solo se honraba a Endovélico, este dios es el único que puede tomarse en consideración. Sin embargo, ise trata realmente de la cabeza perteneciente a la estatua a la que se rendía culto?

Según los datos que se conocen hasta ahora, el santuario de Endovélico se construyó en la época

116 Zanker, 1995, 150-154, Fig. 81-84.

117 García y Bellido, 1949, 126 n² 127. 128; CSIR Portugal, 1990, 33 (julio-claudia).

118 Vasconcellos, 1905, 140, Fig. 26.

119 Lambrino, 1951, 107. 
julio-claudia ${ }^{120}$. En esta fase temprana ya había edificios y cierta decoración escultórica, como demuestran los restos arquitectónicos correspondientes y los fragmentos de los togados ${ }^{121}$. El hallazgo de la estatua de una cariátide, que, como la cabeza descrita (figura 5.6 a), parece remontarse a la época adrianea/ antonina, apunta a la existencia de (¿otro?) edificio $(\text { ¿templo? })^{122}$. Si la datación de la cabeza es correcta, el contexto de la ubicación plantea varios problemas, a la vez que se abren varias soluciones posibles puramente teóricas, que, al faltar argumentos pertinentes, solo pueden tener carácter especulativo ${ }^{123}$ :

Hipótesis: junto con la creación del santuario en época julio-claudia se construyó un templo que albergaba una imagen de culto.

Comentario: en la zona excavada se ha encontrado un edificio de esta época que, eventualmente, podría interpretarse como templo. Sin embargo, falta cualquier rastro de la imagen primitiva a la que se rendía culto. En esta constelación, las cabezas descritas del siglo II d. C. (figuras 5 y 6), que evidentemente representan al dios de una $u$ otra forma, deberían considerarse ofrendas votivas.

Hipótesis: el templo mencionado fue reformado en época adriana o quizá se construyó un templo nuevo en el que se colocó tanto la cariátide-incluida la pareja que falta- como la cabeza aquí descrita (figura 5.6 a. b), que podría pertenecer a la imagen de culto correspondiente.

Comentario: es posible que el templo nuevo se encontrara debajo de la capilla que Vasconcellos desmanteló en las campañas de 1890, 1904 y $1907^{124}$. Por su tamaño y excelente factura, la cabeza aquí descrita podría interpretarse como una imagen de culto, pero también podría haber pertenecido a una estatua votiva, más aún cuando entre los hallazgos figura otra cabeza de tamaño similar aunque de inferior calidad (figura 6e). El tamaño por sí solo no puede considerarse por ello la característica esencial de la estatua de culto.

Hipótesis: ante la escasa fuerza persuasiva de los argumentos a favor de la construcción de un nuevo templo en época adrianea (ver hipótesis nú2013.

120 Guerra et al., 2005, 198; Fabião, Guerra y Schattner,

121 Guerra, Fabião y Schattner, en prensa.

122 Schattner, Guerra y Fabião, 2008, 720.

123 Los hallazgos arqueológicos que se comentan a continuación se mencionan anticipando la publicación de Fabião, Guerra y Schattner, prensa.

124 Recientemente Fabião, Guerra y Schattner 2013. mero 2) puede pensarse en que la cariátide no formaba parte del conjunto arquitectónico, sino que era una escultura independiente según el modelo de las cariátides existentes en la villa de Adriano en Tívoli. En este caso, la cabeza aquí descrita (figura 5.6 a. b) podría interpretarse como una estatua votiva o como sustitución de la imagen de culto más antigua, según la hipótesis planteada en la hipótesis 1.

Comentario: la similitud entre la cariátide del santuario de Endovélico, en cuanto a tamaño y forma, y los ejemplares del llamado foro de mármol de Augusta Emerita ${ }^{125}$, permite suponer un uso arquitectónico también en el santuario. La hipótesis de una estatua independiente sería la lectio dificilior.

A modo de resumen cabe decir, por tanto, que al realizar la estatua de Endovélico, que atendiendo a su nombre es una divinidad indígena, el escultor se inspiró en el arte romano, del que tomó no sólo el nivel de calidad que en general distingue las obras de arte romanas, sino también la afición a los detalles y la precisión de la representación. El escultor se había formado en el arte romano y supo sacar provecho de las posibilidades que dicho arte le brindaba para crear la imagen de una divinidad con nombre autóctono totalmente al estilo de un dios romano. Conocía perfectamente el repertorio romano y lo dominaba con especial maestría. El resultado de su buen hacer es la imagen de una divinidad que no se diferencia en nada de un equivalente de Roma.

\section{Dis Pater en Munigua (figuras 7 a 11)}

El santuario de Dis Pater se encuentra en el ala norte del foro del municipio hispano-romano de Munigua (figura 7a), encajado entre el tabularium al este y la curia al oeste (figura 7b). Con una superficie de algo más de $10 \mathrm{~m} 2$ pertenece al grupo de espacios pequeños del foro ${ }^{126}$. En 1976, Wilhelm Grünhagen lo identificó con razón como la capilla de Dis Pater y describió y presentó el monumento que había en ella ${ }^{127}$. De acuerdo con su descripción, se trata de un zócalo de granito

125 Reciente estudio detallado en Ayerbe Vélez et al., 2009; Goldbeck, 2015, 68-79.

126 De tamaño inferior es tan solo la dependencia aneja a la curia (Hauschild, 1986, 329 Fig. 3 n. ${ }^{\circ}$ 5); sobre su descripción v. ahora Schattner, 2013b.

127 Grünhagen, 1976. 
de $1,73 \mathrm{~m}$ de altura, compuesto por varias piezas, sobre el que originariamente se encontraba la estatua de un caballo de tamaño natural (figura 8). La estatua ha desaparecido, como era de esperar, pero la forma de los huecos que se han conservado en la placa base para la inserción de las patas de un cuadrúpedo son característicos de las estatuas de bronce, lo que permite determinar el material de la misma. La altura total del monumento debía rondar los tres metros y medio y, en consecuencia, para el recinto en sí cabe suponer una altura de 4 metros, como mínimo ${ }^{128}$. Estos datos indicarían la existencia de un habitáculo de planta más bien pequeña, pero de una altura descomunal (figura 9).

La inscripción permite deducir que se trataba de la estatua de un equino (figura 10). F. Collantes de Terán y C. Fernández-Chicarro fueron los primeros en publicar la inscripción de la estatua, que a continuación fue analizada detenidamente e interpretada por Grünhagen ${ }^{129}$. La publicación cita al principio el nombre de la divinidad, el numen Dis Pater, y a continuación sigue el nombre del donante, Lucius Aelius Fronto, de la tribu Quirina. Fronto es conocido en Munigua como donante de una estatua para Vespasiano ${ }^{130}$ y con toda seguridad pertenecía a la primera generación de honoratiores que asumieron los cargos más importantes en el municipio recientemente creado ${ }^{131}$. En las dos últimas líneas Grünhagen lee EQUUM AEDEM EQUILEM DEDIT. Según este autor, la inscripción dice que $L u$ cius Aelius Fronto, miembro de la tribu Quirina, dedicó al dios Dis Pater un caballo y, a modo de cuadra, un templo donde alojarlo ${ }^{132}$. En esta lectura, el término equilem se entiende como adjetivo derivado de equilis y hace referencia al sustantivo aedem. En este contexto hay que hacer la salvedad de que el adjetivo en sí no ha sido transmitido, sino tan solo el sustantivo equile, que significa cuadra

128 Las medidas resultan del cálculo siguiente: $1,73 \mathrm{~m}$ altura del zócalo más el tamaño del caballo más la distancia respecto del techo del habitáculo.

129 Collantes de Terán y Fernández-Chicarro 1972-74, 349-351 H1; todos los datos siguientes según Grünhagen 1976, 229-235. Grünhagen,

130 CILA SE, 1064; Gimeno, 2003, 179.

131 Gimeno Pascual, 2003, 179; sobre el reconocimiento del fuero municipal en general v. Caballos Rufino, 2001; a Munigua, v. Schattner, 2013b, 348-350.

132 La mención de una cuadra nos lleva a pensar en Juvenal, Sat.8,156-7, y sus burlas sobre los altares dedicados a Epona en establos malolientes. o caballeriza. No obstante, también es posible una lectura sustantivada, en la que los sustantivos aedem y equilem se yuxtaponen de forma paratáctica y aditiva. Si se toma esta lectura como punto de partida, la conclusión sería que Aelius Fronto donó dos edificios, un templo y una cuadra para el caballo.

Por otro lado, el término equus es, en general, sinónimo de statua equestre (estatua ecuestre). De este modo, el equus Domitiani o el equus Traiani del Foro de Trajano eran estatuas ecuestres de los respectivos emperadores al estilo de la estatua ecuestre de Marco Aurelio. En la estatua de Munigua hay que descartar, sin embargo, una interpretación en dicho sentido. De una parte, porque falta el nombre del jinete en cuanto personaje central y, de otra, porque para erigir un monumento de esa índole se habría necesitado el acuerdo correspondiente del Senado de Munigua, expresado mediante la fórmula ex decreto ordinis, que falta también, $y$, por último, porque un monumento de semejantes características habría estado dedicado en su totalidad a Dis Pater. Desde un punto de vista puramente teórico, podría pensarse en la construcción de un monumento para recordar a un caballo concreto, al estilo del que Adriano mandó erigir en memoria de su querido Borístenes en la localidad gala de Apte. También en este supuesto surgen dificultades epigráficas, puesto que la inscripción no incluye ninguna referencia a dicha posibilidad, sino, por el contrario, a la donación de una aedes, tal como hemos visto. Basándose tanto en la mención del nombre del donante, Aelius Fronto, como en argumentos estratigráficos, Grünhagen dató el monumento en la época posterior al año $79 \mathrm{~d}$. C. como terminus post quem, es decir, en la época flavia de los años 80 del siglo I d. C.

A raíz de la interpretación de Grünhagen, los epigrafistas han estudiado detenidamente la inscripción en repetidas ocasiones ${ }^{133}$. La lectura de exedram en lugar de aedem ha llevado asimismo a J. González a una interpretación sustantivada y a presuponer tres donaciones: la estatua del caballo, una exedra y una cuadra o establo. Mientras que la investigación está de acuerdo con la identificación del caballo y la cuadra y su conexión con la estatua y el espacio correspondiente en el foro (figura $7 \mathrm{a}$ ), no ocurre lo mismo con la exedra. La investigación filológica y arqueoló-

133 AE, 1972, 255; AE, 1975, 501; AE, 1980, 561; CILA SE,1056; Gimeno Pascual, 2003, 179. 

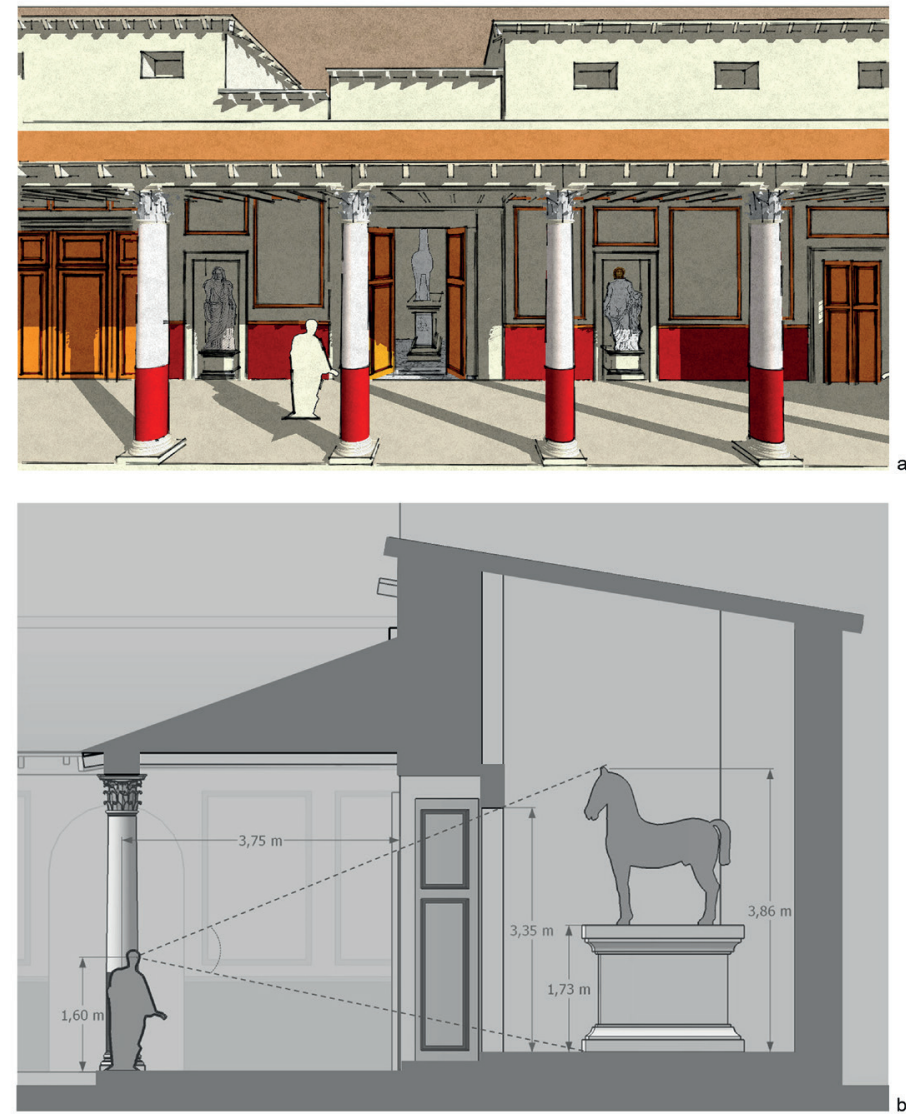

Fig. 9. Munigua, foro. Reconstrucción del pórtico norte, a el santuario de Dis Pater en el centro flanqueado por las estatuas del genius municipii y del Bonus Eventus, b sección reconstruida (Fig. 9 a. b. DAI Madrid, Archivo de Munigua, reconstrucción H. Ruipérez)
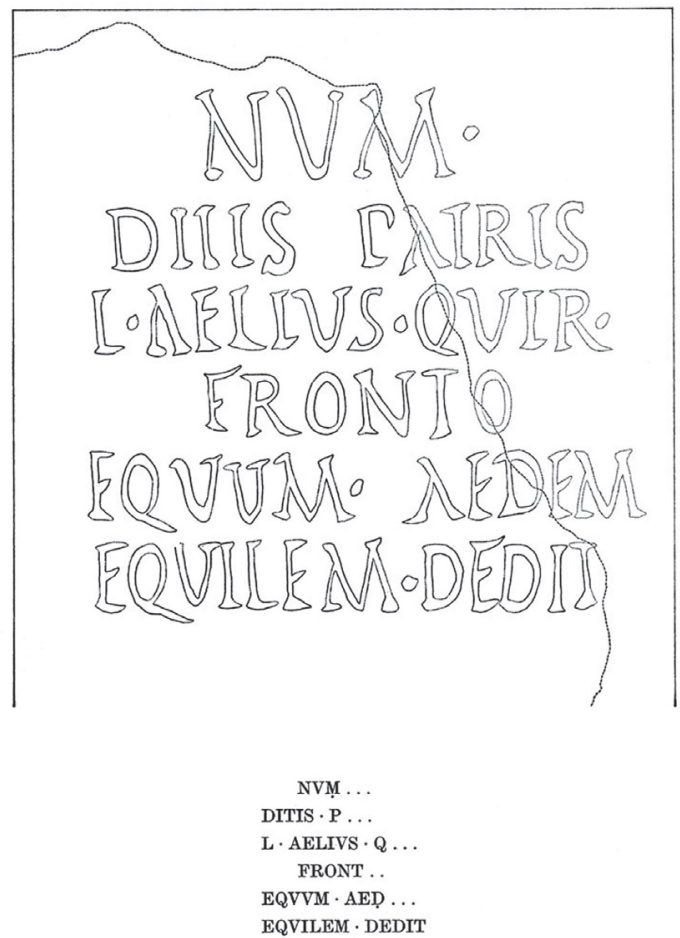

Fig. 10. Munigua. Inscripción de Dis Pater, transcripción. (Fig. 10 Según Grünhagen 1976, 230 Fig. 3)

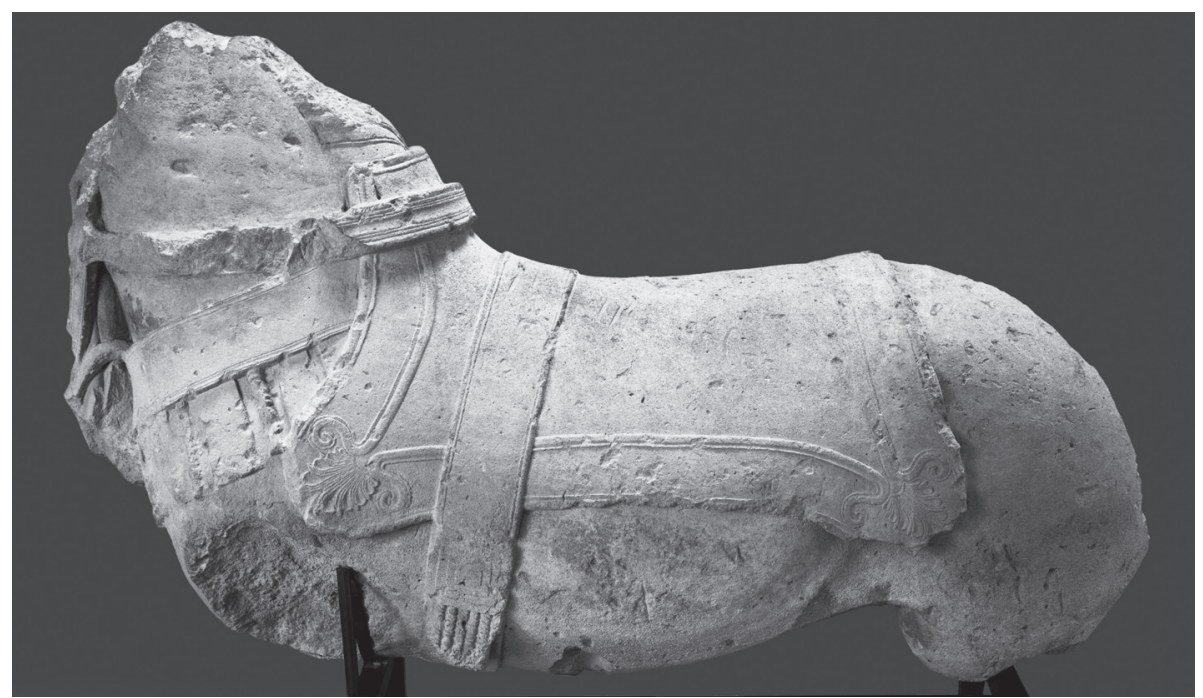

Fig. 11. Casas de Juan Núñez (Jaén), estatua de caballo ibérica. (Fig. 11 DAI Madrid, Archivo de Munigua, D-DAI-MAD-WIT-R-8-79-10) 
gica ha destacado el uso lingüístico y arquitectónico del término, que ya estaba muy extendido en la Antigüedad con valor polisémico. A modo de resumen solo cabe constatar que este término se utilizaba tanto para designar una construcción independiente, abierta, con paredes, de cualquier tamaño, incluso monumental, como para referirse a las estatuas que se colocaban en su interior o encima de un pedestal. Este uso es sin duda una reminiscencia de su significado original, es decir, «asiento», si bien las exedras eran generalmente de planta más o menos semicircular dividida en segmentos ${ }^{134}$. Si la lectura de González fuera acertada y en Munigua se mencionara de hecho una exedra, personalmente propondría identificar el término con el zócalo del tamaño de una persona que servía de base a la estatua, pues, excepto la planta semicircular, reúne todas las características citadas. En mi opinión, no hay ninguna otra explicación posible. El foro ha sido excavado en su totalidad; la investigación ha concluido y los resultados se publicarán próximamente ${ }^{135}$. En este lugar no existe ninguna exedra en el sentido habitual del término ${ }^{136}$ y tampoco se sabría dónde buscarla; la función de los espacios del foro se conoce perfectamente y el templo, que quizá podría relacionarse con aedes, ha sido reivindicado recientemente -con sólidas razones- como la morada de Ceres, documentada epigráficamente en Munigua ${ }^{137}$. El problema se complica si se piensa que la exedra en cuestión debería buscarse en las inmediaciones del santuario de Dis Pater, ya que su donación se menciona en una inscripción.

Una reciente e innovadora interpretación de la inscripción por A. Canto, según la cual la estatua habría sido de plomo y la cuadra, de mármol ${ }^{138}$, no ha encontrado eco en la investigación, al menos hasta ahora.

Resumiendo, el monumento está dedicado al caballo y es en él en quien debemos fijarnos. En la reconstrucción se presenta desensillado y sin jine-

134 Settis, 1973, 666-671; Thüngen, 1994, 3-5.

135 Schattner, en prensa 2.

$136 \mathrm{Al}$ noroeste del foro, en la cuña entre la calle del foro y la calle de la ladera existen unos cimientos sin excavar formados por grandes bloques de granito que parecen ser de forma semi (?) circular y en ese sentido podrían interpretarse como exedra (Schattner, en prensa 2). No obstante, se encuentran lejos del foro y, por ello, no guardan ninguna relación con el santuario de Dis Pater propiamente dicho.

137 Uso y función de los espacios del foro: Hauschild, 1986; Schattner, 2013b; Ceres como diosa del templo del foro: Schattner, 2018.

$138 \operatorname{HEp}$ 7, 1997, 915 (Canto).
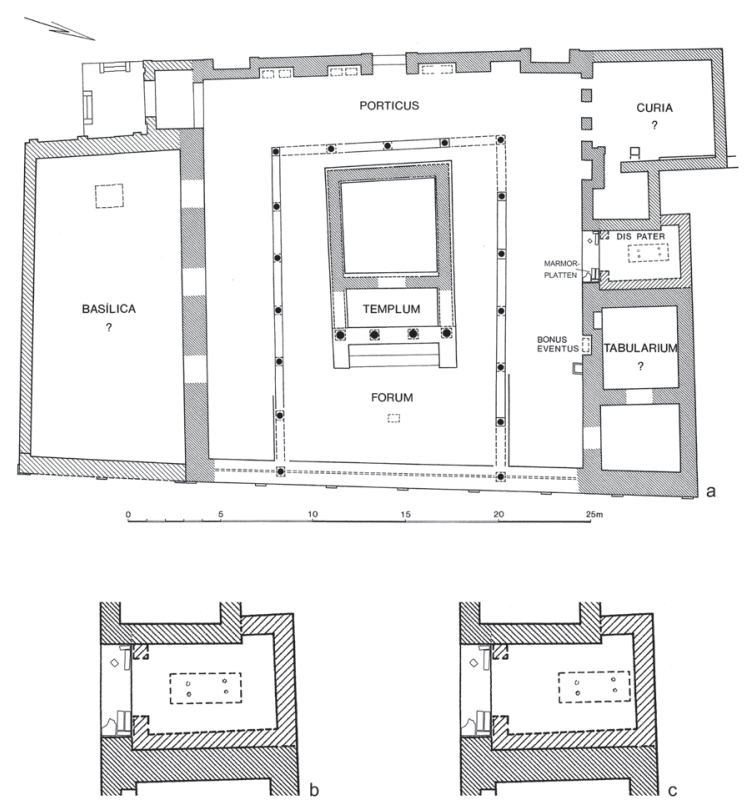

Fig. 7. Munigua, foro. Fase flavia, a plano general, b recinto del santuario de Dis Pater, zócalo de la estatua en el centro, c recinto del santuario de Dis Pater, zócalo de la estatua desplazado a la pared posterior. (Fig. 7 a. b según Hauschild, 1986, 332 Fig. 5; c DAI Madrid (E. Puch Ramírez) sobre la base de Hauschild, 1986, 332 Fig. 5)
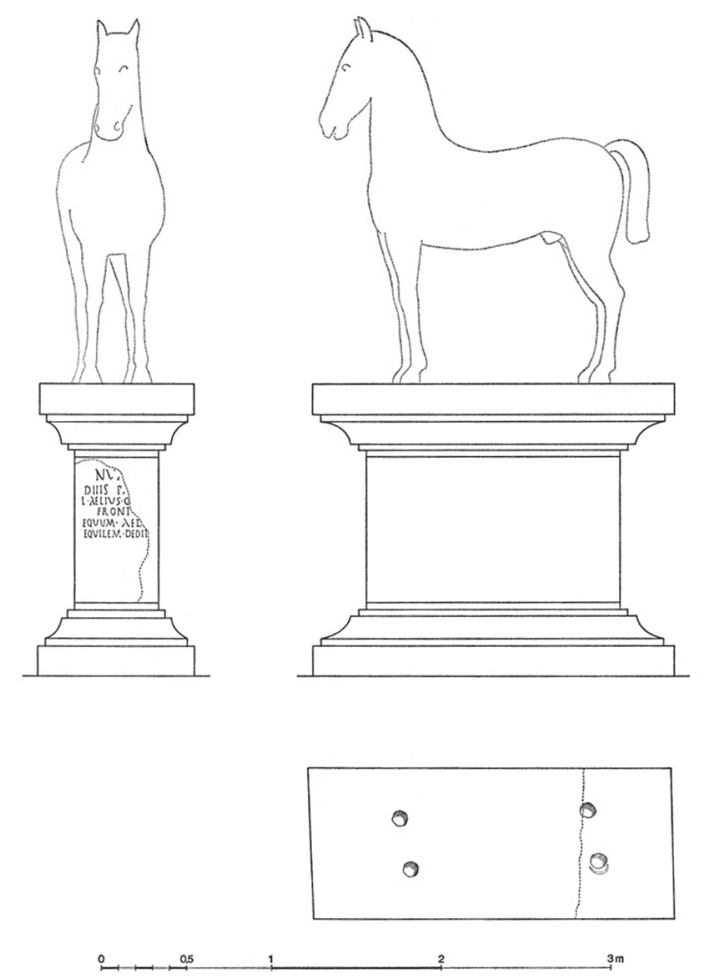

Fig. 8. Munigua, foro. Estatua y zócalo de Dis Pater. (Fig. 8 Según Grünhagen, 1976, 228 Fig. 2) 
te. En este punto conviene recordar que en el arte romano solo se conocen caballos montados o guiados $^{139}$, pero no caballos sin jinete ${ }^{140}$. Sin embargo, estas esculturas sí aparecen en el arte del este y del noroeste (cultura de los castros) de Hispania, así como en el arte celta de la Galia y de Germania.

En varios santuarios de Iberia se han encontrado numerosos ejemplos ${ }^{141}$; del complejo ibérico de El Cigarralejo (Murcia) se han publicado más de 200 estatuas de caballos, algunos ensillados y otros sin jinete ${ }^{142}$, sobre todo en relieves votivos de pequeño formato, que por su tamaño pueden omitirse en el presente estudio. En cuanto a las esculturas grandes, que en el arte ibérico nunca alcanzan el tamaño de una persona, el ejemplo más conocido es el caballo ensillado de Casas de Juan Núñez (Jaén), con longitud de $1.116 \mathrm{~cm}$ y altura de $75 \mathrm{~cm}$ ), esculpido en piedra caliza (figura 11) $)^{143}$.

139 Sobre todo por los Dioscuros, v., p. ej., en el templo de los Dioscuros en Cori (Altenhöfer, 2007, 394, Fig. 18) y en gemas (Vollenweider, 1972-74, 43 s., $\mathrm{n}^{\mathrm{0}} 68,1 ; 44$ n. ${ }^{\circ}$ 69,4), pero también en lápidas, v., p. ej., B. Espérandieu, 1931/1965, 27 s., n 32; Gabelmann, 1972, 128, Fig. 40 (de Klagenfurt); CSIR Deutschland III 1, 40 s., $n^{\circ}$ 22, lám. 24 (de Xanten), 44-46, nº 29, lám. 30 (de Kalkar); Selzer 1988, 39, Fig. 22; 55, Fig. 37 (Dioscuros); 57, Fig. 41; CSIR Alemania II 11, 71 s., n ${ }^{\mathrm{e}} 13$, lám. 8 (de Wiesbaden).

140 Los caballos sin jinete aparecen en representaciones de áreas cronológica o geográficamente marginales. Por ejemplo, en monedas de la Campania romana de principios del siglo III a. C. (Kent, Overbeck y Stylow, 1973, 13, lám., $5 \mathrm{n}^{\mathrm{Q}}$ 10; Coarelli, 2011, $194 \mathrm{n}^{\mathrm{Q}} 2$ 2, Fig. 185), o en monedas de las ciudades de Termessous (RPC 1992, $\mathrm{n}^{\circ}$ 3358. 3360), Antioquía ad Hippium (RPC 1992, n. ${ }^{\circ} 4808$ ) o Tesalia. Su importancia se deriva del contexto local correspondiente, pero su influencia no se extendió más allá. Las imágenes de los mosaicos de Villa Fortunatus, que es una villa rústica romana situada en la localidad de Fraga (Tarradell, 1969, 165 Fig. 144. 145), pertenecen al contexto hispano mencionado con anterioridad.

141 Cuadrado Díaz, 1950, 126-, lám. 9-18; Rodríguez Oliva, 1983 (de Cerro de los Infantes, Pinos Puente (Granada), la antigua Ilurco); Fernández Gómez, 2003 (de Mesa de Luque). Algunos se interpretan también como relieves funerarios, p, ej., un ejemplar de Martos (Jaén) (Recio Veganzones, 1994).

142 Cuadrado Díaz, 1950, 67-142 lám. 26-68; otras imágenes, p. ej. en: García y Bellido, 1971, 52 s., lám. 90-94; Beltrán Lloris, 1996, 179 (fotografía en color); Die Iberer, 1998, 327, n 230. 358, n 343; Escacena, 2002, 61 lám. 6, Fig. 9. Como observan Quesada Sanz y Gabaldón Martínez, 2008, 147, nota 9, en este santuario, las estatuas dedicadas a caballos sobrepasan ampliamente las antropomorfas.

143 Chapa Brunet, 1986, 63 y 159 s.; Die Iberer, 1998, 179 y 263, n. ${ }^{\circ} 37$; Blech, 2001a, 621, lám. 219 a y b (con
Monumentos similares se conocen también en la parte indoeuropea de Hispania, es decir, en el noroeste ${ }^{144}$. Entre las citadas esculturas de la construcción de Monte Mozinho figuran asimismo restos fragmentarios que apuntan a la existencia de un caballo de granito ${ }^{145}$. Tal como afirma Teresa Soeiro ${ }^{146}$, estos restos se descubrieron en un estrato tardoantiguo, estableciendo así un terminus ante quem. En concreto, se trata de varios fragmentos grandes de la estatua de un caballo de tamaño ligeramente inferior al natural, entre ellos, la cabeza y un casco delantero, así como del zócalo correspondiente, en el que se ha conservado el arranque de las patas traseras. En un fragmento del cuello se aprecian huellas de óxido, lo que indica que las riendas tuvieron que ser de hierro. A su vez, en la cabeza se ha conservado una espiga vertical de hierro, que, en opinión de Teresa Soerio, servía para anclar la estatua en un marco arquitectónico, por ejemplo, un entablamento superior.

Si esta teoría es correcta, es evidente que el caballo no tenía jinete. Ciertamente, es posible que la espiga desempeñara otra función, por ejemplo, servir de sujeción a las crines o a la melena (iesculpidas por separado?), elementos bastante habituales en las estatuas de caballos ${ }^{147}$. Del hallazgo en sí no cabe sacar más conclusiones ${ }^{148}$. En mi opinión, la posibilidad de que el caballo estuviera montado por un jinete puede descartarse sin más por el simple hecho de que se utilizó granito y este material es realmente inusitado en este tipo de esculturas. Las estatuas ecuestres conocidas, de las que de un modo u otro han llegado hasta nosotros más de 100 procedentes del Imperio romano, son en su mayoría de bronce y algunas de mármol ${ }^{149}$. La reconstrucción como estatua ecuestre que puede verse en el Museo

bibliografía más antigua). Naturalmente, la escultura ibérica conoce también los caballos montados y la figura del jinete; en la escultura en pequeño formato v., p. ej., Cuadrado Díaz, 1950, lám. 9 y 10; García y Bellido, 1971, Fig. 115 y 118; en la escultura en formato grande v., p.ej., Die Iberer, 1998, 133 y 308, nº 181., 355, nº 336; Blech, 2001b, lám. 226 a; Blech, 2001c, 628, lám. 227.

144 Sobre la división de la península ibérica en las distintas zona, v. ahora Schattner, 2015.

145 V. supra cap. II Imágenes de divinidades, el llamado Vestius Aloniecus de Lourizán.

146 Soeiro, 1984, 266.

147 Cf. láminas en Bergemann, 1990.

148 Las fotografías publicadas en las citadas publicaciones de Almeida, 1974 y Soeiro, 1986, son de mala calidad y no permiten un estudio ni una evaluación pormenorizados.

149 Bergemann, 1990, 2 s y 21 s. 
de Penafiel no es verosímil; en ella se ha utilizado una de las cabezas citadas ${ }^{150}$, esculpida muy toscamente en un bloque de granito en el que se han practicado dos agujeros a modo de ojos y una estrecha abertura a modo de boca. Esta cabeza en modo alguno puede considerarse un retrato romano; para completar una auténtica estatua ecuestre, como las que se conocen habitualmente, se requiere un retrato auténtico, pues estas estatuas representan sin excepción a miembros de la clase alta ${ }^{151}$. Nunca se habría elegido el granito como material para realizar un retrato, sino mármol o, como mucho, una piedra caliza de calidad. Debido al grosor de los granos, el granito no es adecuado para reproducir los detalles fisonómicos en una escultura refinada. A lo anterior se suma el argumento relativo al emplazamiento. Por regla general, las estatuas ecuestres romanas se situaban en la ciudad y, en concreto, en un "celeberrimus locus", como el foro o el teatro, pero nunca extramuros a lo largo en las vías sepulcrales ${ }^{152}$. Según la reconstrucción del Museo Municipal de Penafiel, deberíamos imaginarnos una estatua ecuestre esculpida en granito -caballo y jinete- situada fuera de los límites del castro de Monte Mozinho. La posibilidad de un cambio de material, de forma que el caballo fuera de granito y el jinete de mármol, de piedra caliza o incluso de bronce, resulta igualmente inverosímil. Tanto las diferentes peculiaridades enumeradas serían tan extraordinarias como su combinación en un emplazamiento extramuros. Como una reconstrucción con jinete de tal índole tendría que operar necesariamente con numerosas incógnitas, como el cambio de material entre caballo y jinete, la inexistencia de un retrato, la ausencia de una inscripción honorífica y el emplazamiento fuera de la ciudad, surge la interpretatio dificilior. Prescindiendo de tantas especulaciones, la interpretatio facilior es aceptar la existencia de una estatua de granito que representaba un caballo sin jinete de tamaño natural.

Las esculturas de caballos solos son también conocidas en el arte celta y céltico-romano de la

150 La reconstrucción con jinete utilizando una de las cabezas mencionadas (v. supra nota 40) forma parte de un documental didáctico sobre Monte Mozinho: http://ensina.rtp.pt/artigo/o-castro-de-monte-mozinho/ (consulta el 5.2.2018). La película muestra asimismo la reconstrucción de un caballo sin jinete en $3 \mathrm{D}$ en un pabellón con cuatro columnas.

151 Bergemann, 1990, 26 y cap. IV.

152 Bergemann, 1990, 17.
Galia y de Germania ${ }^{153}$. En general son de tamaño notablemente inferior al natural con alzadas que, cuando se pueden medir, oscilan entre aproximadamente 60 y $70 \mathrm{~cm}^{154}$. En este contexto cabe remitir al conocido ejemplar de chapas de hierro de Manching ${ }^{155}$, a los fragmentos de bronce de Tintignac $^{156}$, al conocido caballo de bronce de Neuvyen-Sullias ${ }^{157} y$, por último, a dos cabezas de caballo de Eysses/ Villeneuve-sur-Lot, Aquitania ${ }^{158} \mathrm{y}$ Stanwick/Yorkshire ${ }^{159}$. La situación cronológica de estas piezas es La Tène media del siglo III/II a. C. (Manching) ${ }^{160}$, La Tène tardía del siglo II/I a. C. (Tintignac) ${ }^{161}$, la época de transición (Eysses y Stanwick ${ }^{162}$ ) y el siglo II d. C. (Sullias) ${ }^{163}$.

La comparación de las estatuas de caballos del arte ibérico, hispano-noroccidental, celta y celtoromano presenta a primera vista similitudes y diferencias. Un rasgo común a todas ellas es el tamaño inferior al natural, más notorio en unos casos que en otros, aunque las diferencias afectan sobre todo al material. Las esculturas hispanas están esculpidas en la piedra local -piedra caliza en el arte ibérico y granito en el arte de los castros-, mientras que el arte celta y celto-romano de Germania y la Galia utiliza sistemáticamente metal. La producción de

153 Aquí no se han tenido en cuenta las imágenes de caballos guiados, como las que aparecen, por ejemplo, en un relieve en piedra caliza de Lyon, pertenecientes a la época imperial, v. Fellague, 2016, 302-304, que quizá hayan tomado el repertorio formal de los relieves griegos orientales, v. Pfuhl y Möbius, 1979, lám. 208-212. Resumen sobre la importancia del caballo en el mundo celta, p. ej., Müller, 1990, 157-163.

154 En este contexto quizá puedan omitirse las pequeñas estatuillas de bronce de caballos, de las que se conocen ejemplos procedentes de Pogny/Marne (Lantier, 1939, 239), Guerchy/Yonne (Corot, 1925, 6), entorno de Lyon/Rhône (Reinach, 1894, inv.14699), Jœuvres/Loire (Déchelette,

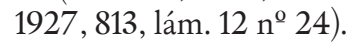

155 Krämer, 1989; Sievers, 1991, 153.

156 Maniquet, 2005; Maniquet, 2008, 300-302 Figs. 28, 30 y 32; Maniquet, 2016, 134 Fig. 2, 4.

157 Espérandieu, Recueil IV 2 (1911) 119 n 2978; Debal, 1974, 88-97, Fig. 31-33; Duval, 1977; Krämer, 1989, 538, Fig. 14. 15; Birkhan, 1999, 272; Catálogo, 2007.

158 Garnier, 1992, 102-104.

159 Duval, 2009, 30, Fig. 2. Debido a su formato de estatuilla, no se ha tenido en cuenta una pieza de bronce de París, v. Varagnac, 1956, 147 nº 56. 58.

160 Krämer, 1989, 531.

161 Maniquet, 2016, 316 s. (depositado en la segunda mitad del siglo I a. C.).

162 Garnier, 1992, 102-104, Fig; Duval, 1977.

$163 \mathrm{~V}$. bibliografía en nota 157 . 
estatuas a base de chapas preformadas y soldadas representa, sin duda, una particularidad.

Ante este trasfondo, ¿dónde cabe situar el monumento de Munigua? Tanto por su tamaño natural como por el uso del bronce ocupa evidentemente una posición excepcional. Ambas características son inusuales en el arte ibérico, apuntando en cambio al arte romano, donde representan la situación normal $1^{164}$. De otro lado, y en contraposición a los ejemplos romanos, el caballo de Munigua está en posición de pie, estático, es decir, no realiza ningún movimiento, como suele ser habitual en las estatuas ecuestres romanas ${ }^{165}$ : ni tiene las dos patas delanteras en alto ni está andando ni levanta un casco delantero (Sullias). La posición de pie, con las cuatro patas en el suelo, aparece, sin embargo, en la estatua descrita de Manching ${ }^{166} \mathrm{y}$, atendiendo a su procedencia prerromana, es posible que el caballo de bronce de Tintignac también estuviera en esa misma postura, ya que los tres fragmentos que se conservan corresponden a una postura de la pata estirada - no curvada-, lo que apunta a que el animal estaba de $\mathrm{pie}^{167}$. Todo parece indicar que en el arte celta los caballos se representaban con las cuatro patas apoyadas, y esa es la postura que adoptan también los caballos ibéricos mencionados ${ }^{168}$. De acuerdo con ello y en lo que atañe a este motivo, es evidente que existe una tradición prerromana más antigua y también otra ibérica, en la que encaja la estatua del caballo de Munigua.

Por lo que se refiere al contexto del emplazamiento original de todas estas estatuas, el de $M u$ nigua se conoce perfectamente. El golpe de suerte estriba en la localización del santuario en el foro y en la inscripción en la que se describe la dedicatoria (figura 10), como se ha expuesto en lo que antecede. De acuerdo con la información disponible, las

164 Bergemann, 1990, 19.

165 Cf. Bergemann, 1990, láminas.

166 Krämer, 1989, 529, Fig. 8 (reconstrucción).

167 Maniquet, 2008, 300-302, Fig. 28, 30 y 32; Maniquet, 2016, 134, Fig. 2,4.

$168 \mathrm{El}$ motivo en sí proporciona al parecer una referencia cronológica. Mientras que la tendencia apunta a considerar los caballos en posición de pie como prerromanos, los animales que se representan en movimiento pertenecen a la época romana. La transición de un motivo a otro tuvo lugar seguramente de forma progresiva. Entre las numerosas piezas de Ilurco (Pinos Puente, Granada) figura un ejemplar representativo de ese periodo de transición. El caballo está de pie, pero lleva una inscripción en latín, v. Rodríguez Oliva, 1983, 758, lám. 7,1. piezas celtas proceden de un depósito secundario en santuarios, lugar del que proceden también en general los ejemplares ibéricos (p. ej. Cigarralejo).

La investigación se ha preguntado siempre cuál era el significado de las estatuas de caballos y su relación con las divinidades veneradas en los santuarios $^{169}$. Desde un punto de vista puramente teórico se abren tres posibilidades ${ }^{170}$. La figura del caballo representaba a la propia divinidad, siendo esta su forma original (1); el caballo podría ser el atributo de una divinidad (2) y, por último, cabría pensar también en la posibilidad de que se representara una escena mitológica, en la que el caballo desempeñara un papel, igual que la divinidad (3).

En Munigua, la posibilidad número 3 parece la más improbable, pues la escultura no representa a un grupo de figuras, sino tan solo al caballo, sin ningún otro actor. Ciertamente, las imágenes de Dis Pater son muy escasas y solo se conocen las procedentes de Etruria, donde su uso está limitado al contexto funerario. En estos relieves, Dis Pater aparece entronizado en compañía, aquí, de la Aeracura etrusca ${ }^{171}$. Frente a la escasa presencia epigráfica y arqueológica en los hallazgos -y de ahí la poca importancia de la divinidad en Roma ${ }^{172}$ destaca su difusión en las provincias celtas y, en particular, en la Galia. Esta circunstancia no obedece tanto a los testimonios gráficos y epigráficos que figuran entre los hallazgos como, ante todo, al hecho de que Julio César incluyera a Dis Pater en la relación de los dioses romanos que tienen su correspondencia en la cultura celta (Caes., Bell. Gall., VI, 17). A ello se suma la afirmación de que los druidas creían que el dios del inframundo, esto es, Dis Pater, era el padre de todos los galos (Caes., Bell. Gall., VI 18,1: Galli se omnes ab Diti patre prognatos praedicant). La divinidad aparece mencionada con mucha frecuencia en la bibliografía especializada correspondiente.

169 Por ej. Krämer, 1989, 539.

170 Por ej. Maniquet, 2016, 133s.

171 LIMC III 1 (Zúrich, Múnich 1986), 644 s. v. Dis Pater (Belloni).

172 El motivo podría ser la equiparación con Pluto, del que había muchas más imágenes (LIMC IV 1 [Zúrich 1988], 399-406 s., v. Pluto (Lindner); Dis Pater es "Pluto italianizado", v. Roscher 1884-1890, 1179 (Peter). Dis Pater tenía un altar al pie de la colina del Capitolio y en su honor se sacrificaban animales de color negro, v. RE XXI 1 (Stuttgart 1951), 1005 s., v. Pluton (Wüst); DNP III (Stuttgart 1997), 689 (Graf). En lo que atañe a los sacrificios, v. Scheid, 2014, $30 \mathrm{~s}$. 
En la posibilidad número 2, estas consideraciones llevan a preguntarse por la función que el caballo, en cuanto atributo, tenía para Dis Pater. Ante la falta de paralelismos, dicha función no podía ser ni ontológica ni fenomenológica. Solo podría darse un paralelismo ontológico si hubiera otras estatuas en las que se representara a Dis Pater con la figura de un caballo. El dios aparecería entonces como un caballo, el propio dios sería un caballo. En este sentido, tampoco fenomenológicamente puede ser representado como un dios con rasgos antrópicos y sus atributos correspondientes. La hipótesis de una función atributiva se basaría en un argumento ex silentio; el santuario del foro de Munigua sería el primer ejemplo de un caballo como atributo de Dis Pater. Asimismo, representaría una ampliación del espectro tradicional del significado del caballo en el arte y la mitología grecorromanos, documentado, de una parte, en temas relacionados con la guerra, la lucha y la agonía y, de otra parte, como atributo de los Dioscuros, pero también de Helios, de Poseidón Hippios o Neptuno Equestre, de Atenea, de Ares $y$ de Hera ${ }^{173}$. La existencia en Munigua de un santuario dedicado a Dis Pater tiene una explicación convincente: la ciudad vivía de las minas, que eran su principal actividad económica ${ }^{174}$, por lo que no debe extrañar que se hablara constantemente de lo que sucedía bajo tierra $y$, menos aún, del dios que gobernaba ese inframundo.

Con ello, solo queda la posibilidad número 1: la divinidad posee la forma de un caballo. De las dos lecturas de la inscripción mencionadas con anterioridad, en este punto cobra fuerza la lectura adjetiva que Grünhagen hace de las dos palabras centrales equilem aedem. Epigráficamente, en tal caso, solo se menciona un edificio, designado además como aedes. Esta interpretación coincidiría con el hallazgo arqueológico: un edificio como morada del caballo, la estatua estaría alojada en su templo. Como el espacio es pequeño, lo ocuparía prácticamente por completo. Suponiendo que el zócalo (medidas 0,91 m x 2,2 m) estuviera situado más o menos en el centro del habitáculo, de aproximadamente $2,6 \mathrm{~m} \times 3,80 \mathrm{~m}$, resultaría un pasillo estrecho a ambos lados de aproximadamente de $0,80 \mathrm{~m}$ y de $0,90 \mathrm{~m}$ delante y detrás (figura $7 \mathrm{~b})$. Al rodear el monumento, los fieles no podrían

173 Resumen en Müller, 1990, 155; DNP 9 (Stuttgart, Weimar 2000), 702 s., v. caballo (Raepsaet).

174 Schattner, Ovejero Zappino y Pérez Macías, 2004. moverse cómodamente entre la pared exterior y el zócalo, sino que tendrían que girar el cuerpo. Si el zócalo se colocaba pegado a la pared posterior, habría más espacio en la entrada, pero no se podría caminar alrededor del monumento (figura 7) ${ }^{175}$. En cualquier caso, el acceso al habitáculo estaba restringido a muy pocas personas, si es que estaba autorizado. Igualmente incierto resulta el emplazamiento del altar donde se celebraría el culto.

Delante del templo hay cuatro piedras sin una forma determinada (arenisca), dos más grandes y dos más pequeñas. Cada una de ellas posee una especie de base cuadrada cuyo borde inferior está rodeado por una franja plana vertical. La altura permite conocer la profundidad a la que las piedras estaban insertadas en el suelo. La cara inferior es plana, definiéndose así la superficie útil (figura 12a y 12b). Cuando a principios de los años 80 del siglo pasado se construyó el muro de contención en el lado este del foro, se rellenó o, en su caso, se elevó el suelo (y con ello las cuatro piedras) desde un nivel situado unos $80 \mathrm{~cm}$ más abajo hasta el nivel actual, manteniendo estrictamente la posición y orientación originales ${ }^{176}$. Esta medida se adoptó porque en el suelo se veía la cara superior de las piedras más grandes. Las piedras se encontraban (y se encuentran de nuevo) exactamente delante de los intradoses de la puerta de entrada al santuario, con el que parecen que tenían algún vínculo. Como la citada franja plana termina siempre en la cara norte, es posible que las piedras estuvieran en contacto directo con un muro, probablemente con el frente del santuario de Dis Pater. Al proceder a su elevación, se hizo visible la forma. Frente a la forma plana lenticular de las dos piedras más pequeñas, las dos más grandes no tienen una forma definida o se van estrechando, lo que puede ser consecuencia de la erosión natural de la arenisca, ya que falta cualquier huella de uso. Por su forma se excluyen como material de construcción. Tampoco estaban colapsadas, sino todo lo contrario, al parecer, se encontraban incluso in situ. ¿Cuál era su función? En mi opinión, podrían interpretarse como hitos que marcaban los límites del espacio, como es de esperar en un santuario. Por sus formas inusuales e incluso llamativas, podrían ajustarse muy bien a ese uso. Como ya

$175 \mathrm{Tal}$ como afirma von Hesberg, 2007, 456, en la colocación de la base del culto se aprecia inequívocamente una tradición griega o romana.

176 Sobre la construcción del muro v. Hauschild, 1986, 325. El nivel inferior es el nivel del suelo del recinto precedente, v. Schattner, 2017a, 129 s., Fig. 3. 
se encontraban en esa posición en el nivel inferior, una explicación podría ser presumir que cuando el santuario de Dis Pater estaba en uso, el horizonte del suelo se encontraba en ese nivel inferior y que las piedras desempeñarían también la función de hitos en el santuario más antiguo, que estaría situado debajo del conocido ${ }^{177}$. Si esta hipótesis es correcta o, al menos, probable, la conclusión sería que la extensión del santuario estaba limitaba al supuesto espacio que ocupa en el foro, donde tendrían que haberse depositado posibles ofrendas votivas (también para otras divinidades), de las que en Munigua no se ha encontrado el menor rastro en los 60 años de investigación de campo. De ello se deduce que la estatua del caballo era, con gran diferencia, el monumento más grande del santuario. Por su tamaño y por el hecho de ser de bronce -podemos imaginar que estaría pulido o incluso dorado ${ }^{178}$-, debía causar un efecto impactante e infundir respeto, admiración, consideración y también fervor religioso. Al estar colocado sobre un zócalo de la altura de un hombre generaba distancia, apartándose así del ámbito mundano, a la vez que la postura estática acentuaba su inmovilidad ${ }^{179}$. Para apreciarlo en toda su magnificencia había que situarse en el pórtico, es decir, muy cerca de la puerta del sacellum, y mirar hacia arriba ${ }^{180}$. El habitáculo alto y estrecho, unido al vano de la puerta, que determinaba la anchura tanto del espacio como del santuario, contribuía en cierto modo a centrar la mirada en el caballo, reforzando así el efecto correspondiente. La reconstrucción de la figura $9 \mathrm{~b}$ intenta visualizar la situación, la distancia que separa al observador de la puerta depende del tamaño del vano. Si el observador quería ver la estatua completa, apenas podía cambiar de posición ${ }^{181}$. Todas estas características se corresponden con los hábitos grecorromanos de ver las imágenes de los dioses en general y de las estatuas

177 En este lugar estaría indicada una excavación para verificar la situación.

178 En Munigua hubo estatuas de bronce doradas, v. Krug, 2006, 154 Fig. 1a; el grupo escultórico de Perugia puede ayudar a hacernos una idea, v. Andreae, 2012, 226 s. Fig. 166.

179 Las características se corresponden con la lista de peculiaridades que distinguen a las imágenes de divinidades romanas, v. von Hesberg, 2007, 444.

180 Sobre las manifestaciones de lo divino v., p. ej., Versnel, 1993.

181 En esta relación axial puede reconocerse un efecto de la perspectiva frontal de la plástica helenística, v. von Hesberg, 2007, 456. de culto en particular ${ }^{182}$. Gabriele Nick ha descrito recientemente las características de una estatura de culto (griega) utilizando como ejemplo la de Atenea Partenos ${ }^{183}$. De acuerdo con ello, las imágenes de culto son "imágenes de divinidades que están relacionadas directamente con un acto ritual" o que están fuertemente arraigadas en $\mathrm{el}^{184}$. Como se ha expuesto, esta situación se da en Munigua a pesar de que no sea posible documentar directamente el ceremonial propio del culto al faltar los testimonios pertinentes, como, por ejemplo, el altar. No obstante, es muy probable que se celebraran actos rituales, tal como se desprende del espacio que la estatua ocupaba en el templo (figura 7 b. c; 9b). Atendiendo a todas estas posibilidades descritas, todo parece indicar que el caballo era la estatua de culto en el santuario Dis Pater de Munigua ${ }^{185}$. Por todo ello, podemos suponer con razón que se trata de un hallazgo que abre grandes posibilidades a un debate riguroso, a su denominación y a la reconstrucción del recinto, junto con su estatua de culto.

Ahora bien, ¿el caballo es realmente la personificación de la divinidad? ¿La estatua equina encarna a Dis Pater? En otras palabras, ¿el significado "Dis Pater" es idéntico al significante "caballo" en Munigua? Esta cuestión ocupa un papel central en el debate sobre las imágenes de divinidades no solo en la investigación española ${ }^{186}$. Como punto de partida de todas las reflexiones se utilizan siempre los testimonios gráficos más antiguos procedentes de Hispania, en concreto, relieves en los que se representan caballos simétricamente situados a ambos lados de una deidad masculina según el conocido esquema del señor de los animales (posis hippon) ${ }^{187}$. Tradicionalmente, la investigación ha reconocido siempre al caballo en el arte ibérico un carácter atributivo. La divinidad se consideraba una diosa de la fecundidad, a la que protegían los caballos ${ }^{188}$. Las

182 Un esclarecedor resumen actual sobre esta cuestión de la mano de ejemplos griegos en Klöckner, 2012.

183 Nick, 1997; Nick, 2002.

184 Nick, 1997, 22 s.

185 Fernández Chicarro y Collantes de Terán, 1972-74, en cambio, parten de una ofrenda votiva.

186 Contexto celta: p. ej. Krämer, 1989, 538 s.; contexto hispano, p. ej., Fernández Gómez, 2003, 35 (con bibliografía más antigua).

187 Resumen, p. ej., en Blázquez Martínez, 1977, 290 306, Fig. 95-107; Chapa Brunet, 1980, 878-889; Fernández Gómez, 2003, 38; Almagro-Gorbea, 2006, 64 s., Fig. 2.

188 Blázquez, 1973, 756; Blázquez Martínez, 1975, 148: "a una diosa de la fecundidad, con el matiz concreto de la 
últimas investigaciones han llegado, sin embargo, a otra conclusión, según la cual, en la península ibérica, el caballo encarnaba a una deidad que se veneraba en todo el Mediterráneo ${ }^{189}$ y en cuyo culto los iberos participaron a su manera ${ }^{190}$. Sin embargo, esta teoría ha sido refutada recientemente, y los autores correspondientes han vuelto a sacar a la luz la hipótesis tradicional del carácter atributivo del caballo ${ }^{191}$. A pesar de su extraordinario interés arqueológico y epigráfico, el hallazgo de Munigua no ha desempeñado hasta ahora ningún papel en este debate y ni siquiera se menciona, lo que no deja de ser cuando menos sorprendente ${ }^{192}$. La causa quizá se deba a su datación tardía, en la época romano-imperial ${ }^{193}$, a la que, al parecer, no se le reconoce suficiente valor informativo. Sin embargo, en Hispania hay otras referencias a divinidades que adoptaban la figura de un caballo, lo que respalda la interpretación del hallazgo de Munigua. Epigráficamente relevante es el ara votiva de la provincia de León que un tal Iulius Reburrus dedicó a los dei

divinidad protectora de los caballos a la que se ofrecían exvotos de estos animales como devoción típica".

189 La idea se remonta a Bênoit, 1950, 40-48.

190 Chapa Brunet, 1980, 888, piensa en una divinidad con figura de caballo, protectora de estos animales. Ya desde el comienzo de su artículo, Ramos Fernández, 1993, aboga por la transformación del caballo en cuanto atributo en la divinidad propiamente dicha. La divinidad era masculina y el caballo, su atributo. Era un dios de la fecundidad, encargado de proteger la fertilidad de los campos y, por tanto, también de la gleba y de la guerra, pues las guerras se hacían para defender la tierra de cada uno, es decir, se trataba del dominio del suelo y de la tierra, de pretensiones territoriales. En un segundo paso, la figura del caballo materializaría esa idea de divinidad, dando así origen a la idea de un "dios-caballo". Los caballos sin jinete ni montura de la escultura ibérica son, según este autor, la personificación de esa deidad.

191 Olmos Romera, 1992, 29 s.; Aranegui y Prados, 1998, 156; Quesada Sanz y Gabaldón, 2008. Estos autores basan su argumento sobre todo en los citados relieves con imágenes del posis hippon. En el arte ibérico, el caballo tiene siempre carácter atributivo sobre todo en contextos bélicos o procesionales como elemento de prestigio. Los relieves votivos con imágenes de equinos tenían esa misma función atributiva. Los caballos solos acompañaban a las almas de los difuntos, mientras que los caballos sin jinete, pero embridados, implicaban siempre un guía a pie.

192 Una excepción es Bendala Galán y Quesada Sanz, 1995, 64 con su defensa del carácter atributivo del caballo (“...consagración al diós de un caballo...”), es decir, como animal sacrificado.

193 Por ejemplo, Moneo, 2003, que concluye su investigación en el siglo I a. C.
Equeuni y puede interpretarse del mismo modo ${ }^{194}$, y otro testimonio epigráfico es quizá el nombre del dios Equeisos ${ }^{195}$. Otra referencia al caballo se esconde también en el epíteto Equotullaicensis referido a Arentia, procedente de Sabugal (Portugal) ${ }^{196}$. Arqueológicamente se ha hallado también el paralelismo de un caballo como imagen de culto en el yacimiento celtibérico de Azaila (Cabezo de Alcalá, provincia de Teruel). Hace aproximadamente un siglo, en el curso de las excavaciones se encontraron fragmentos de bronce que pueden asociarse tanto con un caballo como con una figura masculina en una céntrica construcción de la ciudad romana. El pequeño edificio se caracteriza, de una parte, por la presencia de antas y, de otra, porque la mitad del espacio interior está ocupado por un podio (altura $81 \mathrm{~cm})^{197}$. Sobre la base de las marcas existentes en el podio es posible reconstruir un grupo escultórico en el que un soldado guía a un caballo (figura 13) ${ }^{198}$. Como otra cabeza femenina que también se ha encontrado no presenta ninguna muesca, se supone que la figura estaba suspendida en el aire coronando al soldado a modo de una Nike/Victoria ${ }^{199}$. Junto con el edificio correspondiente, el grupo escultórico cumple todos los requisitos de una imagen de culto en un templo, y así debe interpretarse, sobre todo porque también se ha descubierto el altar in situ, delante del podio ${ }^{200}$. En un primer momento, este hallazgo puede equipararse con el ejemplo muniguense porque el edificio que supuestamente albergaba el santuario está construido en forma de templo con antas, si bien los dos bloques que las conforman no están unidos a los muros, sino tan solo antepuestos, dando así lugar a un pórtico pavimentado con losas de mármol de distinto tamaño (figura 7)201. El tamaño de las estatuas es asimis-

194 Marco Simón, 1999.

195 En la lectura de De Hoz, 1995, 22. Otra lectura como apodo del dios Lug en Meid, 1994, 37, que, al parecer, se ha impuesto, v. Marco Simón, 1999, 485; Quesada Sanz y Gabaldón Martínez 2008, 158.

196 Peñalba de Villastar: resumen Marco Simón, 1999, 484, con nota 15. Sabugal: resumen Marco Simón, 1999, 484 , con nota 16.

197 Cabré, 1925, 309-312, Fig. 13; Beltrán Lloris, 1976, 151, Fig. 39; Beltrán Lloris, 2000, 230-236, 384 s.

198 Beltrán Lloris, 1976, 151 s.y 155-166, lám. 5; Beltrán

Llloris1996, 159-161 (reconstrucción en color p. 160). 199 Nony, 969, 24.

200 Cabré, 1925, 310-312, Fig. 13; Beltrán Lloris, 1976, 164.

201 En el curso de las citadas obras de restauración en el 
mo similar, y el del ejemplar de Azaila es incluso superior al natural ${ }^{202}$. Como consecuencia, también se asemeja la proporción entre las estatuas y los edificios. En Azaila, la cella, que mide 6,05 x 4,10 $\mathrm{m}$, parece igualmente pequeña y el grupo escultórico situado encima del podio debía de producir un efecto de encajonamiento (figura 13) ${ }^{203}$. En cuanto al interior del habitáculo, en Munigua faltan hallazgos testimoniales, pero es lógico imaginarse que las paredes estarían estucadas y decoradas con pinturas, como era habitual; es posible que el suelo fuera de mármol, como en el pórtico, o estuviera decorado con un mosaico. En Azaila en cambio se han conservado tantas cosas, que es fácil reconstruir el interior: el suelo delante del podio estaba cubierto por un mosaico en el que teselas blancas simulaban un laberinto sobre una base de color; las paredes estaban estucadas y decoradas con un motivo geométrico; en el pronaos había otro mosaico con un motivo de escamas ${ }^{204}$. En realidad se trata de la decoración habitual del interior de los templos republicanos en Italia ${ }^{205}$.

Hasta no hace mucho tiempo, el monumento de Azaila se databa habitualmente hacia la mitad del siglo I a. C. ${ }^{206}$; sin embargo, la investigación más reciente ha datado el recinto, con fundamentos sólidos, en el año 70 a. C. como terminus ante quem ${ }^{207}$. Esta fecha ha generado un conflicto con la datación del grupo escultórico, pues el análisis estilístico de la cabeza masculina la sitúa por lo general en una fecha posterior, hacia el año 30 a. C. ${ }^{208}$. Azaila fue abandonada definitivamente a principios del segundo cuarto del siglo I a.C. (75/74-69/68 a. C.), tal como ha demostrado el estudio detallado de los hallazgos y las característi-

foro el hallazgo se fijó con mortero.

202 Nony, $1969,5$.

203 El grupo escultórico se ha colocado más o menos en el centro del podio con un ligero desplazamiento hacia la entrada, v. Nony, 1969, 6.

204 Cabré, 1925, 310; Jaeggi, 1999, 219, nº 149, Fig. 56. Estado actual según Beltrán Lloris, 2000, 384-392 con referencia a la datación del mosaico o la decoración de la pared en el primer estilo, es decir, a principios del siglo I a. C.

205 von Hesberg, 2007, 451.

206 Nony, 1969, 25; Beltrán Lloris, 1976, 164. Esta datación se basa en primer lugar en circunstancias históricas externas, como la destrucción de la ciudad tras la batalla de Ilerda en el año 49 a. C.

207 Beltrán Lloris, 2000, 392.

208 Por ej. Trillmich, 1993, 55 lám. 35. La dilatada historia de la investigación descrita con detalle en Nony, 1969, 8-15; Beltran Lloris, 1976, 158 s.; Beltrán Lloris, 2000, 388 s. (con todas las dataciones y descripciones).

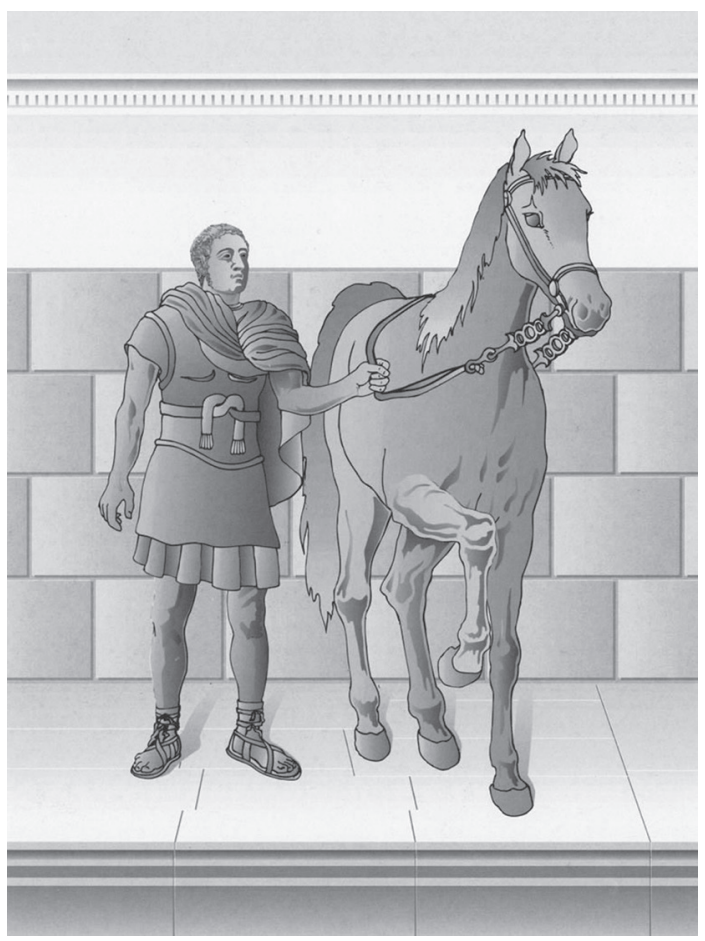

Fig. 13. Azaila, grupo escultórico de culto, reconstrucción M. Beltrán Lloris. (Fig. 13 Según Beltrán Lloris 1996, 160 Fig. 152 (reconstrucción M. Beltrán Lloris)

cas $^{209}$, por lo que hay que distanciarse de la datación estilística tardía en favor de otra más temprana. La alternativa sería rechazar la hipótesis de la construcción simultánea del templo y las estatuas y aceptar los datos descritos como ciertos. En esta constelación, el resultado sería que el templo habría permanecido sin estatuas durante una generación.

Mientras Nony vio en la totalidad del recinto la tumba de un joven aristócrata fallecido, remitiéndose a ciertos paralelismos de la época helenística ${ }^{210}$, en 1976 Beltrán Lloris sugirió el nombre de Quintus Iunius Hispanus ${ }^{211}$, si bien más tarde aludió a un caudillo indígena anónimo ${ }^{212}$. Almagro-Gorbea pensó en primer lugar en un dios patrón de la ciudad, más tarde en un héroe fundador y, por último, en un héroe local ${ }^{213}$. Tal como ilustra el ejemplo de los camafeos, en los que probablemente Cneo Pom-

209 Beltrán Lloris, 2000, 488.

210 Nony, 1969, 25; ibídem Mierse, 1999, 129 (con la presunción de que Sertorius está representado en ella) y Beltrán Lloris, 2000, 389.

211 Beltrán Lloris, 1976, 163

212 Beltrán Lloris, 1996, 161 ("jefe indígena").

213 Almagro-Gorbea, 1994, 32 ("templo poliádico"); Almagro-Gorbea, 1996, 128 ("heros ktistes"); Almagro-Gorbea 2006, 82 ("Heros"). 

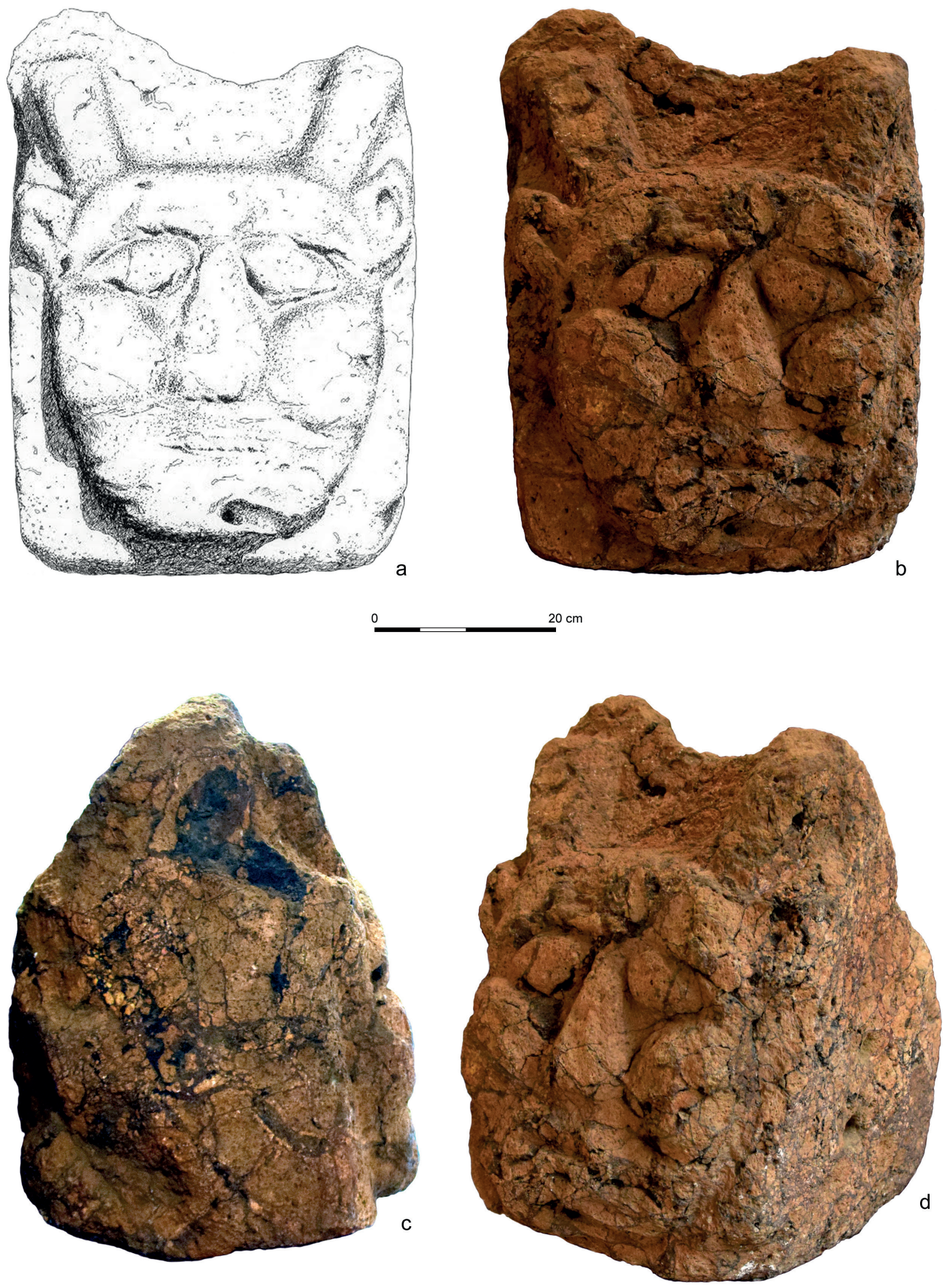

Fig. 15. Río Tinto, Museo Minero. Demonio A. (Fig. 15. 16. Dibujos de Antonio López Domínguez; fotos cedidas amablemente por Aquilino Delgado, procesado DAI Madrid (E. Puch Ramírez)) 

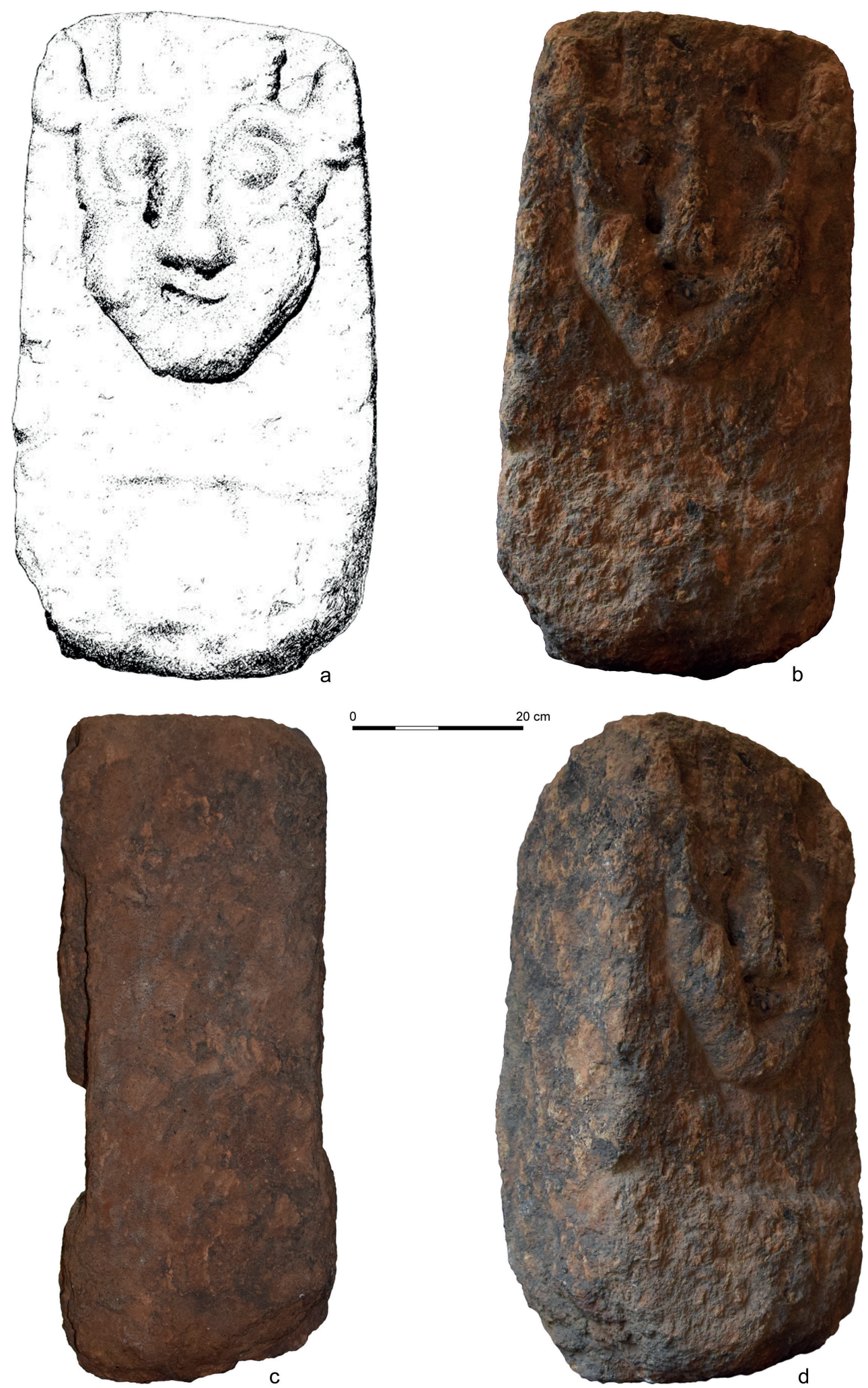

Fig. 16. Río Tinto, Museo Minero. Demonio B. (Fig. 15. 16. Dibujos de Antonio López Domínguez; fotos cedidas amablemente por Aquilino Delgado, procesado DAI Madrid (E. Puch Ramírez)) 
peyo Magno se hizo representar como dioscuro, a principios del siglo I a. C. quizá era posible retratarse con atuendo divino. Según es sabido, también C. Metelo se hizo coronar en Corduba por una Nike utilizando un ingenio mecánico ${ }^{214}$.

A los monumentos anteriores y fuera del ámbito hispano se suma la mencionada estatua del caballo de Sullias del siglo II d. C., que según reza la inscripción estaba dedicado al dios Rudiobus. Desde hace tiempo, la investigación debate sobre si se trata de una ofrenda votiva o de una estatua de culto $^{215}$. Atendiendo al formato y a las cuatro anillas de bronce móviles del zócalo parece tratarse de un artilugio que desempeñaba algún papel en el culto y, por ejemplo, podía sacarse en procesión. La pregunta sobre de si se trataba de una estatua de culto es preferible dejarla abierta ${ }^{216}$. También la mencionada estatua de Tintignac se ha considerado una imagen de culto, sin que se hayan aportado argumentos convincentes ${ }^{217}$.

Los monumentos descritos delimitan el marco cultural en el que surgió la imagen de Dis Pater en la figura de un caballo. Se trata sin duda de una creación innovadora muy similar a la imagen del dios Endovélico, descrita en lo que antecede ${ }^{218}$. Técnicamente, es posible que las estatuas ecuestres romanas sirvieran de modelo para la estatua del caballo, ya que, por lo general, son de tamaño natural y en Hispania se conocían desde principios de la época imperial ${ }^{219}$. En cuanto al significado, la decisión para erigirla pudo partir de la propia Munigua, ya que los escasos testimonios de la presencia de Dis Pater en la península ibérica son meramente epigráficos, además de estar muy diseminados y lejos unos de otros (figura 14).Junto al testimonio de la bética Munigua hay otro de Extremadura, concretamente de Burguillos (Badajoz), así como dos inscripciones de la meseta en Carrascosa de Henares (Guadalajara) y de Espeja de San Marcelino

214 Vollenweider, 1972-74,43 s., $\mathrm{n}^{\mathrm{0}}$ 68,1; 44, $\mathrm{n}^{\mathrm{0}}$ 69,4; Beltrán Lloris, 2000, 389, Fig. 289 y 290.

215 Krämer, 1989, 538 s. (historia de la investigación).

216 Así también Krämer, 1989, 538, que no se manifiesta.

217 Maniquet 2008, 319 (“...utilisation comme statues de culte ne peut être écartée”); más precavido, sin embargo, en trabajos recientes, Maniquet 2016, 138 (“...le cheval, le cygne...symboles eschatologiques forts...”).

218 V. supra, capítulo sobre el dios Endovélico (figuras 5 y 6$)$.

219 Bergemann, 1990, 19. 39.
(Soria) ${ }^{220}$. Más allá del significado local descrito, el Dis Pater de Munigua es ante todo una divinidad tópica de marcado carácter local.

Las explicaciones precedentes han puesto de relieve las distintas corrientes que confluyen en el caballo de Munigua en cuanto imagen de culto. La comparación con la imagen de Azaila revela diferencias fundamentales, que afectan en primer lugar al motivo y después a la forma de la base de la imagen: en Munigua es un zócalo o podio de granito, mientras que en Azaila ocupa todo el ancho de la cella. Von Hesberg ha calificado semejante disposición de ilustrativa ${ }^{221}$ y en combinación con el motivo del soldado y el caballo en movimiento acentúa el efecto de la presencia inmediata de la divinidad $^{222}$. Todo lo contrario de lo que ocurre en Munigua, donde la altura del zócalo, la manera de dirigir la mirada hacia el monumento y la estrechez del habitáculo aleja la estatua del espectador, por lo que necesariamente tenía que parecer inaccesible. Los dos santuarios tienen, sin embargo, en común que tanto en Azaila como en Munigua tan solo un número muy reducido de personas podía acceder a la divinidad.

Por los detalles expuestos, no hay que dar por hecho que detrás del Dis Pater muniguense se esconda necesariamente una divinidad indígena, como supuso Grünhagen ${ }^{223}$. Esta hipótesis no puede fundamentarse mientras no se aclare cómo es posible que en Munigua no exista ningún santuario prerromano dedicado a una divinidad con apariencia de caballo.

\section{Los demonios de Río Tinto (figuras 15 y 16)}

Como último ejemplo mencionaremos los dos relieves con demonios de Río Tinto, cuya localización describió brevemente William Giles Nash en 1904. Sin embargo, fue Antonio Blanco Freijeiro el primero que la publicó en 1962 (figuras 15 y 16) 224 .

220 Carrascosa: Gimeno Pascual, 2008, 276; GómezPantoja, 2008, 44, n 74; Gamo Pazos, 2012, 42; Espeja: Hernando, 2008, 82 s., nº 123; Burguillos: Gómez-Pantoja, 1997, 25, $\mathrm{n}^{\circ}$ 51, amable indicación de A. U. Stylow, a quien doy las gracias.

221 Von Hesberg, 2007, 458.

222 Von Hesberg, 2007, 459.

223 Grünhagen, 1976, 237.

224 Nash, 1904, 60; Blanco Freijeiro, 1962, 39-41 lám. 2, Fig. 10 y 11; Blanco Freijeiro y Luzón Nogué 1966, 79; Blanco Freijeiro, Luzón Nogué y Ruiz Mata 1970, 7 s.; Blázquez Martínez,1973, 755; Blázquez Martínez, 1975, 82-84 Fig. B. E; Delgado Domínguez, 2006, 206 s.; Pérez 


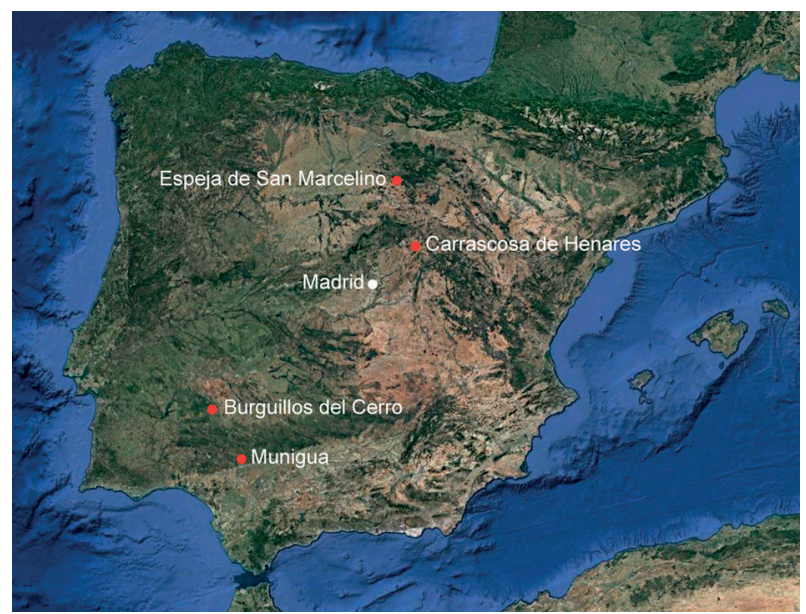

Fig. 14. Difusión de las pruebas (epigráficas) de Dis Pater en la Península. (Fig. 14 DAI Madrid, montaje E. Puch Ramírez)

El hallazgo en sí consiste en piezas diseminadas por la ladera norte del Cerro Salomón en Río Tinto (provincia de Huelva) ${ }^{225}$, que por lógica ya debían ser conocidas desde 1887, fecha en que Nash visitó las minas de Río Tinto. Antes del año 1932, los relieves fueron trasladados al museo local ${ }^{226}$, pues David Williams los describe en su inventario de 3 de febrero de 1932 227 . Cuando en 1962 Blanco Frei-

Macías, 2009, 351-353; Fernández Götz, 2009, 179; Delgado Domínguez y Pérez Macías, 2014, 412. - Mi agradecimiento a Elisabeth Truszkowski/Aix-en-Provence por la confianza demostrada al permitirme leer el inicio de su manuscrito inédito "Les deux stèles de Río Tinto et le Cerro de los Santos".

225 El Cerro Salomón pertenece al Filón Norte de la cuenca minera de Río Tinto y fue explotado sobre todo en la primera mitad del siglo XX, v. Pérez Macías et al., 2008, 306 con Fig. 1 (plano actualizado).

226 Sobre la historia de los museos de Río Tinto v. Delgado Domínguez, 2014, 50-55.

227 Williams, 1932, 8 s.: "Roman Edifices, \&O. The foundations of an ancient edifice, now almost entirely obliterated, can still be observed on the summit of Cerro Salomon. Old writings refer to this building as the 'Castillo de Salomon', but there is evidently some doubt as to whether it was of Phoenician or Roman origin. Nash (p. 60) writes that in 1887, whilst searching in the - apparently -four basement rooms, little larger than cells about eight feet square, the drainage of them was found to have been provided for. The earthenware tiles, semi-circular, forming the spiping for the drainage, of which, concealed in the loose earth, a few still remained entire, were of large size. From this place too, Roman sarcophagi are said to have been obtained. Possibly during the Roman occupation the Castillo de Salomon was used as a stronghold and watch-tower. Buried in the loose soil and debris some short distance below the pinnacle jeiro menciona que, además de los relieves que se estudiarán a continuación, se encontraron también sillares, fustes y basas de columnas ${ }^{228}$, no se refiere a sus propias observaciones, sino a una información anterior. Su afirmación de que en el Cerro Salomón había huellas de asentamientos y objetos de la Edad del Bronce y épocas posteriores que llegan hasta la Edad Media árabe se vio refrendada por las excavaciones de los años 1966/67 ${ }^{229}$, que constataron la existencia de un asentamiento del siglo VII a. C. y una fortaleza árabe ${ }^{230}$. Según el estado actual de la investigación, hay también restos ibéricos y romanos $^{231}$. Los arqueólogos siguieron la hipótesis esbozada por Nash de que los relieves de los demonios podrían pertenecer a la construcción de sillería (que Nash vio y describió) existente en la cima del cerro, de la que incluyeron una foto antigua en su publicación ${ }^{232}$. En 1966/67 no existía ya esa construcción, pues hacía ya mucho tiempo que la cima había desaparecido como resultado de la explotación minera.

Los dos relieves -tanto el demonio $\mathrm{A}^{233}$ como el demonio $\mathrm{B}^{234}$ - muestran rostros grotescos representados de frente (figuras 15 y 16). Esta apariencia, en combinación con el bloque de gossan (silicato de óxido de hierro, conocido también como montera de hierro ${ }^{235}$, de color rojo sangre, que se caracteriza

upon which the 'Castillor was erected, on the northern slopes of the mountain, two curious stone heads or images (see photos) were discovered. Nash states that they appear to be rather crude and inartistic representations of the goddess Ashtaroth, a popular divinity with the Phoenicians, and suggests that they may have been the work of a Phoenician artist" (extracto transcrito del inventario gracias a la amable autorización del Museo Minero de Río Tinto). En el texto se cita la obra de Nash de 1904. Sus dibujos se remontan a 1887, año en que visitó Río Tinto.

228 Blanco Freijeiro, 1962, 39-41.

229 Blanco Freijeiro, 1962, 32. Sobre la mina, v. Domergue, 1987, 237 s. ("filon nord").

230 Blanco Freijeiro, Luzón Nogué y Ruiz Mata, 1970. Sobre el periodo orientalizante en Río Tinto, v. Schattner, 2011.

231 Domergue, 1990, 149 y 169.

232 Blanco Freijeiro, Luzón Nogué y Ruiz Mata 1970, 7 , lám. 4. La fotografía ha sido tomada en el antiguo nivel de la cima de la colina.

233 Blanco Freijeiro, 1962, lám. 2, Fig. 10.

234 Blanco Freijeiro, 1962, lám. 2, Fig. 11.

235 Este material del tipo "gossan transportado" (Pérez Macías, 2009, 351; Delgado Domínguez et al., 2011, 311-314; Pérez Macías et al. 2012, 318; Delgado Domínguez y Pérez Macías, 2014, 412; Delgado Domínguez,2015) se extraía de canteras propias y en la Antigüedad se utilizó para cons- 
por sus numerosas vetas oscuras e inclusiones de grano grueso (cuarzo, entre otras), lo que le confiere un aspecto impuro y en cierto modo repulsivo, produce como resultado una imagen aterradora de la divinidad, que presenta un rostro distorsionado de aspecto demoníaco ${ }^{236}$. Los rostros han sido esculpidos en bloques rectangulares verticales de, aproximadamente, medio metro de altura. Al tratarse de altorrelieves, la superficie del fondo está rebajada. El demonio A es más grande y ocupa casi por completo la superficie delantera del bloque (figura 16). El demonio B es más pequeño (figura 15) y la cabeza sobresale del fondo, que rodea el rostro a modo de superficie plana indiferenciada. Esta superficie es rectangular y hacia los lados presenta un rebaje a modo de marco. En la parte de abajo se ha dejado libre una superficie en la que habría encajado bien una inscripción. Con todo, la proporción entre la cabeza y la superficie parece un tanto desequilibrada, como si faltara algo.

La apariencia grotesca de los rostros se ha conseguido exagerando las partes protuberantes, como los globos oculares, la nariz, los pómulos y los labios. Parece como si cada una de ellas hubiera sido esculpida por separado y solo al unirlas conformaran el rostro. El relieve adquiere así movimiento, a la vez que la incidencia de los rayos de luz y el correspondiente efecto de claroscuro acentúan aún más el efecto. Las características descritas son más notorias en el demonio A que en el B. Sus ojos están bordeados por acanaladuras de aristas vivas y angulosas, confiriéndole un aspecto más terrorífico que en el caso del demonio B, en el que las transiciones son más redondeadas y suaves. Lo mismo cabe decir de las orejas, en el demonio A son puntiagudas y están separadas, mientras que el demonio B carece de ellas. Ambos demonios tienen a cada lado de la cabeza sendas protuberancias de sección cuadrada. En el demonio A se ha eliminado la superficie de fondo entre ellas, en el demonio $B$, en cambio, se ha mantenido. Blanco Freijeiro ha interpretado las

truir monumentos, en concreto, elementos arquitectónicos, como columnas, basas, sillares, altares (Pérez Macías, 2009) y cupae (Pérez Macías y Delgado Domínguez 2012). Desde entonces no volvió a usarse hasta la I Guerra Mundial para extraer el hierro que contiene ante la escasez de este material, v. Pérez Macías, 2009, 362; Delgado Domínguez et al., 2011, 314-323.

236 Naturalmente, es posible que los relieves estuvieran estucados y pintados, e incluso puede suponerse que lo estaban, pero hasta ahora no se han identificado ni huellas ni restos que lo confirmen. protuberancias como cuernos o coronas vegetales estilizadas ${ }^{237}$, que, por otra parte, son muy frecuentes en el arte celta, apareciendo, por ejemplo, en las estatuas de Roquepertuse, Holzgerlingen, Heidelberg, Pfalzfeld ${ }^{238}$ o en el hombre de Glauberg.

Desde entonces se menciona siempre esta conexión con el mundo celta y se relaciona con la presencia en Río Tinto -epigráficamente documentada- de población procedente del norte de Hispania que trajo consigo claras influencias celtas ${ }^{239}$. Es evidente que se trata de figuras míticas. Tal como señala Paul Jacobsthal, la corona de hojas es característica de una divinidad ${ }^{240}$. En el círculo de los monumentos celtas existen, de hecho, paralelismos con estos rostros grotescos, por ejemplo, en los adornos de las asas de bronce de La Tène temprana de Kleinaspergle ${ }^{241}$ y Weiskirchen ${ }^{242}$, así como en una lámina de oro de Schwarzenbach ${ }^{243}$, en la escultura de formato grande del siglo II a. C. de la que la cabeza de Mšecké Žehrovice ${ }^{244}$ es una buena muestra, en algunas imágenes de las deidades representadas en el caldero de Gundestrup del siglo I a. C. ${ }^{245}$, en una chapa de bronce de Cadbury-Camelot ${ }^{246}$, en monedas $^{247}$ y en las imágenes de têtes coupées ${ }^{248}$. Jacobsthal ha demostrado asimismo que la representación de rostros grotescos es característica de la cultura de La Tène temprana ${ }^{249}$.

Con todo, ipertenecen realmente los dos relieves de Río Tinto al entorno del arte celta de Europa Central si se tiene en cuenta que al menos el demonio A, estilísticamente más antiguo, tendría que estar relacionado con una datación en La Tène temprana? A esta hipótesis se opone, en primer lugar, la ausencia de la decoración vegetal que siempre acompaña a las cabezas celtas, así como la inexis-

237 Blanco Freijeiro, 1962, $40 \mathrm{~s}$.

238 Jacobsthal, 1969, 15.

239 Blanco Freijeiro y Luzón Nogué 1966, 83 s.; recientemente Pérez Macías, 2009, 353.

240 Jacobsthal, 1969, 4. 15.

241 Jacobsthal, 1969, 201 n. . 385; Megaw, 1990, 55, Fig. 47. 242 Megaw, 1990, 55, Fig. 48.

243 Jacobsthal, 1969, 171 n. ${ }^{\circ}$ 58; Megaw, 1990, 70, Fig. 74.

244 Varagnac, 1956, 92, nº 1; Megaw, 1990, 124, Fig. 178, lám. 17;

245 Megaw, 1990, 175, Fig. 285; Goudineau y Verdier, 2006, 56 s. 64 y 65.

246 Megaw, 1990, 241, Fig. 412.

247 Méniel, 2006, 176.

248 García, 2006, 160-163.

249 Jacobsthal, 1969, 162: ("The beasts and masks give the Early Style the stamp"). 
tencia de monumentos celtas similares con estatuas de gran tamaño en el sur de Hispania ${ }^{250} \mathrm{y}$, por último, la enorme distancia.

Metodológicamente, parece por ello conveniente hacer un repaso de los monumentos del sur de Hispania, donde de hecho existen muy buenos elementos de comparación. Me remito especialmente a los relieves funerarios de la Alta Andalucía, en concreto, de Linares y de la vecina Úbeda ${ }^{251}$, donde aparecen también los mismos rostros grotescos con protuberancias corniformes ${ }^{252}$, gorgonas con peinados altos, que podrían interpretarse como cuernos $^{253}$, bloques con molduras decoradas con caras que infunden miedo ${ }^{254}$ y rostros que parecen máscaras con hojas de hiedra enhiestas a los lados, que también simulan cuernos ${ }^{255}$. Los dos paralelismos más cercanos tanto por la forma rectangular vertical del bloque de piedra como por la técnica utilizada para representar el rostro hinchando algunas partes quizá sean dos relieves de la colonia romana de Salaria. En uno se muestra un rostro sin barba (igorgona?) con un peinado alto como el que se ha descrito en otras piezas en las que los anchos mechones se disponen a modo de corona ${ }^{256}$; en el otro se acentúa el carácter aterrador de la expresión ${ }^{257}$. Las comparaciones parecen tan convincentes que los relieves de Río Tinto se incluyen inmediatamente en este grupo ${ }^{258}$. Todas las piezas descritas de la Alta Andalucía pertenecen al siglo I d. C. y proceden de construcciones funerarias tipo torre ${ }^{259}$; las dos citadas en último lugar, incluso del mismo monumento, lo que permite suponer la existencia

250 Un posible paralelismo de las cabezas demoníacas mostradas de frente podría verse en la cerámica ibérica de sellos, donde aparecen cabezas similares que se identifican como toros, v. Fernández Maroto et al., 2007, 219, Fig. 7. Sobre este género de cerámica ibérica, imprescindible Blech, 2002/03.

251 Todos ellos son piedra caliza o arenisca local, CSIR España, 2002, 38-43.

252 CSIR España, 2002, 94, v. n 46, lám. 22,1.

253 CSIR España, 2002, 97, nº 48, lám. 24,1.

254 CSIR España, 2002, 99, nº 54, lám. 28,1.

255 CSIR España, 2002, 100, v. n 56, lám. 28,2.

256 CSIR España, 2002, 145, nº 149, lám. 67,1.

257 CSIR España, 2002, 146, v. n 150, lám. 68,1.

258 Otro grupo lo forman las gorgoneia rerpresentadas en los pulvini y altares funerarios del nordeste hispano, que, sin embargo, tienen un formato más pequeño, p. ej. Blech, 1993, 334, v. lám. 118. 119. Su difusión llegó incluso hasta Lusitania, v. Gonçalves, 2007, 407, v. nº 200.

259 CSIR España, 2002, 53. 66. de un taller común ${ }^{260}$. Según se ha demostrado, estos talleres tenían una estrecha relación con Italia ${ }^{261}$, lo que explica el uso del abanico de motivos del mundo grecorromano, consistente en gorgonas, silenos y sátiros, que son precisamente las figuras que aparecen representadas en las piezas citadas ${ }^{262}$. Como las mencionadas imágenes grotescas celtas de La Tène temprana se remontan igualmente a los rostros caricaturescos grecorromanos ${ }^{263}$, la semejanza formal no requiere más explicación, ambas corrientes remontan a la misma fuente.

En analogía con las imágenes de la Alta Andalucía, los presuntos cuernos o coronas de hojas deberían interpretarse más bien como mechones de cabellos peinados hacia lo alto. En el demonio B se ha dejado una especie de bulto o chichón entre los mechones corniformes, que podría ser un hueco para los presuntos cuernos, para el que no se ha encontrado explicación (figura 16). En la parte superior del relieve se intuye un estucado y es posible que el estuco estuviera decorado con pinturas. Asimismo cabe suponer que en esos huecos hubiera algo insertado, por ejemplo, parte de la cabellera (ide metal?). En el demonio A se aprecia un punto de rotura (supuestamente reciente) (figura 15), del que más tarde se retiró el material rocoso. Precisamente fue esta operación, que no puede datarse, en la que solo se mantuvieron los dos mechones exteriores, la que confirió al rostro la apariencia de un personaje cornudo. La prueba de que no puede tratarse de la superficie de fondo original, descrita en lo que antecede, que enmarca el rostro, la aporta el hecho de que el punto de rotura no se encuentra al mismo nivel de la superficie del fondo, sino que penetra mucho más profundamente en la piedra. También en este caso cabe pensar en la inserción de una parte independiente de la cabellera o en un adorno de la cabeza, como en el demonio B. En cualquier caso parece acertada -con razón- la hipótesis de que, en analogía con los ejemplos andaluces, en el demonio $\mathrm{A}$, los mechones que originalmente formaban un peinado alto se extendían prácticamente sobre toda la frente, llegando de oreja a oreja.

260 Se trata de la tumba de los Stlacii en Salaria, v. CSIR España, 2002, 46, Fig. 16, y 58, Fig. 23.

261 CSIR España, 2002, 47.

262 De las piezas descritas se identifica como Gorgo: CSIR España, 2002, $97 n^{\circ}$ 48; como Sileno: CSIR España, 2002, 99, n⿳0 54., 146, v. nº 150; como sátiro: CSIR España, 2002,100 v., $\mathrm{n}^{\mathrm{e}} 56.145 \mathrm{n}^{\mathrm{Q}} 149$.

263 Jacobsthal, 1969, 20. 22. 156. 
El contexto de la función de los dos relieves de Río Tinto debe buscarse también en la arquitectura funeraria. Los bloques en los que aparecen representados los dos demonios solo ofrecen un único punto de vista, como se comprueba al examinar las superficies laterales alisadas y los toscos reversos (figuras 15 y 16), es decir, estaban pensados para ser colocados de forma que solamente se viera el frente. De la necrópolis La Dehesa, en Río Tinto, se conocen cimentaciones rectangulares aplastadas, casi cuadradas, que podrían interpretarse perfectamente como construcciones funerarias tipo torre ${ }^{264}$. No es posible saber si los relieves A y B estaban colocados juntos en un mismo edificio o cada uno en uno distinto. Atendiendo a las diferencias formales (distintos tamaños) y estilísticas descritas, es lógico suponer, en principio, la existencia de dos construcciones.

En este caso se sumaría además una característica común al mencionado contexto de la Alta Andalucía, como es el material utilizado (gossan) y su tratamiento escultórico. Este material es típico de Río Tinto, pues, salvo aquí, no se usaba en ningún otro lugar. En Río Tinto, en cambio, se procesaba en un taller especializado ${ }^{265}$. De esta producción se conocen más de 100 piezas $^{266}$. El taller estuvo activo desde la época flavia hasta mediados del siglo II d.C. y trabajaba fundamentalmente para la necrópolis, a la que suministraba sillares, capiteles, fustes, basas, cupae y sarcófagos para las construcciones funerarias ${ }^{267}$. La fabricación de los relieves con los demonios encaja en este contexto, que también coincide cronológicamente, pues durante algún tiempo, en concreto, hacia finales del siglo I d. C., los talleres de la Alta Andalucía y de Río Tinto estuvieron activos simultáneamente. Es fácil imaginarse que escultores andaluces trabajaron también en Río Tinto. En cuanto la necrópolis más importante de Río Tinto, La Dehesa se caracteriza también por la decoración figurativa de sus tumbas. Con ello se hace cada vez más evidente que tanto en Urium/Río Tinto, en cuanto asentamiento, como en otras localidades mineras de la región ${ }^{268}$, existía

264 Jones, 1980, 154, Fig. 5. Sobre esta necrópolis v. también Pérez Macías, 2009, 359; Pérez Macías y Delgado Domínguez, 2012, 314-316.

265 Delgado Domínguez y Pérez Macías, 2014, 411-414. 266 Pérez Macías, 2009, 352.

267 Pérez Macías, 2009, 351-360.

268 Por ejemplo, el asentamiento de Corta Dehesa en Río Tinto, del que proceden claramente dos estatuas identi- cierto prurito artístico, que había que satisfacer, de equipararse a las ciudades romanas más conocidas de la Bética.

\section{RESUMEN Y CONCLUSIÓN.}

Resumen. La recopilación de las divinidades indígenas del Occidente hispano ofrece una imagen heterogénea. Junto a esculturas interpretadas como grecorromanas, como Endovélico o los demonios de Río Tinto, hay otras que se enmarcan claramente en la tradición celto-romana, como el dios herrero de Vilar de Perdizes, o creaciones propias, como el llamado Vestius Aloniecus. El impulso mediterráneo de producir imágenes de deidades fue asumido por tanto de distinta manera, desembocando en soluciones diferentes. La distancia de las mismas respecto de los monumentos de Roma es evidente. Al mismo tiempo, los monumentos documentan sin duda los inicios hacia una evolución propia en Hispania, que, sin embargo, no consiguió imponerse ante el trasfondo de los modelos romanos mencionados al comienzo, y en lo que respecta a las imágenes de divinidades propias, tampoco llegó a crearse un canon común en el Occidente indoeuropeo de Hispania. El ejemplo de Aelius Fronto en Munigua pone claramente de manifiesto que la iniciativa para crear imágenes de divinidades calificables de indígenas solamente podía provenir del ámbito privado. Según la posición social, el nivel de formación, la procedencia -de la capital, Augusta Emerita, o de la provincia profunda-, el resultado es muy heterogéneo, como cabría esperar.

Dis Pater es un dios del inframundo, esposo de Proserpina, que puede identificarse con Plutón. Anunciaba presagios funestos, provocaba acontecimientos extraordinarios y terremotos, producía vapores pestíferos y se le ofrecían sacrificios de sangre $^{269}$ en forma de animales negros ${ }^{270}$. Arqueológicamente, estas características no han dejado ningún rastro en Munigua y, según parece, tampoco existen. La presencia de la divinidad solo encuentra una explicación en la existencia de las numerosas minas, que durante siglos constituyeron la base económica de la ciudad. Todo el recinto puede cla-

ficadas, con buen fundamento, como Claudio y Livia; sobre otros ejemplos y asentamientos mineros v. Schattner, 2008, 332 s. en: Pérez Macías et al., 2008, 326-332; Pérez Macías, $2009,349$.

269 Sobre los sacrificios de sangre en la Hispania prerromana v. ahora De la Bandera Romero, 2002.

270 Grünhagen, 1976, 231. 
sificarse sin dificultad entre las sacella secondaires, término acuñado por Jean-Charles Balty para designar los santuarios pequeños de importancia secundaria existentes en los foros ${ }^{271}$. Este santuario dedicado a Dis Pater erigido conforme a un diseño arquitectónico es el único que se conoce del mundo romano.

También la cabeza del dios Endovélico debió pertenecer a la imagen de culto del santuario correspondiente. Su calidad es extraordinaria desde todos los puntos de vista para las circunstancias lusitanas, y en el trasfondo de la escultura en la región ocupa sin duda una posición única, acentuada aún más por tratarse de un oráculo, es decir, una forma de culto originaria de Oriente que en Occidente no es muy frecuente. Realmente sorprende encontrar un santuario de estas características en una región tan apartada como la Lusitania central. Quienes acudieran al santuario, entre los que incluso figura un jinete romano, serían sin duda capaces de entender el lenguaje visual, aunque se tratara de un santuario situado en medio del campo, lejos de las ciudades más cercanas, como Augusta Emerita y Ebora ${ }^{272}$. La localización, junto con los materiales y demás hallazgos, apuntan a un donante particular. Como ejemplo de donaciones de este tipo cabe citar el santuario que el senador Calpurnius Rufinus mandó erigir en Panóias, en el norte de Portugal ${ }^{273}$. Por este motivo se tiende a interpretar de la misma manera las imágenes de Vestius Aloniecus y de Sucellus. En una región en la que las representaciones figurativas son muy escasas, donde no hay un arte menor digno de mención ni terracotas, ni estatuillas, ni otras imágenes, ni tampoco la tradición correspondiente, los relieves de Vestius Aloniecus y de Sucellus tuvieron que ejercer una fuerza de atracción enorme. Atendiendo a esta circunstancia, se les debe reconocer un carácter de excepción y ver en ellos imágenes de divinidades. El debate sobre si se trata de imágenes de culto o votivas es preferible dejarlo abierto, pues la transición entre unas y otras

271 Balty, 1993, 91. A la localización de estos santuarios pertenecen también los lugares de culto imperial que, por lo general, se encuentran en el foro o muy cerca del mismo, p. ej. en Narona (Dalmacia) o en Boubon/Kybiratis (resumen Witschel, 2002, 120 s.) o quizá también en la Cestros cílica (Bean y Mitford, 1970, 155-160) y ahora también en Augusta Emerita (Nogales Basarrate, 2008), si bien su finalidad sigue sin estar totalmente clara (Witschel, 2002, 114-117).

272 Recientemente, resumen en Schattner, 2017b, 354-357.

273 Recientemente, resumen en Schattner 2017b, 363-365. es muy fluida. En este contexto resulta igualmente interesante el hecho de que se trata de relieves y no de esculturas de bulto redondo. Ambos géneros tienen tradición en el arte prerromano de la región ${ }^{274}$. En el arte grecorromano, las imágenes de los diosesson, por lo general, esculturas exentas ${ }^{275}$. Mientras que las esculturas de bulto redondo o exentas están separadas de la pared o de otro soporte, el relieve está integrado en una plancha de piedra que actúa de soporte. No obstante, de esta característica no se puede sacar ninguna conclusión sobre el emplazamiento original. El hecho de que en todos los casos se trate de divinidades masculinas se corresponde con la idea general de que, en cuanto a la tradición iconográfica, en el ámbito indoeuropeo de Hispania predominan las deidades masculinas, mientras que en el entorno ibérico predominan las femeninas.

Los creadores de imágenes de divinidades del noroeste hispano en ningún momento recurrieron a su tradición iconográfica, sino que sucumbieron a la fuerza de atracción de la imaginería grecorromana, que les ofrecía soluciones mucho más adecuadas para su tarea. Incluso los guerreros galaico-lusitanos que parecen tan indígenas muestran influencias mediterráneas, como el contraposto que se apunta en alguna de las estatuas ${ }^{276}$.

Tanto la población como las instituciones del Imperio romano estaban obligadas a posicionarse en el marco establecido. Esa obligación generó no solo fuerzas creativas, sino también el impulso de crear imágenes antropomórficas de las divinidades. En un territorio carente de una tradición indígena de tal índole, la mirada en busca de modelos ha de traspasar los límites regionales. Todas las imágenes de divinidades descritas en este artículo (tabla 1) fueron esculpidas en la época imperial, en un momento en el que ya se había producido el impacto y en Hispania aún perduraba la correspondiente difusión de los modelos romanos. Las imágenes con raíces en la tradición de Roma, mencionadas al principio, dan suficiente testimonio de ello.

A modo de conclusión, las observaciones siguientes parecen interesantes:

Tanto en la cabeza de Endovélico como en los demonios de Río Tinto se recurre, de forma más o menos clara, a la tradición iconográfica grecorromana convencional.

274 Calo Lourido, 1993/94; Calo, 1994; Schattner, 2003. 275 Sobre la ambivalencia v. la, Atenea Partenos, Nick, 1997 y Nick, 2002.

276 Schattner, 2003. 
Algo distinto ocurre en el caso del dios herrero de Vilar de Perdizes, pues es evidente que detrás del mismo se esconden representaciones de Sucellus (con contornos difuminados). Este dios era venerado sobre todo en las provincias septentrionales del imperio, como la Galia, Recia, Germania y Britania, lo que prueba que la mirada se dirigió también a las otras provincias. Es evidente que dentro del marco regulador cabían también relaciones transversales entre las provincias.

Finalmente, hay que señalar encarecidamente que con la imagen de Vestius Aloniecus se creó, al parecer, una iconografía de la nada, lo que es posible aplicar también, aunque de forma restrictiva, al caballo del Dis Pater de Munigua. Se trata sin duda de un acto intelectual que se manifiesta en la forma material presentada.

\section{BiBLIOGRAFÍA}

Abascal Palazón, J.M. y Alföldy, G. (2005), Inscripciones romanas de la provincia de Toledo (siglos I-III), Bibliotheca archaeologica hispana, 42, Madrid.

Acuña Castroviejo, F. (1974), "Notas sobre la morfología y la decoración en las aras y las estelas de Galicia en época romana”, Studia Archaeologi$c a, 32,17-31$.

F. Acuña Castroviejo, F. y P. Rodríguez García, P. (2000), "La plástica funeraria en la Galicia romana”, Actas de la III Reunión sobre escultura romana en Hispania ( P. León Alonso y T. Nogales Basarrate, Eds.), Córdoba, 197-209. Alarcão, J. de (1974), Portugal romano, Lisboa.

Alarcão, J. de (1988), Roman Portugal, Gazetteer II, Warminster.

Alfayé Villa, S. (1963), Santuarios y rituales en la Hispania Céltica, BAR International Series, 1963, Oxford.

Alfayé Villa, S. (2013), "Sobre iconografía y teonimia en el noroeste peninsular", Paleohispanica, 13, 189-208.

Almagro-Gorbea, M. (1994), "El urbanismo en la Hispania céltica. Castros y oppida en la Península”, Castros y oppida en Extremadura (M. Almagro-Gorbea y A. M. Martín Arija, Eds.), Complutum extra, 4, 13-75.

Almagro-Gorbea, M. (1996), Ideología y poder en Tartessos y el Mundo Ibérico, Discurso de ingreso en la Real Academia de la Historia, leído el día 17 de noviembre de 1996, Madrid.
Almagro-Gorbea, M. 2006), "Ideología ecuestre en la hispania prerromana”, El caballo en el mundo prerromano (M. Barril Vicente y F. Quesada Sanz, Eds.), Gladius, 25, 59-94.

Almeida, C.A. de (1974), Escavações no Monte Mozinho 1974, Peñafiel.

Almeida, C.A. de (1980), "O templo de Mozinho e o seu conjunto”, Portugalia, 1, 51-56.

Alonso Rodríguez, M., Luzón Nogué, J.Mª y Mañas Romero, I (2014), "El santuario de Tajo Montero en Estepa, Sevilla”, Santuarios suburbanos y del territorio de las ciudades romanas (J. Mangas Manjarrés y M. A. Novillo López, Eds.), Madrid, 535-548.

Altenhöfer, E. (2007), "Die Cella des Dioskurentempels von Cori”, Römische Mitteilungen, 113, 373-397.

Álvarez-Ossorio, F. (1941), Catálogo de los exvotos de bronce ibéricos, Madrid.

Andreae, B. (2012), Römische Kunst von Augustus bis Constantin, Maguncia.

Aranegui Gascó, C. y Prados, L. (1998), “Die Heiligtümer. Heiligtümer - die Begegnung mit der Gottheit”, Die Iberer, 151-161.

Alves de Araújo, I. (1999), "Vestio Lonieco e os Argonautas", Congresso de proto-história europeia, Actas. Centenário da morte de Francisco Martins Sarmento (A. Amaro das Neves, Coord.), Guimarães, 223-261.

Ayerbe Vélez, R., Barrientos Vera, y F. Palma García-Eds.- (2009), El foro de Augusta Emerita. Génesis y evolución de sus recintos monumentales, Anejos de Archivo Español de Arqueología, 53, Mérida.

Bakalakis, G. (1973), "Vorlage und Interpretation von römischen Kunstdenkmälern in Thessaloniki”, Archäologischen Anzeiger, 88, 671-684.

Balil Illana, A. (1960), "Plástica provincial en la España romana”, Revista de Guimarães, 70, 107-131.

Balil Illana, A. (1974), "Sobre las esculturas de época romana en Galicia”, A Ranuccio Bianchi-Bandinelli sus amigos y discipulos españoles, Studia Archaeologica, 32, 43-48.

Balil Illana 1978A. Balil Illana, A. (1978), Esculturas romanas de la Península Ibérica I, Studia Archaeologica, 51, Valladolid.

Balil Illana, A. (1979a), Esculturas romanas de la Península Ibérica II, Studia Archaeologica 54, Valladolid. 
Balil Illana, A. (1979b), Esculturas romanas de la Península Ibérica III, Studia Archaeologica, 60, Valladolid.

Balil Illana, A. (1981), Esculturas romanas de la Península Ibérica IV, Studia Archaeologica, 68, Valladolid.

Balil Illana, A. (1982), Esculturas romanas de la Península Ibérica V, Studia Archaeologica, 71, Valladolid.

Balil Illana, A. (1983), Esculturas romanas de la Península Ibérica VI, Studia Archaeologica, 73, Valladolid.

Balty, J.C. (1993), "Le centre civique des villes romaines et ses espaces politiques et administratifs", La ciudad en el mundo romano (X. Dupré i Raventós, Eds.), Actas del Congreso Internacional de Arqueología Clásica, Tarragona, 91-99.

De la Bandera Romero, $M^{a}$ L. (2002), "Rituales de origen oriental entre las comunidades tartesias: el sacrificio de animales", Ex oriente lux. Las religiones orientales antiguas en la Península Ibérica (E. Ferrer Albelda, Ed.), Spal Monografías II, 1141-158.

Bean, G. y Mitford, B.M. (1970), Journeys in Rough Cilicia 1964-1968, Viena.

M. Belén, Ma y Escacena, J.L. (2002), "La imagen de la divinidad en el mundo tartésico", Ex oriente lux. Las religiones orientales antiguas en la Península Ibérica (E. Ferrer Albelda, Ed.), Spal Monografías II, 159-184.

Beltrán Lloris, F. -Ed.- (1995a), Roma y el nacimiento de la cultura epigráfica en occidente, Actas del Coloquio Roma y las Primeras Culturas Epigráficas del Occidente Mediterráneo, siglos II a. E. - I d. E., Zaragoza.

Beltrán Lloris, F. (1995b),"La escritura en la frontera. Inscripciones y cultura epigráfica en el Valle Medio del Ebro", Roma y el nacimiento de la cultura epigráfica en occidente (F. Beltrán Lloris, Ed.), Zaragoza, 169-196.

Beltrán Lloris, F. (2012), "Roma y la epigrafía ibérica sobre piedra del Nordeste peninsular”, $P a$ laeohispanica, 12, 9-30.

Beltrán Lloris, M. (1976), Arqueología e historia de las ciudades antiguas del Cabezo de Alcalá de Azaila, Teruel, Monografías Arqueológicas, 19, Zaragoza.

Beltrán Lloris, M. (1996), Los íberos en Aragón, Colección «Mariano de Pano y Ruata», 11, Zaragoza.
Beltrán Lloris, M. (2000), Azaila, estado de la cuestión en el año 2013, Caesaraugusta, 83, 1-536.

Bendala Galán, M. y Quesada Sanz, F. (1995), “El caballo en la Bética romana", Al-Andalus y el caballo (P. de la Torre, Ed.), El Legado Andalusí, Barcelona, 51-65.

Benoît, F. (1950), Les mythes de l'outretombe. Le cavalier à l'anguipède et l'écuyère Epona, Collection Latomus, 3, Brüssel.

Benoît, F. (1954), L’heroïsation équestre, Publication des Annales de la Faculté des lettres, Aix-en-Provence, Nouv. Série, 7, Aix-en-Provence.

Benoît, F. (1959, Mars et Mercure. Nouvelles recherches sur l'interprétation gauloise des divinités romaines, Pubblications des Annales de la Faculté des lettres, Nov. Série, 25, Aix-en-Provence.

Bergemann, J. (1990), Römische Reiterstatuen. Ehrendenkmäler im öffentlichen Bereich, Beiträge zur Erschließung hellenistischer und kaiserzeitlicher Skulptur und Architektur, 11, Maguncia.

Bergmann, M. (1998), Die Strahlen der Herrscher, Maguncia.

Birkhan, H. (1999), Kelten. Bilder ihrer Kultur Celts. Images of their culture, Viena.

Blanco Freijeiro, A. (1949), "Dioses bicornes”, Cuadernos Gallegos, 4, 429-431.

Blanco Freijeiro, A. (1957), "Exvoto con escena de sacrificio", Revista de Guimarães, 67, 499-516.

Blanco Freijeiro, A. (1962), “Antigüedades de Riotinto", Zephyrus, 13, 31-45.

Blanco Freijeiro, A. (1975), "Ein Kopf des Vulkan in Córdoba", Madrider Mitteilungen, 16, 263-266.

Blanco Freijeiro, A. y Luzón Nogué, J.Mª (1966), "Mineros antiguos españoles", Archivo Español de Arqueología, 39, 73-88.

Blanco Freijeiro, A. Luzón Nogué, J.M ${ }^{a}$ y Ruiz Mata, D. (1970), Excavaciones arqueológicas en el Cerro Salomón (Riotinto, Huelva), Anales de la Universidad Hispalense. Serie Filosofía y Letras, 4, Sevilla.

Blázquez Martínez, J. Mª (1957), “Aportaciones al estudio de las religiones primitivas de España”, Archivo Español de Arqueología, 30, 15-86.

Blázquez Martínez, J. Maㅗ (1962), Religiones primitivas de Hispania, 1 . Fuentes literarias y epigráficas, Biblioteca de la Escuela Española 
de Historia y Arqueología en Roma, 14, Madrid.

Blázquez Martínez, J. Mª (1970), “Las religiones indígenas del área noroeste de la Península Ibérica en relación con Roma", Legio VII Gemina (J. Caro Baroja, Ed.),León, 63-77.

Blázquez Martínez, J.Mํㅗㄹ (1973), “Die Althispanier”, Götter und Mythen im alten Europa 2 (H.-W. Haussig, Ed.), Stuttgart , 705-828.

Blázquez Martínez, J. Mª (1975), Diccionario de las religiones prerromanas de Hispania, Colección Colegio Universitario, 6, Madrid.

Blázquez Martínez, J.Mำ (1977), Imagen y mito. Estudios sobre religiones mediterráneas $e$ ibéricas, Madrid.

Blázquez Martínez, J.Mª (2001), Religiones, ritos y creencias funerarias de la Hispania prerromana, Colección Historia Biblioteca Nueva, Madrid.

Blech, M. (1981), "Esculturas de Tajo Montero (Estepa). Una interpretación iconográfica”, La religión romana en Hispania, Madrid, 97-106.

Blech, M. (1993a), "Quellheiligtum Fonte do Ídolo“, en Trillmich, W., Hauschild, Th., M. Blech, M., Niemeyer, H.G., A. Nünnerich-Asmus, A. y Kreilinger, U., Hispania Antiqua, Denkmälerder Römerzeit, Maguncia, $362 \mathrm{~s}$. Tab. 147.

Blech, M. (1993b), "Kopf des Endovellicus", en Trillmich, W., Hauschild, Th., M. Blech, M., Niemeyer, H.G., A. Nünnerich-Asmus, A. y Kreilinger, U., Hispania Antiqua, Denkmäler der Römerzeit, Maguncia, 396 s., Tab. 197.

Blech, M. (2001a), "Aufgezäumte Pferdestatue", en M. Blech, M. Koch y M. Kunst, Hispania Antiqua. Denkmäler der Frühzeit, Maguncia, 621.

Blech, M. (2001b), "Jugendlicher Reiter", en M. Blech, M. Koch y M. Kunst, Hispania Antiqua. Denkmäler der Frühzeit, Maguncia, 627.

Blech, M. (2001c), "Grabcippus“, en M. Blech, M. Koch y M. Kunst, Hispania Antiqua. Denkmäler der Frühzeit, Maguncia, 628, Taf. 227.

Blech, M. y Blech, M. (2002/03), "El Vaso de los Dragones de la necrópolis de Hoya de Santa Ana (Chinchilla, Albacete)", Homenaje a la Dra. Dña. Encarnación Ruano, Boletín de la Asociación Española de Amigos de la Arqueología, 42, 245-263.

Brommer, F. ( 1972), " Vulcanus in Spanien“, Ma- drider Mitteilungen, 12,147-152.

Boucher, S. ( 1983), "L'image de Mercure en Gaule",La patrie gauloise d'Agrippa au VIème siècle, Lyon, 57-69.

Bouza Brey, F. (1944), "Las aras romanas de Lourizán, una nueva deidad galaica”, Museo de Pontevedra, 3, 201-206.

Caballos Rufino, A. (2001), "Latinidad y municipalización de Hispania bajo los Flavios, estatuto y normativa", Mainake, 23, 101-120.

Cabré, J. (1925), "Los bronzes de Azaila”, Archivo Español de Arte y Arqueología, 3, 297-315.

Calo Lourido, F. (1991), "Relieve de Vestio Alonieco”, Galicia no tempo. Ausstellungskatalog Monasterio de San Martiño Pinario, Santiago de Compostela, 114.

Calo Lourido, F. (1993/94), "Arte castrexa, escultura e decoración arquitectónica”, Cuadernos Gallegos, 106, 75-110.

Calo Lourido, F. (1994), A plástica da cultura castrexa galego-portuguesa, La Coruña.

Carballo, J. (1948), "Las estelas gigantes de Cantabria”, Cuadernos Gallegos, 3, 5-21.

Cardozo, M. (1971), Catálogo do Museu de Martins Sarmento, Guimarães.

Cardozo, M. (1973), "Breves considerações sobre a escultura primitive da Lusitânia pré- e protohistórica”, Cuadernos Gallegos, 28, 153-160.

Carvalho, H. P. Abreu de (1992), A escultura romana em Portugal, Ponta Delgada, Manuscrito fotocopiado.

Carvalho, H. P. Abreu de (1993/94), "Contribuição para o estudo da escultura funerária de época romana encontrada em Portugal”, Cadernos de Arqueología, 10/11, 65-90.

Catalogue (2007), Le cheval et la danseuse, à la redécouverte du trésor de Neuvy-en-Sullias, Ausstellungskatalog Orléans, Musée des Beaux-Arts, 13. März bis 26. August 2007und Musée départamental de Bavay, 15. Januar bis 15. Juni 2008 (Paris 2007).

Cerrillo, E. y Cruz, M. (1993), "La plástica indígena y el impacto romano en la Lusitania”, Actas de la I Reunión sobre escultura romana en Hispania (T. Nogales Basarrate, Ed.), 159-178.

Chapa Brunet, T. (1980), La escultura zoomorfa ibérica en piedra, Madrid.

Chapa Brunet, T. (1986), "Influjos griegos en la escultura zoomorfa ibérica”, Iberia graeca, 2, 61-310. 
CILA SE, González Fernández, J.(1991-1996), Corpus de inscripciones latinas de Andalucía II Sevilla. Tomo I La Vega (Hispalis). Tomo II La Vega (Itálica). Tomo III La Campiña. Tomo IV. El Aljarafe, Sierra Norte, Sierra Sur, Sevilla.

Coarelli, F. (2011), Römische Kunst von den Anfängen bis zur mittleren Republik, Maguncia.

Collantes de Terán, F. y Fernández-Chicarro, C. (1972-74), "Epigrafía de Munigua", Archivo Español de Arqueología, 45-47, 337-410.

Corot, H. (1925), "Le cheval-enseigne de Guerchy au Musée d'Auxerre”, Revue des musées et collections archéologiques, 1, 6-9.

Corzo Pérez, S., Pastor Muñoz, M. y Stylow, A. (2007), "Betatun, la primera divinidad ibérica identificada”, Palaeohispanica, 7, 251-262.

Mattern, M. (1999), Die römischen Steindenkmäler des Stadtgebietes von Wiesbaden und der Limesstrecke zwischen Marienfels und Zugmantel, Corpus signorum Imperii Romani, Deutschland II, 11, Maguncia.

Bauchhenss, G. (1990), Germania inferior, Bonn und Umgebung. Militärische Grabdenkmäler, Corpus signorum Imperii Romani, Deutschland III, 1, Bonn 1978.

Souza, V. de (1990), Portugal I, Corpus signorum Imperii Romani, Coimbra.

Baena del Alcázar, L. y Beltrán Fortes, J. (2002), Esculturas romanas de la provincia de Jaén, Corpus signorum Imperii Romani, España I, 2, Murcia.

Neukorn, C. (2002), Das übrige helvetische Gebiet, Antiqua 34, Corpus signorum Imperii Romani, Schweiz I,7 , Basel.

Cuadrado Díaz, E. (1950), Excavaciones en el santuario ibérico del Cigarralejo, Mula/Murcia, Informes y memorias 21, Madrid.

Debal, J. (1974), Les Gaulois en Orléanais. Des invasions celtiques à l'occupation romaine, Bulletin de la Société Archéologique et Historique de l'Orléanais, 2, Orléans.

Delgado Domínguez, A. -Coord.- ( 2006), Catálogo del Museo de Riotinto, Sevilla.

Delgado Domínguez, A. (2014), "Lucernae Uriensia, la colección lychnológica de Riotinto (Huelva, España)", Cadernos do Museu da Lucerna, I, Castro Verde, 45-100.

Delgado Domínguez, A. y Pérez Macías, J.A. (2014), "Artífices e industrias auxiliares en las minas hispanas”, Artifices idóneos. Artesanos, talleres y manufacturas en Hispania (M. Bustamante Álvarez y D. Bernal Casasola, Eds.), Anejos de Archivo Español de Arqueología, 71, 389-419.

Delgado Domínguez, A., Moreno Bolaños, A., Pérez Macías, J.A., Gemio del Río, G. y Regalado Ortega, Mํㅡㄹ C. (2011), "Minería de hierro en Riotinto (Huelva)", Boletín Geológico y Minero, 122, 311-324.

Delgado Domínguez, A., Regalado Ortega, Mª C. y Lagares, J. (2015), "Reutilización de elementos constructivos romanos de Gossan transportado, Cuenca Minera de Riotinto (Huelva, España), VII Encuentro de Arqueología del Suroeste Peninsular (N. Medina Rosales, Coord.), Arcohe, 739-755.

Díaz y Díaz, M.C. (1983), "Sobre la implantación del latín en la sociedad galaico-romana”,Estudos de cultura castrexa e de historia antiga de Galicia (G. Pereira Menaut, Eds.), Cursos y congresos de la Universidad de Santiago de Compostela, 30, Santiago de Compostela, 283-293.

Die Iberer (1998), Ausstellungskatalog, Paris, Barcelona, Bonn 15. Mai - 23. August 1998 (o. O. 1998)

Domergue, C. (1987), Catalogue des mines et des fonderies antiques de la péninsule Ibérique, Publications de la Casa de Velázquez, Série Archéologie, 8, Madrid.

Domergue, C. (1990), Les mines de la Péninsule Ibérique dans l'Antiquité romaine, Collection de l'Ecole française de Rome 127, Roma.

Duval, P.M. (1977/2009), Les celtes, Paris (1977 reimpresión en 2009).

Edmondson, J.C., Nogales Basarrate, T. y Trillmich, W. (2001), Imagen y memoria, monumentos funerarios con retratos en la colonia Augusta Emerita, Monografías emeritenses, 6, Bibliotheca Archaeologica Hispana, 10, Madrid.

Escacena, J.C. (2002), "Dioses, toros y altares. Un templo para Baal en la antigua desembocadura del Guadalquivir”, Ex oriente lux. Las religiones orientales antiguas en la Península Ibérica (E. Ferrer Albelda, Ed.), Spal Monografías, 2, Sevilla, 33-75.

Espérandieu, E. (1907-1981), Recueil general des bas-reliefs, Statues et bustes de la Gaule romaine, Paris.

Espérandieu, E. (1931/1965), Complément du Re- 
cueil general des bas-reliefs, Statues et bustes de la Gaule romaine, Ridgewood.

Fabião, C., Guerra, A. y Schattner, Th G. (2013), "A investigação em torno do Santuário de S. Miguel da Mota. O ponto de situação", Cadernos de Endovélico, 1, 2013, 65-98.

Fabião, C., Guerra, A. y Schattner, Th G. (e.p.), Das Heiligtum des deus Endovellicus in São Miguel da Mota (Alandroal/Portugal), Forschungen und Grabungen 2002 bis 2012, Madrider Beitrage, 38/1.

Fellague, D. (2016), "Nouveautés sur une trentaine de pieces sculptées conserves à Lyon", La sculpture romaine en occident, nouveaux regards (V. Gaggadis-Robin y P. Picard, Eds.), Arles, 299-310.

Fernández Gómez, F. (2003), "Los caballos de Luque (Córdoba)", El caballo en la antigua Iberia, estudios sobre los équidos en la Edad del Hierro (F. Quesada Sanz y M. Zamora Merchán, Eds.), Bibliotheca Archaeologica Hispana, 19, Madrid, 21-61.

Fernández Götz, M. A. (2009), “¿Celtas en Andalucía? Mirada historiográfica sobre una problemática (casi) olvidada”, Spal, 16, 173-185.

Fernández Maroto, D., Vélez Rivas, J. y J. Pérez Avilés, J. (2007), "La cerámica estampillada ibérica de tipo figurativo del Cerro de las Cabezas (Valdepeñas)", Arte Ibérico en la España mediterránea (L. Abad Casal y J. A. Soler Díaz, Eds.), Alicante, 211-227.

Fernández Uriel, P. (998), "Fases de la conquista romana e inícios del asentamiento", Hispania, el legado de Roma.En el Año de Trajano (M. Almagro-Gorbea y J. M $\mathrm{M}^{\mathrm{a}}$ Alvarez Martínez, Eds.), Zaragoza, 51-64.

Fischer, M. (2009), "Sculpture in Roman Palestine. Import and Local Production. An Overview", Les ateliers de sculpture régionaux: techniques, styles et iconographie (V. Gaggadis-Robin, Ed.), Arles, 401-415.

Fischer, Th. (2001), "Definition", Die römischen Provinzen. Eine Einführung in ihre Archäologie (Th. Fischer, Ed.), Stuttgart, 13-15.

Fischer, Th. (2010), "Provinzialrömische Archäologie", Mitteilungen des Deutschen Archäologen-Verbandes, 41, 46-49.

Gabelmann, H. (1972), "Die Typen der römischen Grabstelen am Rhein", Bonner Jahrbücher, 172, 65-140.
Gamo Pazos, E. (2012), Corpus de inscripciones latinas de la provincia de Guadalajara, Guadalajara.

Garcia, D. (2006), "Religion et société. La Gaule méridionale", Religion et société en Gaule (Chr. Goudineau, Ed.), Paris, 135-164.

García-Bellido, Ma ${ }^{\mathrm{a}}$ P. (2002/03), "Los gestos de poder divino en la imaginería”, Cuadernos de Prehistoria y Arqueología de la Universidadd Autónoma de Madrid, 28/29, 227-240.

García y Bellido, A. (1971), Iberische Kunst in Spanien, Maguncia.

Garnier, J. Fr. (1992), "Excisum au moment de la conquête romaine (Eysses à Villeneuve-sur-Lot, Lot-et-Garonne)", Les Celtes, la Garonne, et les Pays Aquitains (R. Boudet, Ed.), Agen, 102-104.

Garrido, E., A., Mar, R. y Martins, M. (2008), A Fonte do Ídolo, análise, interpretação e reconstituição do santuário, Bracara Augusta escavações arqueológicas, 4, Braga.

Gimeno Pascual, H. (2003), "La sociedad de Munigua a través de sus inscripciones”, Epigrafía y sociedad en Hispania durante el Alto Imperio. Estructuras y relaciones sociales (S. Armani y B. Hurlet-Martineau, Eds.), Alcalá de Henares, 177-192.

Gimeno Pascual, H. (2008), "Paisajes epigráficos en el espacio romano de la Comunidad de Castilla-La Mancha”, La romanización en el territorio de Castilla-La Mancha (G. Carrasco Serrano, coord.), Cuenca, 261-338.

Goldbeck , V. (2015), Fora augusta. Das Augustusforum und seine Rezeption im Westen des Imperium Romanum, Eikoniká, 5, Regensburg.

Gómez-Pantoja, J. (1997), Hispania Epigraphica, 7,25, Nr. 51

Gómez-Pantoja, J. (2008), Hispania Epigraphica, 17,44 Nr. 74

Gonçalves, L.J. (2007), Escultura romana em Portugal. Uma arte do quotidiano, Studia Lusitana, 2, Mérida.

Gonçalves, L.J. (2013), "Esculturas do Santuário do Endovélico”, Cadernos de Endovélico, 1, $16-50$.

González Alcalde, J. (1997), "Simbología de la diosa Tanit en representaciones cerámicas ibéricas”, Quaderns de prehistòria $i$ arqueologia de Castelló, 18, 329-343. 
González Ruibal, A. (2003), "Camino del tiempo. Orígenes protohistóricos de la Vía XIX”, $L a$ rouco, 3, 157-167.

Goudineau, Chr. -Ed.- (2006), Religion et société en Gaule, Paris.

Goudineau, Chr. y Verdier, P. (2006), "Religion et science", Religion et société en Gaule (Chr. Goudineau, Ed.), Paris, 27-77.

Grünhagen, W. (1976), "Eine Weihung für Dis Pater in Munigua“, Madrider Mitteilungen, 17, 226-237.

Guerra, A., Schattner, Th. G., Fabião, C. y Almeida, R. (2005), "São Miguel da Mota (Alandroal/ Portugal) 2002. Bericht über die Ausgrabungen im Heiligtum des Endovelicus“, Madrider Mitteilungen, 46, 184-234.

Gusi Jener, F. (1997), "Lugares sagrados, divinidades, cultos y rituales en el levante de Iberia", Quaderns de prehistòria $i$ arqueologia de Castelló, 18, 171-219.

Hauschild, Th. (1986), "Munigua. Ausgrabungen an der Stützmauer des Forums - 1985“, Madrider Mitteilungen, 27, 325-343.

Hernando, Ma del R. (2008), Hispania Epigraphica, 17, 82 Nr. 123.

Hesberg, H. von (2007), "Die Statuengruppe im Tempel der Dioskuren von Cori. Bemerkungen zum Aufstellungskontext von Kultbildern in spätrepublikanischer Zeit“, Römische Mitteilungen, 113, 443-460.

Hoz, J. de (1995, "Panorama provisional de la epigrafía rupestre paleohispánica”, Saxa scripta, inscripciones en roca (A. Rodríguez Colmenero y L. Gasperini, Eds.), Larouco Anejo, 2, A Coruña, 9-33.

Ioppolo, G. (1967), "La tavola delle unità di misura nel mercato augusteo di Leptis Magna”, Quaderni di archeologia della, 5, 1967, 89-98.

Jacobsthal, P. (1969), Early Celtic Art , 2(1969)

Jaeggi, O. (1999), Der Hellenismus auf der Iberischen Halbinsel. Studien zur iberischen Kunst und Kultur, das Beispiel eines Rezeptionsvorgangs, Iberia Archaeologica, 1, Maguncia.

Jones, D.G.B. (1980), “The Roman Mine at Río Tinto", Journal Roman Studies, 70, 146-165.

Kent, J., Overbeck, B. y Stylow, A.U. (1973), Die römische Münze, München.

Kleiner, D.E.E. (1987), Roman imperial funerary altars with portraits, Archaeologica, 62,
Roma.

Klöckner, A.(2012), " Von der Anschauung zur Anbetung - Götterbilder im antiken Griechenland", Gießener Universitätsblätter, 45, 2941.

Kobusch, Ph. (2014), Die Grabbauten im römischen Hispanien. Zur kulturellen Prägung der Sepulkralarchitektur, Tübinger Archäologische Forschungen, 14,Rahden/Westf.

Koppel, E.M. (1999), "La escultura ideal romana”, En el año de Trajano. Hispania, El legado de Roma (M. Almagro-Gorbea y J. Mª Alvarez Martínez, Eds.), Zaragoza, 303-311.

Krämer , W. (1989), "Das eiserne Ross von Manching, Fragmente einer mittellatènezeitlichen Pferdeplastik", Germania, 67, 519-539.

Krug, A. (2006), "Munigua - der Anfang vom Ende. Die Aussage der Bronzeskulpturen und anderer Funde", Madrider Mitteilungen, 47, 152-168.

Kunze, Chr.(2008), "Zwischen Griechenland und Rom : Das "antike Rokoko« und die veränderte Funktion von Skulptur in späthellenistischer Zeit", Original und Kopie. Formen und Konzepte der Nachahmung in der antiken Kunst (K. Junker y A. Stähli, Eds.), Wiesbaden, 77-108.

Lambrino, S. (1951), "Le dieu lusitanien Endovellicus", Bulletin des Études Portugaises de L'Institut Français au Portugal, Nouvelle série, 15, 93-147.

Lantier, R. (1939), La tombe royale de Sutton Hoo (Suffolk), Revue Archeologique, 6 Ser. 14.

Laubscher, H.P. (1982), Fischer und Landleute. Studien zur hellenistischen Genreplastik, Maguncia.

León Alonso, P. (1981), "Plástica ibérica e iberorromana”, La baja época de la cultura ibérica, Madrid, 183-202.

LIMC IV, C. Letta, "Helios/Sol", Lexicon iconographicum mythologiae classicae IV, 1 (Zürich und München 1988), 592-625 s.

LIMC VII, A. Nagy, "Sucellus", Lexicon iconographicum mythologiae classicae VII, 2 (Zürich und München 1994), 578-580 ss.

López Cuevillas, F. (1951), "Esculturas zoomorfas y antropomorfas de la cultura de los castros", Cuadernos Gallegos, 6, 177-203.

López Cuevillas, F. (1953), La civilización céltica en Galicia, Santiago de Compostela. 
López Cuevillas, F. (1979), "Prehistoria”, Historia de Galiza, 3 (R. Otero Pedrayo, Ed.), Madrid, 7-538.

López Monteagudo, G. (1977), “Apéndice: Los celtas de la Península Ibérica”, Los celtas (V. Kruta, Ed.), Colección EDAF universitaria, 13, Madrid.

MacMullen, R. (1982), "The Epigraphic Habit in the Roman Empire", The American Journal of Philology, 103/3, 233-246.

Maestro Zaldivar, E.M. (1989), Cerámica ibérica decorada con figura humana, Monografías Arqueológicas, 31, Zaragoza.

Maniquet, Chr. (2005), "Découverte à Tintignac (Corrèze, F). Un dépôt exceptionnel d'objets gaulois", Instrumentum, 21, 37-38.

Maniquet, Chr. (2008), "Le dépôt cultuel du sanctuaire gaulois de Tintignac à Naves (Corrèze)", Gallia, 65, 273-326.

Maniquet, Chr. (2016), “Tintignac (Naves, dépt de la Corréze). Un imposant lieu de culte en terrioire lémovice, mais pour quelles divinités?", Présence des divinités et des cultes dans les villes et les agglomérations secondaires de la Gaule romaine et des régions voisines, du Ier siècle avant notre ère au IVer siècle de notre ère (R. Bedon y H. Mavéraud-Tardiveau, Eds.), Caesarodunum 47/48, 131-172.

Marco Simón, F. (1999), Deis Equeunu(bo), Pueblos, lenguas y escrituras en la Hispania prerromana (F. Villar Liébana y F. Beltrán Lloris, Eds.), Actas del VII Coloquio sobre lenguas y culturas paleohispánicas, Zaragoza, 481-490.

Marco Simón, F. (2003), "Signa deorum, comparación y contexto histórico en hispania y Galia", Arqueología e iconografía. Indagar en las imágenes (T. Tortosa y J. A. Santos, eds.), Bibliotheca Italica, 26, Roma, 121-136.

Matos, J.L. de (1995), Inventário do Museu Nacional de Arqueología, Colecção de Escultura Romana, Lisboa.

Meid, W. (1994), Celtiberian inscriptions, Budapest.

Méniel, P. (2006), "Religion et sacrifices d'animaux", Religion et société en Gaule (Chr. Goudineau, Ed.), Paris, 165-176.

Megaw, R. y Megaw, V.(1990), Celtic art. From its beginnings to the book of kells, London.

Mierse, W.E. (1999), Temples and towns in Roman Iberia: the social and architectural dynamics of sanctuary designs from the third century B.C. to the third century A.D., Berkeley.

Moneo, T. (2003), Religio Ibérica. Santuarios, ritos y divinidades, siglos VII-I A.C., Bibliotheca Archaeologica Hispana, 20, Madrid.

Müller, U.A. (1990), "Das Pferd in der griechisch-keltischen Frühgeschichte", Helvetia Archeologica, 21, 153-165.

Nash, W.G. (1904), The Rio Tinto Mine, its History and Romance, London.

Nick, G. (1997), "Die Athena-Parthenos“, Ein griechisches Kultbild,Kult und Kultbauten auf der Akropolis (W. Hoepfner, Ed.), Schriften des Seminars für klassische Archäologie der Freien Universität Berlin, Berlin, 22-24.

Nick, G. (2002), Die Athena Parthenos: Studien zum griechischen Kultbild und seiner Rezeption, Athenische Abteilung, 19, Maguncia.

Nicolini, G. (1968), "Gestes et attitudes cultuels des figurines de bronze ibériques", Melanges de la Casa Velázquez, 4, 27-44.

Nicolini, G. (1977), Bronces ibéricos, Barcelona.

Nogales Basarrate, T. (1997), El retrato privado en Augusta Emerita,Colección arte-arqueología, 13, Badajoz.

Nogales Basarrate, T. (2008), "Rómulo en el Augusteum del foro colonial emeritense", Le due patrie acquisite. Studi di archeologia dedicati a Walter Trillmich (E. La Rocca, P. León y C. Parisi Presicce. Eds.), Roma, 301-312.

Nony, C. J. (1969), "Une nouvelle interprétationdes bronzes d'Azaila”, Melanges de la Casa de Velázquez, 5, 5-30.

Olivares Pedreño, J.C. (2002), Los dioses de la Hispania céltica, Bibliotheca Archaeologica Hispana, 15, Anejos de Lucentum, 7, Madrid.

Olmos Romera, R. (1992), "Religiosidad e ideología ibérica en el marco del Mediterráneo", Religiosidad y vida cotidiana en la España ibérica, 3 (D. Vaquerizo Gil, Coord.), Seminario Fons Mellaria Córdoba, Córdoba, 11-45.

Pereira Menaut, G. (1995), " Epigrafía "política« y primeras culturas epigráficas en el noroeste de la P. Ibérica", (1995), Roma y el nacimiento de la cultura epigráfica en occidente (F. Beltrán Lloris, Ed.), Zaragoza, 293-326.

Pérez Macías, J.A., Schattner, Th. G., Gimeno Pascual, H. y Stylow, A.U. (2008), "Claudius und Livia in Urium? Ein Statuenfund im Erzrevier von Riotinto (Prov. Huelva)“, Madrider Mitteilungen, 49, 302-340. 
Pérez Macías, J.A. (2009), "Lapicidinae ad Metalla”, Marmora Hispana. Explotación y uso de los materiales pétreos en la Hispania romana (J. Beltrán Fortes y T. Nogales Basarrate, Eds.), Colección Hispania Antigua, Serie arqueológica, 2, Roma, 339-364.

Pérez Macías, J.A. y Delgado Domínguez, A. (2012), "Las cupae de Riotinto (Huelva)", Las cupae hispanas, orígen, difusion, uso, tipología (J. Andreu Pintado, Ed.), Monografías «Los Bañales», 1, Zaragoza, 303-341.

Pfuhl, E. y Möbius, H. (1979), Die ostgriechischen Grabreliefs, Maguncia.

Prados Torreira, L. (1991), “Dos exvotos anatómicos del santuario ibérico de Collado de los Jardines (Sta. Elena, Jaén)", Trabajos de Prehistoria, 48, 313-332.

Quesada Sanz, F. y Gabaldón Martínez, M. del M. (2008), “¿Hipolatría, epifanía, protección de un bien valioso? En torno al papel rreligioso de los équidos en la Protohistoria peninsular”, De dioses y bestias. Animales y religion en el mundo antiguo (E. Ferrer Albelda, J. Mazuelos Pérez y, J. L. Escacena Carrasco, Coords.), Spal Monografías, 11, Sevilla, 144-162.

Ramos Fernández, R. (1993), "El caballo como divinidad ibérica", Studia paleohispanica et indogermanica J. Untermann ab amicis hispanis oblata (I.J. Adiego Lajara, J. Siles y J. Velaza, Eds.), Barcelona, 267-273.

Recio Veganzones, A. (1994), "Relieve ibérico funerario con caballo de Las Peñuelas (Martos)", Homenaje a José María Blázquez, 2 (J. Alvar Ezquerra y J. Mangas Manjarrés, Eds.), Madrid , 467-491.

Reinach, S. (1894), Antiquités nationales. Description raisonnée du musée de Saint-Germain-en-Laye. 2 Bronzes figures de la Gaule romaine, Paris.

Ribeiro, J. -Ed.- (2002), Religiões da Lusitânia, Loquuntur saxa, Lisboa.

Ribeiro, J. (2002a), "Métopa de friso com representação ritual”, Religiões da Lusitânia, Loquuntur saxa (J. Ribeiro, ed.), Lisboa, 375, Nr. 32.

Ribeiro, J. (2002b), "Cabeça do deus Endovélico", Religiões da Lusitânia, Loquuntur saxa (J. Ribeiro, ed.), Lisboa, 381 Nr. 31.

Robert, L. (1961), Épigraphie. Les épigraphies et l'épigraphie grecque et romaine, L'histoire et ses methodes (Ch. Samaran, Ed.), Encyclopédie de la Pléiade, 11, Paris, 453-502 [=Opera minora selecta. Epigraphie et antiquités grecques 5 (Amsterdam 1989) 65-102].

Rodà, I. (1990), "La escultura romana importada en Hispania Citerior”, El comercio marítimo romano en el Mediterráneo occidental , Barcelona, 291-312.

Rodríguez Colmenero, A. (1977), Galicia meridional romana, Publicaciones de la Universidad de Deusto. Historia 1, Bilbao.

Rodríguez Colmenero, A. (1991a), "Deusa da fecundidade”, Larouco, 1, 157.

Rodríguez Colmenero, A. (1991b), Guerreros y topónimos en la Gallaecia romana, nuevas aportaciones y revisión de otras, Anejos de Larouco, 5, Lugo.

Rodríguez Colmenero, A. (1993), "Escultura en relieve y bulto Redondo", Galicia, Arte (F. Rodríguez Iglesias, Eds.), La Coruña, 373-475.

Rodríguez Oliva, P. (1983), "Exvotos ibéricos con relieves de équidos de la Vega Granadina”, XVI Congreso nacional de arqueología (F. Peregrín Pardo y J. R. Andérica Frías, Coords.), Murcia, 751-761.

Rodríguez Oliva, P. (1996), "Las primeras manifestaciones de la escultura romana en la Hispania meridional”, Actas de la II Reunión sobre escultura romana en Hispania (J. Massó y P. Sada, Eds.), Tarragona, 13-30.

Rodríguez Oliva, P. (1998), "La monumentalización en las ciudades del sur de Hispania entre la República y el Imperio”, Italia e Hispania en la crisis de la República romana (J. Mangas Manjarrés, Ed.), Actas del III Congreso Hispano-Italiano, Madrid, 313-337.

Roscher, W.H. (1884-1890), AusführlichesLexikon der griechischen und römischen $M y$ thologie, Leipzig.

RPC I 1992, A. Burnett ,A., Amandry, M. y P. P. Ripollès Alegre, P.P. (1992), Roman provincial coinage I. From the death of Caesar to the death of Vitellius, Londres.

Rueda Galán, C. (2011), Territorio, culto e iconografía en los santuarios iberos del Alto Guadalquivir (ss. IV a.n.e. - I. d.n.e.), Jaén.

Ruiz-Nicoli, B. (2009), "Die Sammlung römischer Kaiserporträts im Museo Arqueológico Nacional“, Madrider Mitteilungen, 50, 296-339.

Schade, K. (2015), "Göttlicher Schein und fabulierendes Beiwerk. Götterstatuen des 2. bis 4 . Jahrhunderts n. Chr. ", Römische Götterbilder 
der mittleren und späten Kaiserzeit (D. Boschung y A. Schäfer, Eds.), Morphomata , 22, Paderborn, 159-195.

Schattner, Th. G. (2003), "Stilistische und formale Beobachtungen an den Kriegerstatuen", Madrider Mitteilungen, 44, 127-149.

Schattner, Th. G. (2008), "Die Statuen", en «Claudius und Livia in Urium? Ein Statuenfund im Erzrevier von Riotinto (Prov. Huelva)», Madrider Mitteilungen, 49, 302-340.

Schattner, Th. G. (2011), "El periodo orientalizante en Riotinto", I Congreso de Historia, Patrimonio minero y Turismo cultural (J. A. Pérez Macías, A. Delgado Domínguez, J. M. Pérez López y F. J. García Delgado, Eds.), Huelva, 75-93.

Schattner, Th. G. (2012), "Kurze Bemerkung zu den Figurenfriesen und Prozessionsdarstellungen auf westhispanischen Denkmälern", $M a$ drider Mitteilungen, 53, 403-428.

Schattner, Th. G. (2013a), "Die Romanisierung einheimischer Heiligtümer im Westen der Iberischen Halbinsel unter besonderer Berücksichtigung von Votiv und Ritual", Sanktuar und Ritual. Heilige Plätze im archäologischen Befund, 10 (I. Gerlach y D. Raue, Eds.), Rahden, 393-415.

Schattner, Th. G. (2013b), " iWo in Munigua tagte der Senat?", Madrider Mitteilungen, 54, 348-370.

Schattner, Th. G. (2015), "Pre-Roman and Roman Sanctuaries of the Hispanic West and their Rituals, an Archaeological Contribution to the Linguistic Division of the Country", Der antike Mensch im Spannungsfeld zwischen Ritual und Magie (Chr. Zinko y M. Zinko, Eds.), 1 Grazer Symposium zur indogermanischen Altertumskunde Graz, Leykam, 341-375.

Schattner, Th. G., Azcárraga Cámara, S. , Brose, K., Bouresh, B., Gutiérrez, M., Krug, A. ,Martini, W., Ruipérez, H., Schäffler y R. Scholz, R. (2017), Munigua/Spanien. Die Arbeiten der Jahre 2015 und 2016., Forschungsberichte Des Dai 2017 Faszikel 1, 128-142.

(https://www.dainst.org/publikationen/e-publikationen/e-forschungsberichte, consultado el 11.2.2018).

Schattner, Th. G. (2017b), "Projet d'étude des cultes et des sanctuaires de l'ouest de la péninsule ibérique à l'époque romaine, réflexions sur les nouvelles fondations", Quand naissent les dieux.
Fondation des sanctuaires antiques. Motivations, agents, lieux (S. Agusta-Boularot, S. Huber y W. van Andringa, Eds.), Collection de l'École française de Rome, 534, Roma/Atenas, 351-381.

Schattner, Th.G. (2018), "El panteón de las divinidades de Munigua: Arqueología, Epigrafía, Topografía”, In Roma nata (D. Dopico y M. Villanueva, Eds., Lugo, 73-100.

Schattner, Th, (e.p. 1), "Wege zur Teilhabe. Archäologische Bemerkungen zu Bild und Text auf nordwest-hispanischen Denkmälern in der Kaiserzeit“, Kontinuität und Diskontinuität, Lokale Traditionen und römische Herrschaft im Wandel (Th. Schattner y D. Vieweger, Eds.).

Schattner, Th. G. (e.p. 2), "Das Forum", Mulva, $V I I$ (Th. G. Schattner, ed.).

Schattner, Th.G., Ovejero Zappino, G. y Pérez Macías, J.A. (2004), "Zur Metallgewinnung von Munigua, ein Vorbericht", Madrider Mitteilungen, 45, 351-370.

Schattner, Th., Guerra, A. y Fabião, C. (2008), "La cariátide de São Miguel da Mota, Alandroal, y su relación con las cariátides de Mérida”, Escultura Romana en Hispania, 5 (J. M. Noguera Celdrán y E. Conde Guerri, Eds.), Murcia, 697-730.

Schattner, Th., Guerra, A. y Fabião, C. (2009), “Die Idealköpfe des Endovellicus - eine Zwischenbilanz", Les ateliers de sculpture régionaux. Techniques, styles et iconographie (V. Gaggadis-Robin, A. Hermary, M. Reddé y C. Sintes, Eds.), Xe. Colloque International sur l'art provincial romain, Arles, 483-494.

Scheid, J. (2014), "Opferaltar und Weihaltar in Rom und Italien", Römische Weihealtäre im Kontext (A. Busch y A. Schäfer, Eds.), Friedberg, 27-35.

Selzer, W. (1988), Römische Steindenkmäler. Maguncia in römischer Zeit. Katalog zur Sammlung in der Steinhalle, Katalogreihe zu den Abteilungen und Sammlungen, Landesmuseum Maguncia, 1, Maguncia.

Settis, S. (1973), "Esedra e ninfeo nella terminologia architettonica del mondo romano. Dall'età repubblicana alla tarda antichità", Aufstieg und Niedergang der römischen Welt, 14, 661-754.

Sievers, S. (1991), "Armes et sanctuaires à Manching", Les santuaires celtiques et le monde méditerranéen (J.L. Brunaux, Ed.), $\mathrm{Pa}-$ 
rís, 146-155.

Silva, A. da (2007), A cultura castreja no Noroeste de Portugal, Paços de Ferreira.

Soeiro, T. (1984), "Monte Mózinho. Apontamentos sobre a ocupação entre Sousa e Tâmega em época romana", Penafiel, 3. Ser., 1, 5-323.

Soeiro, T. (1998), Monte Mozinho, sitio arqueológico, Penafiel.

Tarradell, M. (1969), Arte romano en España, Barcelona.

Thiemann, E. (1959), Hellenistische Vatergottheiten. Das Bild des bärtigen Gottes in der nachklassischen Kunst, Orbis antiquus, 14, Münster.

Thüngen, S.(1994), Die frei stehende griechische Exedra, Maguncia.

Tranoy , A. (977), “A propos des "Callaeci« de Pline. Epigraphie et peuplement”, Bracara Augusta, 31, 225-233.

Tranoy, A. (1981), La Galice romaine. Recherches sur le nord-ouest de la Péninsule Ibérique dans l'antiquité, Publications du Centre Pierre Paris, Collection de la Maison des Pays Ibériques, 7, París.

Trillmich, W., Hauschild, Th., M. Blech, M., Niemeyer, H.G., A. Nünnerich-Asmus, A. y Kreilinger, U., (1993), Hispania Antiqua, Denkmäler der Römerzeit, Maguncia.

Trillmich, W. (1993), "Hispanien und Rom aus der Sicht Roms und Hispaniens", Hispania Antiqua, Denkmäler der Römerzeit Trillmich (W. Hauschild, Th., M. Blech, M., Niemeyer, H.G., A. Nünnerich-Asmus, A. y U. Kreilinger, Eds.), Maguncia, 41-69

Trillmich, W. (1994), "Colonia Augusta Emerita, die Hauptstadt von Lusitanien", Stadtbild und Ideologie. Die Monumentalisierung hispanischer Städte zwischen Republik und Kaiserzeit (W. Trillmich y P. Zanker, Eds.), Abhandlungen der Bayerischen Akademie der Wissenschaften. Philosophisch-Historische Klasse n. F. 103, Veröffentlichungen der Kommission zur Erforschung des antiken Städtewesens, Múnich, 299-316.

Trillmich, W. (1994), “Aspekte der "Augustus-Nachfolge" des Kaisers Claudius”, Die Regierungszeit des Kaisers Claudius (41-54 n. Chr.). Umbruch oder Episode?, (V. M. Strocka, Ed.), Maguncia, 69-89.

Trillmich,W. (2001), "De altar a tabernáculo. Evolución tipológica y artística de un modelo de representación funeraria”, 2001), Imagen y memoria, monumentos funerarios con retratos en la colonia Augusta Emerita (J.C. Edmondson, T. Nogales Basarrate y W. Trillmich, Eds.), Monografías emeritenses, 6, Bibliotheca Archaeologica Hispana, 10, Madrid, 19-35.

Untermann, J. (1961), Sprachräume und Sprachbewegungen im vorrömischen Hispanien, Wiesbaden.

Untermann, J. (1975), Monumenta Linguarum Hispanicarum I. Die Münzlegenden, Wiesbaden.

Varagnac, A. (1956), L'art gaulois,La nuit des temps, 4, Yonne.

Vasconcellos, J. Leite de (1905), Religiões da Lusitânia II, Lisboa.

Vázquez Varela, J.M. (1996), "A guerra e mailas súas imaxes na Idade do Bronce de Galicia”, $L a$ rouco, $2,33-45$.

Vedder, U. (2001), Grabsteine mit Porträt in Augusta Emerita (Lusitania). Zur Rezeption stadtrömischer Sepulkralkunst in einer Provinzhauptstadt, Kölner Studien zur Archäologie der römischen Provinzen, 5, Rahden/Westf.

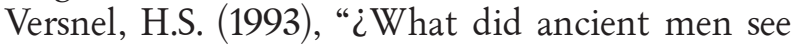
when he saw a god?, Some Reflections on Graeco-Roman Epiphany”, Effigies dei. Essays on the History of Religions (D. van der Plas, Ed.), Leiden, 42-55

Vidal, J.C. (2016), "Interpretació ibérica de dos teònims preromans del nord-est peninsular", Revista d'Arqueología del Ponent, 26, 195-204

Vollenweider, W. L. (1972-74), Die Porträtgemmen der römischen Republik, Maguncia.

Wesenberg, B. (1975/76), "Zum metrologischen Relief in Oxford", Marburger Winckelmann-Programm, 1975/76, 15-22.

Williams, W. (1932), Notes on Ancient History and Museum Exhibits at Rio Tinto, Inventario inédito, Archivo Fundación Riotinto.

Witschel, C. (2002), "Zum Problem der Identifizierung von munizipalen Kaiserkultstätten”, Klio, 84, 114-124.

Zanker, P. (1995), Die Maske des Sokrates. Das Bild des Intellektuellen in der antiken Kunst, Múnich. 
